\title{
2. SITE 382: NASHVILLE SEAMOUNT - VOLCANISM ALONG THE EASTERN NEW ENGLAND SEAMOUNT CHAIN
}

\author{
The Shipboard Scientific Party ${ }^{1}$
}

\author{
SITE DATA \\ Position: $34^{\circ} 25.04^{\prime} \mathrm{N}, 56^{\circ} 32.25^{\prime} \mathrm{W}$ \\ Water Depth (PDR, sea level): 5526 meters \\ Water Depth (PDR, rig floor): 5536 meters \\ Bottom Felt at (rig floor): 5537 meters \\ Penetration: 520.5 meters \\ Number of Holes: 1 \\ Number of Cores: 25 \\ Total Length Cored: 232.2 meters \\ Total Core Recovered: 163.4 meters \\ Core Recovery: 70.4 per cent \\ Oldest Sediment Cored: Volcaniclastic breccia \\ Bottoms at: 520.5 meters \\ Age: Lower Campanian or older \\ Velocity: $3.4-4.2 \mathrm{~km} / \mathrm{sec}$ \\ Nature of Basement: Volcaniclastic breccia \\ Encountered at: $385.3-520.5$ meters \\ Velocity: $3.4-4.2 \mathrm{~km} / \mathrm{sec}$
}

Date Occupied: $1358 \mathrm{Z}$ hours, 5 July 1975

Date Departed: 0830Z hours, 9 July 1975

Time on Site: 3 days, 18 hours, 32 minutes

Principal Results: The sedimentary section above the buried eastern flank of Nashville Seamount was sampled to a subbottom depth of 520.5 meters. The hole bottomed in coarse volcaniclastic breccia attributed to volcanism on Nashville Seamount. Slow progress in penetrating the breccia and consideration of time restrictions led us to abandon the hole at this level.

The sedimentary sequence at Site $\mathbf{3 8 2}$ is summarized as follows (with average sediment accumulation rates in par-

\footnotetext{
${ }^{1}$ Brian E. Tucholke (Co-Chief Scientist), Lamont-Doherty Geological Observatory, Palisades, New York; Peter R. Vogt (CoChief Scientist), Naval Research Laboratory, Washington, D.C.; Kenneth R. Demars, University of Rhode Island, Kingston, Rhode Island (now at: University of Delaware, Newark, Delaware); Jon S. Galehouse, San Francisco State University, San Francisco, California; Robert L. Houghton, Woods Hole Oceanographic Institution, Woods Hole, Massachusetts (now at: University of Alberta, Edmonton, Alberta, Canada); Ansis Kaneps, Deep Sea Drilling Project, Scripps Institution of Oceanography, La Jolla, California; John W. Kendrick, Shell Development Company, Houston, Texas; I. N. McCave, University of East Anglia, Norwich, England; Charles L. McNulty, University of Texas, Arlington, Texas; Ivar O. Murdmaa, P. P. Shirshov Institute of Oceanology, Moscow, USSR; Hisatake Okada, Lamont-Doherty Geological Observatory, Palisades, New York (now at: Yamagata University, Yamagata, Japan); and Peter Rothe, Mineralogisch Petrografisches Institut der Universität Heidelberg, Heidelberg, Federal Republic of Germany (now at: Geographisches Institut der Universität Mannheim, Mannheim, Federal Republic of Germany).
}

entheses): 0 to 232 meters sub-bottom depth, Quaternary and upper Pliocene silty clays, silts, and sands $(\sim 120$ $\mathrm{m} / \mathrm{m} . \mathrm{y}$.); 232-352 meters, mid-Pliocene to lower Miocene hemipelagic clays ( $\sim 6 \mathrm{~m} / \mathrm{m} . \mathrm{y}.) ; 352-385$ meters, upper to lower Campanian varicolored (volcanogenic) silty clays and marly nannofossil ooze; 385-520.5 meters, lower Campanian volcanogenic clay, silty clay, marly limestone, and volcaniclastic breccia overlying lower Campanian volcanogenic claystones over breccia $(\sim 39 \mathrm{~m} / \mathrm{m} . \mathrm{y}$.). The upper Campanian and lower Miocene are separated by a hiatus of some 50 m.y. and a short $(0.5$ m.y. $)$ hiatus may be present in the upper Pliocene. The rapidly deposited Quaternary silty clays represent a succession of distal turbidites that suggest that the Sohm Abyssal Plain was not developed in this region until mid-Pliocene. The 50-m.y. hiatus probably reflects some combination of current erosion and local slumping off the seamount's flanks. Volcanic activity on Nashville Seamount was in progress in the early Campanian and had waned or perhaps terminated by late Campanian time. This volcanism helps explain the relatively high accumulation rate (at least $39 \mathrm{~m} / \mathrm{m} . \mathrm{y}$.) during this interval. High vesicularity of basaltic clasts indicates that the summit of Nashville Seamount was less than 0.5 to $1 \mathrm{~km}$ below sea level during the early Campanian. Finer grained deposits deposited during the late Campanian suggest a waning of volcanic activity, if in fact the material was not introduced from more distant sources. Numerous Campanian to lower Maestrichtian ash horizons encountered $450 \mathrm{~km}$ away at DSDP Site 10 may in part have been derived from Nashville Seamount. The existence of two breccia zones, separated by finer grained sediments, suggests that seamount volcanism was episodic; the interval between brecciaproducing episodes probably did not exceed a few million years.

The basalt clasts exhibit varying degrees of vesicularity and alteration, and probably represent samples from various eruptive events. The basalts are highly alkalic and relatively enriched in light rare earths. Radiometric ages on the lower breccia range from $49 \pm 4 \mathrm{~m}$.y. to $88.3 \pm 5.7$ m.y. Our best estimate for the time of the principal, edificebuilding volcanism is $80-85$ m.y.B.P.

Although the "original" oceanic basement was not reached, we estimate that about 10 to $13 \mathrm{~m}$.y. elapsed between formation of basement and the lowermost cored breccia. Measured along the flow lines of plate motion, Site 382 lies midway between anomaly $M-4$ and DSDP Site 10 . The former is believed to date from 115-120 m.y.B.P. and the latter (lower to mid-Campanian) from 75-80 m.y.B.P. If the Late Cretaceous to Eocene sedimentation rate (2 $\mathrm{m} / \mathrm{m} . \mathrm{y}$.) measured at Site 9 also applies at Site 382, a minimum of 35 to 45 meters of sediment may be present between the lower breccia and original oceanic basement.

\section{BACKGROUND AND OBJECTIVES}

Two Leg 43 drill sites were proposed for the New England (Kelvin) seamounts, which comprise one of the few conspicuously linear seamount chains in the North 
Atlantic. The primary objectives of these holes were to determine the age of volcanic activity at each site, to sample the volcanic material, to date the original oceanic basement, if feasible, and to reconstruct the history of sedimentation.

If the seamount chain was formed as a result of the northwest motion of the North America plate over a fixed mantle hot spot (Coney, 1971; Morgan, 1973; Vogt, 1973), the seamounts should become progressively older from southeast to northwest. Sites initially chosen (Nashville and Gosnold seamounts) are spaced roughly $650 \mathrm{~km}$ apart (Figure 1), and at rates of the order 1 to $10 \mathrm{~cm} / \mathrm{yr}$ for the differential movement between plate and mantle, there should be a 65 to $6.5 \mathrm{~m}$.y. age difference between volcanism at these sites. Because the ship encountered strong currents and because of time limitations, Vogel Seamount was drilled instead of Gosnold Seamount. Vogel Seamount is only about 450 $\mathrm{km}$ from Nashville, and the age difference to be tested for was reduced to 45 to 4.5 m.y. A major objective of Leg 43 was to determine whether there is a significant age difference between Nashville and Vogel seamounts and to estimate its magnitude.

Age gradients conforming to the mantle hot spot hypothesis (Morgan, 1973) are now reasonably well established for a number of volcanic island/seamount chains in the Pacific, most notably the Hawaiian Ridge (Jackson, 1976). However, three drill sites and two dredges along the Line Islands chain (Leg 17, Site 165; Leg 33, Sites 315 and 316) suggest roughly simultaneous activity (80-85 m.y.B.P.) along most of the chain (Saito and Ozima, 1976). Should this be corroborated by additional dating, it would mean that some linear volcanic seamount chains, perhaps including the Kelvin seamounts, could have formed by processes other than plate motion over a mantle hot spot. However, there is also evidence from some supposedly hot-spot generated igneous trails (e.g., the Yellowstone/Snake River volcanics) that only the beginning of volcanism at each site is time-transgressive as predicted by the hot-spot model (Suppe et al., 1975). Once formed, a volcano may continue to be active. Thus the Line Islands drill site data (Saito and Ozima, 1976) do not necessarily disprove a hot-spot mechanism, as only the late stages of volcanism were dated. However, if the lifetime of a typical Pacific volcano is less than one million years (Duncan and McDougall, 1974), a simultaneous volcanic event is indicated in the case of the Line Islands chain.

Several hypotheses that do not involve hot spots for the Kelvin chain also have been proposed. Drake et al. (1968) and Uchupi et al. (1970) suggested that the seamounts erupted along the trace of a "Kelvin Fault" or " $40^{\circ} \mathrm{N}$ Fault" that constitutes a seaward extension of a Paleozoic or older structural lineament in the Appalachians. Although the crust under the entire seamount chain probably dates from the Jurassic to Cretaceous, it is still possible that an older structure became reactivated and a fracture extended seaward into already formed oceanic crust, thus creating a line of weakness along which volcanoes could form. A broad belt of recent seismicity lies along an imaginary extension of the
Kelvin chain into New England and southeastern Canada, following the trend of the White Mountain magma series, and this suggests that a "line of weakness" is still active (Sbar and Sykes, 1973; Keen, 1974). Some have suggested that this magmatism is the continental extension of the seamount chain. However, the seamount chain itself is not seismically active and Cretaceous and Tertiary strata on the continental shelf (Garrison, 1970) which are in line with the chain (Keen, 1974) appear undeformed. There is no distinct evidence for faulting of upper Cenozoic sediments in the area of the seamount chain, but the deeper Mesozoic sequence is poorly resolved in profiler data and may contain undetected offsets. The fact that the Jurassic-midCretaceous ocean crust lies generally 500 to 1000 meters deeper on the north side of the seamounts (west of the " $J$-anomaly") suggests that the chain may lie along a fault boundary or flexure whose movement has been primarily vertical.

Le Pichon and Fox (1971) also suggest that the seamounts erupted along an early transform fault. Upon reconstructing the early North Atlantic, they find that the Kelvin seamounts are nearly in a line with the Canary Islands (actually, there is a $150-\mathrm{km}$ misfit). However, Canary Islands volcanism may be only Miocene and younger (Leg 41, Site 369), whereas the Kelvin seamounts are almost certainly older (Uchupi et al., 1970; Vogt, 1973). Therefore, if any significance is attached to the approximate alignment of these two features, it would mean that both groups of volcanoes were controlled by the same older zone of weakness, presumably a transform fault (Le Pichon and Fox, 1971). If the New England seamounts erupted along a fault, no prediction can be made as to age gradients along the chain, and volcanism could have been simultaneous and/or episodic.

An aeromagnetic survey showed that the Late Jurassic to Early Cretaceous Keathley Sequence of magnetic anomalies is more or less continuous through the area of the New England seamounts, and offsets along possible transform faults are relatively minor (Vogt, 1973). Combining an aeromagnetic survey north of the seamounts (Vogt et al., 1970) with surface-ship data over the seamount chain itself (Walczak, 1963), Vogt (1973) suggested that the Keathley Sequence executes a bend northeast of the chain; only the $J$-anomaly $(M-0-M-2)$ could be traced through the complex magnetic field generated by the seamounts. This anomaly probably has a right lateral offset of about $25 \mathrm{~km}$ near $37^{\circ} \mathrm{N}$, $59.5^{\circ} \mathrm{W}$ (fig. 8 of Vogt, 1973). Presumably, the other Keathley lineations show a similarly small offset. These observations do not support significant horizontal offsets implied in the "fault control" hypotheses of Drake et al. (1968), Uchupi et al. (1970), Le Pichon and Fox (1971), and Sbar and Sykes (1973). However, vertical movements are not ruled out. It may also be that the location and spacing of individual seamounts within the chain, as well as the elongate shape of some, can be explained by preferential volcanism along pre-existing fractures whose spacing is of the order of the plate thickness (Vogt, 1974). 


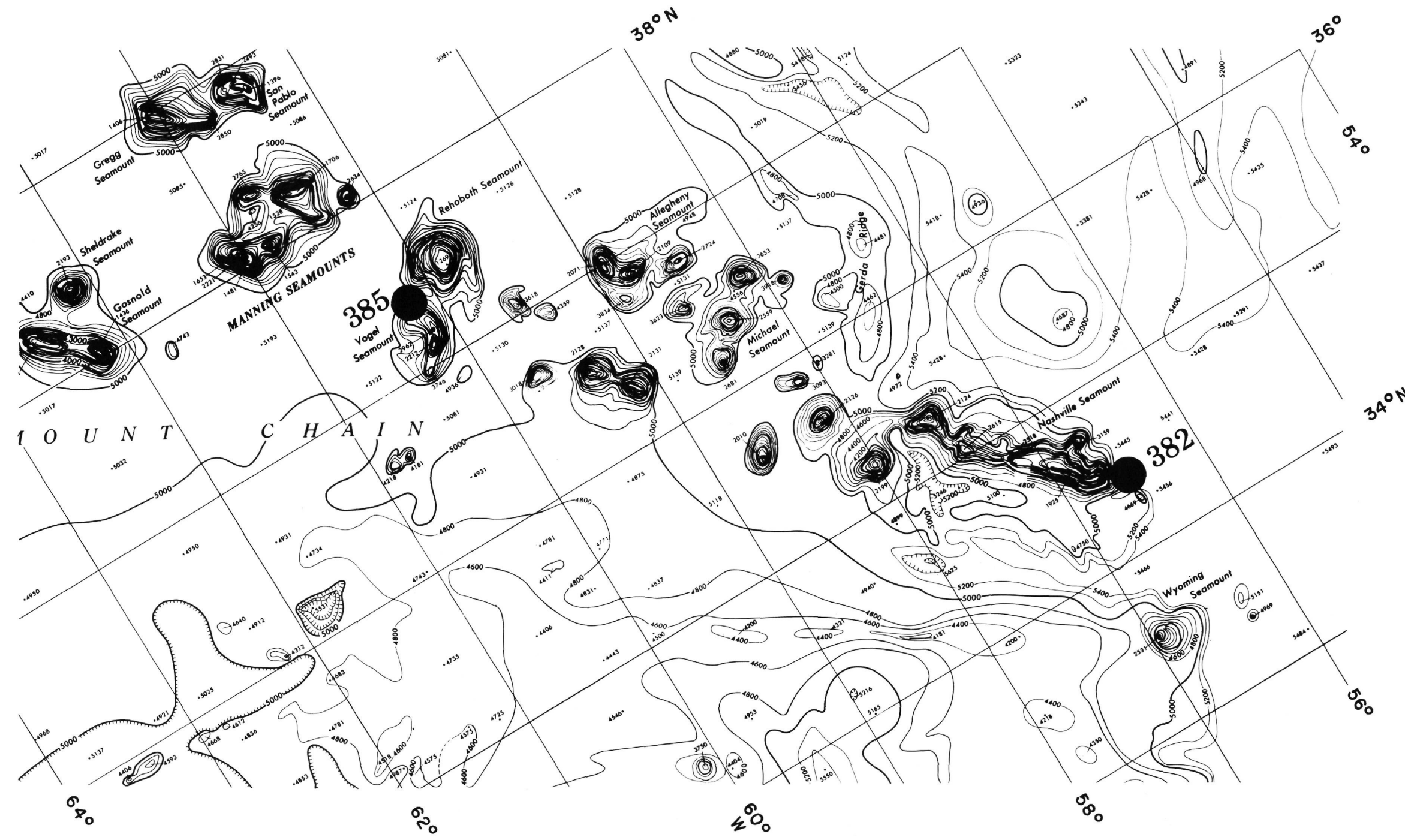

Figure 1. Bathymetry of the southeastern part of the New England seamount chain showing locations of Sites 382 and 385. Depths in uncorrected meters. 
The drill sites planned along the seamount chain were thus intended to determine the age and character of the igneous activity and to sample the sedimentary sequences in the vicinity of the seamounts. Both proposed sites are located over the buried flanks of the seamounts, as was necessary to spud in the drill string. The absence of significant sediment caps (except for algal reefs capping Mytilus and Bear seamounts at the northwestern end of the seamount chain) is probably due to slumping and current erosion.

The potential recovery of relatively unaltered fragments or phenocrysts from the volcaniclastic aprons offered possibilities for absolute (radiometric) age dating and for geochemical comparison with other possible "hot spots" (Schilling, 1973). It was hoped that paleontological dating of sediment interbedded with ash or other volcaniclastic debris would establish the age of the volcanic activity. For example, ash horizons evidently associated with volcanism on the Canary and Cape Verde islands were cored and dated during Leg 2 (Site 12, $300 \mathrm{~km} \mathrm{NNW}$ of Cape Verde) and Leg 41 (Sites 368, $200 \mathrm{~km}$ ENE of Sal, Cape Verde; Site 369, $200 \mathrm{~km} \mathrm{SSE}$ of Canary Island). The Miocene date on the ash cored at these sites is consistent with the age of most intense volcanism as determined for the island volcanics. When volcaniclastics in the archipelagic apron of Midway Island were cored on Leg 32 (Site 311), however, they were found to predate by $10 \mathrm{~m} . \mathrm{y}$. (Oligocene) the midMiocene age of the basalt recovered from below Midway atoll and dated by K/Ar methods.

A further advantage in drilling to the side of a seamount is that the basinal sediment sequence and original basaltic basement can be sampled. The Horizon- $A$ complex (Tucholke, this volume) and Horizon $\beta$ can be traced northward to the seamount chain, although Horizon $\beta$ probably does not exist along the southeastern one-third of the seamount chain because the ocean crust there postdates the probable age of the reflector. Although Horizons $A^{C}$ and (?) $A^{*}$ locally approach the southern side of the seamounts, sediment moats and drifts caused by current activity complicate the acoustic stratigraphy in the immediate area of the seamounts. Stratified sediment ponds that presumably are outliers of the Sohm Abyssal Plain have filled some of the moats surrounding the seamounts.

Nashville is the southeasternmost seamount of the Kelvin chain, and according to the hot-spot hypothesis it is predicted to be the youngest (Figure 1). The elongate shape of this seamount suggests (1) a chain of coalesced volcanoes emplaced along a fracture or (2) a series of fissure eruptions. The southeast trend of the seamount may have been controlled by an inactive transform fault (Vogt, 1974). Although the summit of Nashville Seamount rises to less than 2000 meters below sea level and appears relatively smooth and level on bathymetric charts, the detailed summit topography is rough. An ALVIN dive on the crest showed no evidence of past emergence. However, the high vesicularity of basalts sampled by ALVIN suggests extrusion in relatively shallow water (Heirtzler et al., 1974; Houghton and Ballard, in preparation).
Nashville Seamount lies along the northeast edge of a broader (100 $\mathrm{km}$ wide) bathymetric rise that has the same trend as the seamount chain (Walczak, 1963). The origin of this broader rise is unknown, although it may be in part related to a rise of the original (pre-seamount) basement. Contour charts of total sediment thickness (Ewing et al., 1973) suggests that the ridge is at least in part a sediment bulge. Portions of the Sohm Abyssal Plain almost completely surround this "Nashville rise" (Horn et al., 1971; Keen, 1974).

Seismic reflection profiles crossing the 5.5 -km-deep Sohm Abyssal Plain east and northeast of Nashville Seamount show an average sediment thickness of $0.6 \mathrm{sec}$ reflection time $(0.6 \mathrm{~km}$ at a nominal velocity of 2 $\mathrm{km} / \mathrm{sec}$ ). Average basement depth in the basin is about $7.8 \mathrm{sec}$, but within $50 \mathrm{~km}$ of the seamount the average basement depth appears to be well over $8 \mathrm{sec}$, possibly reflecting downwarp of the lithospheric plate in response to the volcanic load. The abyssal-plain sediments have buried most of the original basement topography, although a few basement peaks still project above the plain. There are also outcrops of a mostly buried sedimentary unit that is acoustically nonlaminated. These outcrops are generally centered around basement highs. Although Horizons $A^{C}$ and $A^{*}$ are observed $100 \mathrm{~km}$ and more southwest of Site 382, they cannot be identified on profiles near Nashville Seamount. Possible fault scarps were observed on Nashville Seamount during the ALVIN dive (Houghton and Ballard, in preparation), but no faults are observed in the adjacent sedimentary section.

Nashville Seamount is barren of sediment except for a 50-meter-thick patch (possibly a side echo) visible on the Vema-2207 reference profile (Figure 2). Near Site 382 , a $0.5-\mathrm{km}$-thick lens of acoustically nonlaminated sediment lies on the lowermost flanks of the seamount. The lens pinches out upslope at about $6.7 \mathrm{sec}$ water depth; it has an irregular upper surface, and at least in its upper part it may be a deposit of slumped pelagic material. The lens is continuous with nonlaminated sediments underlying turbidites in the adjacent basin and it has a similar thickness. This suggests that at least the lower part of the lens is older pelagic material (postvolcanic but pre-turbidite), rather than a recent slump deposit.

Below the non-laminated "pelagic" unit at Site $\mathbf{3 8 2}$ lies an opaque sloping reflector that is the continuation of the seamount's flank. Its high reflectivity, shallow depth, and continuity with the seamount flank suggested that the reflector is material derived from the seamount.

Coring at Site 382 was intended to determine the ages and contact relationships of the turbidites, pelagic sediments, and the volcanic apron. Further drilling through possible prevolcanic sediment and into the original oceanic basement was also planned if time permitted.

\section{OPERATIONS}

Our original plan to drill the first hole of Leg 43 on the $J$-Anomaly Ridge under the Sohm Abyssal Plain 


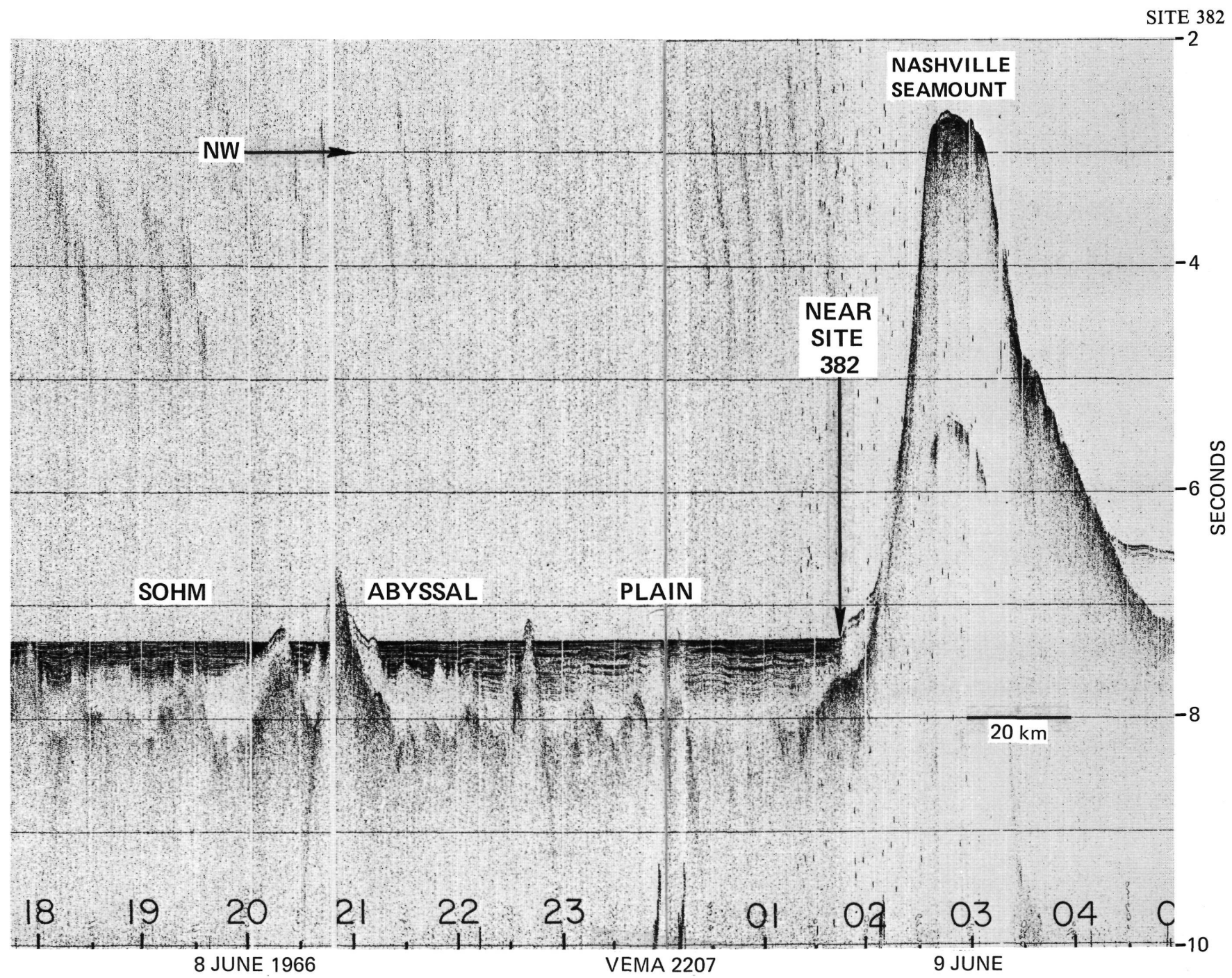

Figure 2. Vema 2207 reference profile near Site 382. Location is in Figure 3. Inaccuracies in position of the pre-satellite navigation Vema track probably account for the features which are different from the Challenger profile (Figure 4).

$\left(38^{\circ} 29^{\prime} \mathrm{N}, 54^{\circ} 19^{\prime} \mathrm{W}\right)$ had to be modified because of tropical storm Amy. Thus, we altered course at $1600 \mathrm{Z}$ on 2 July and proceeded southwest to drill the flank of Nashville Seamount (Figures 1 and 2). In order to check the seismic section before drilling, we steamed along course $248^{\circ}$, intersecting the Vema-2207 reference profile above the summit of Nashville Seamount on 5 July 1975 (Figure 3). At that point the ship turned southeast along course $113^{\circ}$, running parallel to the Vema track onto the Sohm Abyssal Plain. After we confirmed that the intended site location was suitable for drilling, the ship executed a Williamson turn at $1300 \mathrm{Z}$, returning along course $293^{\circ}$. Speed was reduced to 6 knots at $1323 Z$, and a beacon was dropped at 1358Z. PDR water depth at the beacon location was 5526 meters. The position of Site 382, determined from averaging satellitenavigation fixes 425 through 442 , is $34^{\circ} 25.04^{\prime} \mathrm{N}$, $56^{\circ} 32.25^{\prime} \mathrm{W}$.

Several distinct differences were noted between the Vema-2207 reference profile and the Challenger seismic section, even though the two ship tracks were close to one another (Figures 2, 3, and 4). It is probable that navigational inaccuracies in the (pre-satellite navigation) Vema track account for most of the discrepancy. The Vema record shows a relatively smooth southeast slope for Nashville Seamount, with an acoustically nonlaminated sediment interval lapping onto its lower flank (Figure 2). This acoustic unit extends laterally into a quasiconformable layer blanketing the adjacent basement topography beneath the acoustically laminated sediments of the Sohm Abyssal Plain. Acoustic basement beneath the abyssal plain merges uniformly with the slope of the seamount in the Vema record.

The southeast slope of Nashville Seamount is slightly more irregular in the Challenger profile and is separated from the deep-basin acoustic basement by a small basement peak (Figure 4). Some sediments shed from the seamount have ponded behind this ridge, but the reflectivity of their internal laminae in comparison with those of the abyssal plain suggests fewer and less welldeveloped interbeds of coarse sediment in this sequence. The nonlaminated sediments beneath the Sohm Abyssal 


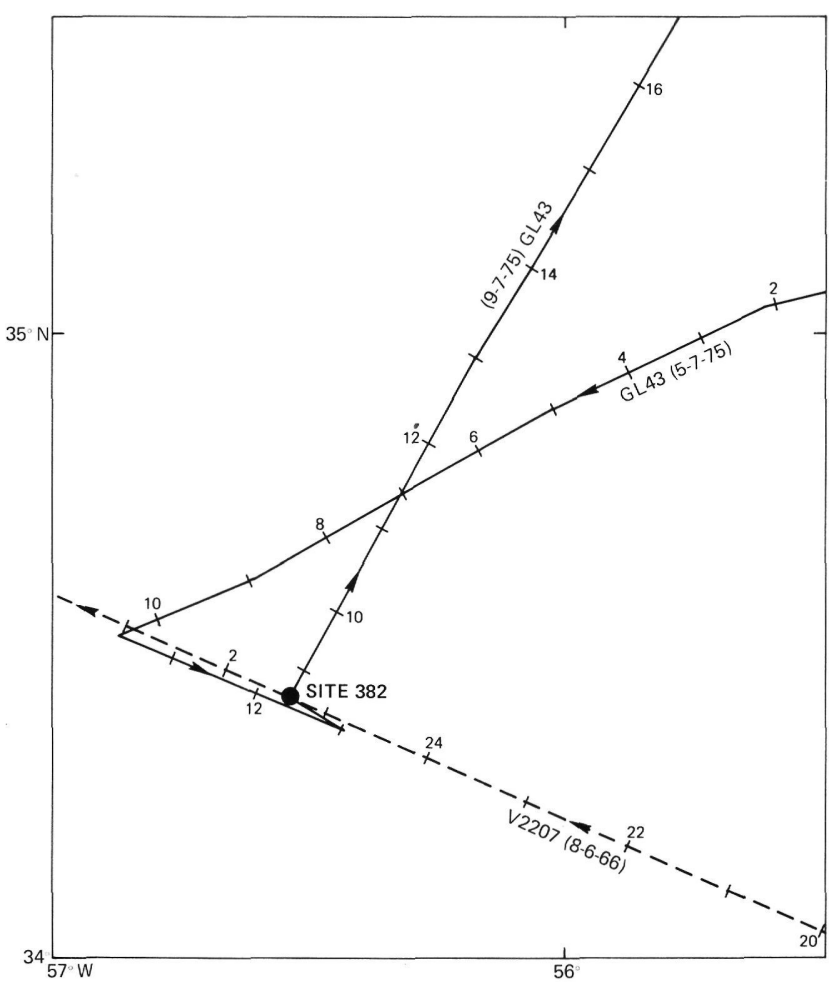

Figure 3. Location of Glomar Challenger track and Vema 2207 reference track near Site 382. Hour ticks are annotated (Challenger tracks in GMT).

Plain do not rise and separate the seamount flank from the Sohm turbidities as in the Vema profile, but they lap up slightly on the small ridge.

The site selected for drilling exhibits about $0.27 \mathrm{sec}$ of acoustically laminated sediment overlying $0.17 \mathrm{sec}$ of nonlaminated sediment, with acoustic basement near $0.44 \mathrm{sec}$ below the sea floor. A weak, irregular reflector, possibly representing original ocean crust, lies at about $0.57 \mathrm{sec}$. It was anticipated that drilling at this location would yield maximum information about the sedimentary record, in addition to being close enough to the seamount to recover volcanogenic detritus and basalt and to date the age of volcanism.

The bottom-hole assembly was magnafluxed and made up as we positioned over the beacon, and drill pipe was run in beginning about 1500 hours on 5 July. Bottom was reached at 0540 hours, 6 July, when the total length of pipe below the rig floor was 5537 meters. The drill-pipe water depth of 5527 meters was accepted as the Site $\mathbf{3 8 2}$ water depth.

The first 50 meters of sediment were washed, and Core 1 was recovered at 0742 hours. Because the driller felt for bottom without circulation, it is probable that the upper part of Core 1 also contains sediment from near the sea floor. The section was intermittently cored down to 269 meters (see Table 1, Figure 5, and coring rates in Figure 11). Continuous coring was begun at 269 meters to assure recovery of volcanogenic detritus at and above the level of acoustic basement. Core 19 was cut and left in the drill string while washing the next joint. Hard drilling was encountered in the washed interval (392.8-402.8 meters), and Core 19 contained basalt breccia when retrieved. Minor hard drilling at the level of Core 19 may represent thin breccia layers which plugged the bit at the Core 19 level and prevented recovery of sediments, but which were freed in the deeper, hard breccia. It therefore appears that most of the breccia actually recovered in Core 19 comes from the interval washed immediately below Core 19 .

With the primary objective of dating the cessation of volcanism achieved, we used the remaining time to spotcore the volcaniclastic section, in hope of reaching original oceanic crust and dating the initiation of seamount volcanism. Every third joint was cored below 421 meters, and difficulty was experienced retrieving several cores from the volcanogenic unit. In particular, Core 24 sheared the pin in the overshot and required pumping mud to clear the end of the core barrel before the core could be recovered. Very hard drilling ( $3 \mathrm{~m} / \mathrm{hr})$ was encountered at 516 meters (Figures 5 and 11). Because of the slow penetration and lack of time, drilling was terminated after 4 meters of penetration, and the drill string was pulled.

Core recovery decreases systematically over the first four cores $(100 \%$ down to $14 \%$ ) (Figure 5). It is probable that increasingly consolidated clays over this interval became ineffective in sealing unconsolidated silts and sands in the core barrel. Core recovery was uniformly high for the homogeneous clays recovered between depths of 210 and 355 meters. In the volcanogenic materials below, recovery was erratic. Higher pump pressure required to drill hard formations in some of these joints undoubtedly washed away less well-consolidated material and thereby reduced core recovery. In some instances (e.g., Core 19) the bit may have become plugged by resistant material such as the breccia recovered at two levels in the hole.

The ship was underway toward to Site 383 at 0530 on 9 July on a course paralleling the local strike of acoustic basement. Two sonobuoy recordings were attempted, but neither was successful.

\section{LITHOLOGY}

On the basis of 31.4 per cent recovery of the total depth drilled, the sedimentary section at Site 382 can be divided into three primary lithofacies hereafter referred to as units and interpreted as:

1) turbidites (0 to $232 \mathrm{~m}$ );

2) hemipelagic clay (232 to $352 \mathrm{~m})$;

3) volcanogenic sediment ( 352 to $520 \mathrm{~m}$ ).

The composition of these units, based on smear slides, is summarized in Foldout II at the back of this volume, and the ages and thickness of the units and sub-units are given in Table 2 . 


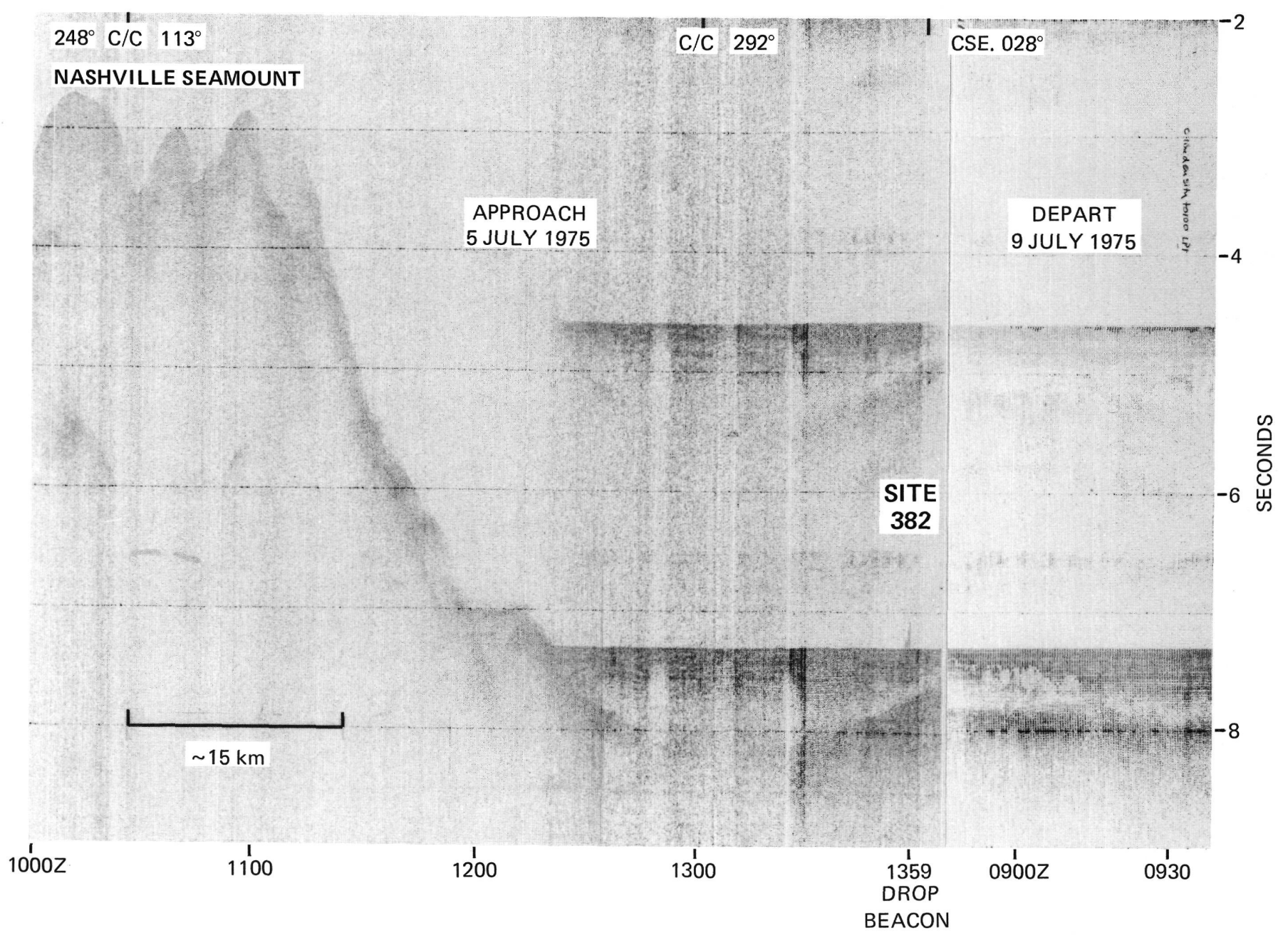

Figure 4. Challenger profile across and at Site 382. Note course changes returning ship to base of seamount, where Site 382 was drilled. Location in Figure 3.

\section{Unit 1 - Turbidites (0 to $232.3 \mathrm{~m})$}

Unit 1 was cored intermittently, and it consists of Quaternary and upper Pliocene beds of quartzose silty clay (about $75 \%$ of the unit) and feldspathic quartzose silt and sand (about $25 \%$ of the unit). Individual beds are dark gray, dark grayish brown, dark brown, brown, or reddish brown. They range in thickness from a few $\mathrm{mm}$ to 1.2 meters with most beds less than $50 \mathrm{~cm}$ thick. Silty clay is the dominant lithology (90-95\%) in the upper and lower portions of the unit (Cores 1, 4, and 5) with silt and sand more abundant (30-55\%) in the middle portion (Cores 2 and 3 ).

Most of the silty clay beds have sharp upper and lower contacts, but gradational contacts are common. Many of the silty clay beds have thin (up to a few $\mathrm{mm}$ thick) stringers of silt scattered throughout. The stringers are parallel to bedding planes (horizontal) and are generally darker (mostly dark grayish brown) than the silty clays. Eleven thicker beds of silt and sand $(6 \mathrm{~cm}$ to $1.2 \mathrm{~m}$; average $\approx 30 \mathrm{~cm}$ ) were cored in Unit 1 and they generally are darker shades of gray and brown. These beds are mostly silt but some contain abundant fine to medium sand, and one graded bed (Core 2, Sec.2,
55-105 cm) contains coarse sand grains (including pelecypod fragments) at the base. Virtually all the coarser beds have sharp lower contracts and about half of the upper contacts are sharp and half gradational. At least two of the beds are graded and several others may have been graded before coring disturbance disrupted them.

The general composition of Unit 1 based on smear slide descriptions and $\mathrm{X}$-ray data is:

\begin{tabular}{ll}
\hline A. Quartzose Silty Clay & B. \\
& $\begin{array}{l}\text { Feldspathic Quartzose } \\
\text { Silt and Sand }\end{array}$ \\
\hline Clay $=57 \%$ & Clay $=20 \%(10-40 \%$ range $)$ \\
Quartz $=23 \%$ & Quartz $=46 \%(25-60 \%)$ \\
Feldspar $=10 \%$ & Feldspar $=20 \%(10-25 \%)$ \\
Unspecified carbonate $=5 \%$ & Unspecified carbonate $=7 \%$ \\
Nannos $=3 \%$ & Nannos $=2 \%$ \\
Volcanic glass $=1 \%$ & Volcanic glass $=2 \%$ \\
Plant debris and heavy & Plant debris $=1 \%$ \\
minerals $=$ traces & Heavy minerals $=1 \%$ \\
& Glauconite $=1 \%$ \\
\hline
\end{tabular}


TABLE 1

Coring and Drilling Summary, Site 382

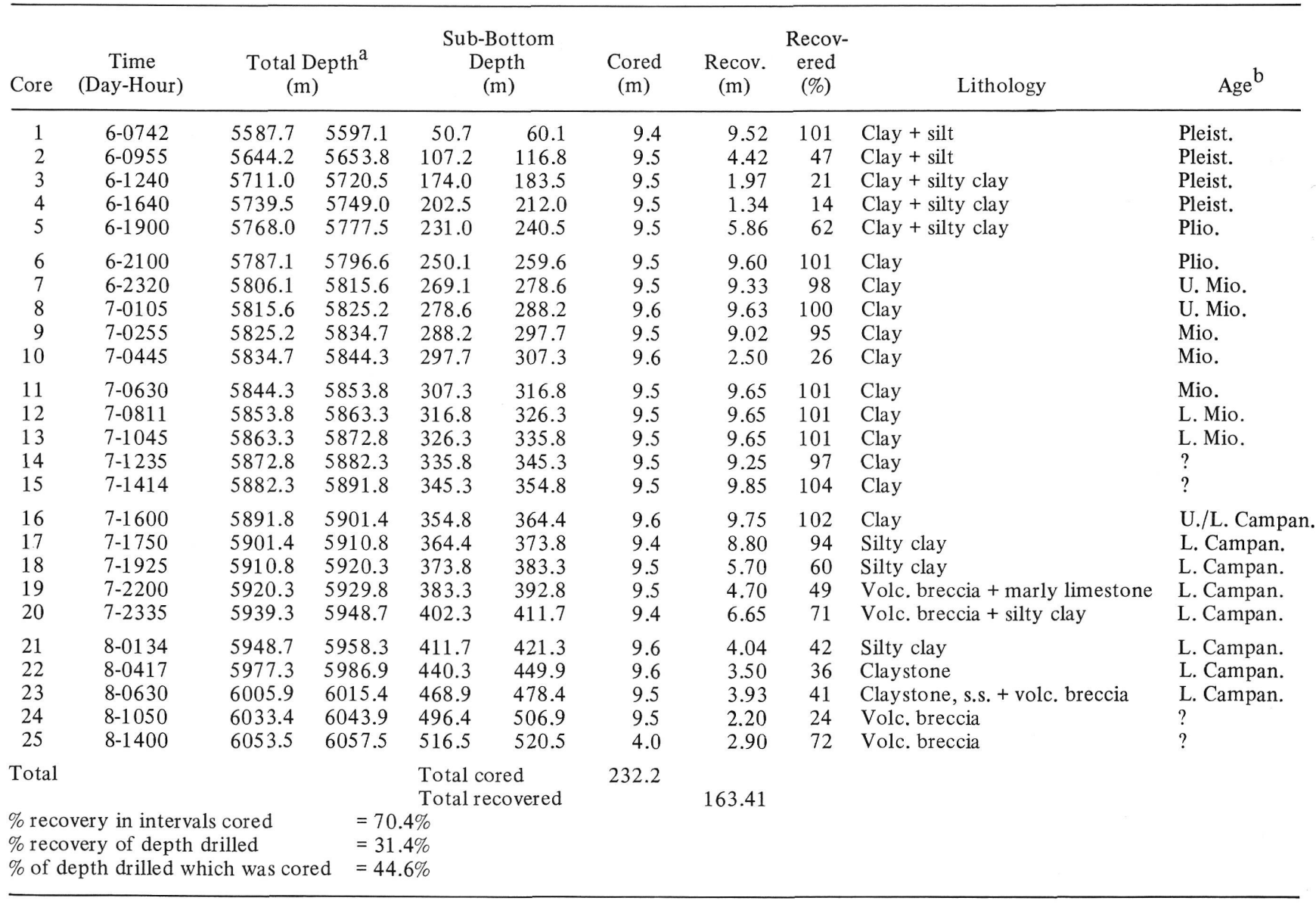

${ }^{\mathrm{a}}$ From rig floor, 10 meters above sea level.

${ }^{\mathrm{b}} \mathrm{U}=$ upper; $\mathrm{L}=1$ lower.

Clay and quartz are dominant in the silty clay, averaging about 80 per cent of the total, and clay, quartz, and feldspar comprise about 85 per cent of the silts and sands. X-ray diffraction analysis of seven samples from Unit 1 shows that the $<2 \mu \mathrm{m}$ carbonate-free fractions averages about 75 per cent mica/illite; 15 per cent chlorite, and 10 per cent kaolinite, with negligible montmorillonite (Koch and Rothe, this volume). A few beds are calcareous, but $\mathrm{CaCO}_{3}$ generally amounts to 10 per cent or less of the total. Five carbonate-bomb determinations on various beds indicate an average of 6 per cent $\mathrm{CaCO}_{3}$. However, there are enough nannofossils and foraminifers present to give good age control on the unit. A typical silty clay contained 0.4 per cent organic carbon.

Unit 1 is interpreted as a turbidite sequence for the following reasons: (1) the large percentage of terriginous quartz in the unit, (2) the presence of plant debris, especially in the coarser beds, (3) the high rate of accumulation (about $120 \mathrm{~m} / \mathrm{m} . \mathrm{y}$.), (4) the preponderance of reworked upper Cretaceous nannofossils (see Biostratigraphy), (5) the presence of a few megascopically graded beds. Because of the relative paucity of coarse debris and obviously graded beds and because of the physiographic location of the site, the unit is interpreted as a distal turbidite sequence. Several brown and reddish brown silty clay beds are strikingly similar to the "rose-gray lutite" carried south from the Laurentian Channel along the continental rise by the Western Boundary Undercurrent (Heezen et al., 1966). Thus, they may indicate sediment provenance for at least portions of Unit 1 in the Canadian Maritime Provinces with emplacement via the Laurentian Channel. The clay mineralogy also indicates sediment provenance in the mica-rich and mechanically weathered Maritime Provinces.

The presence of high latitude foraminifer species throughout most of Unit 1 (see Biostratigraphy) indicates that most of the turbidites were deposited during Pleistocene glacial maxima rather than during interglacials. Although the first core was taken 50.7 to 60.1 meters below the sea floor, the high average rate of accumulation and the acoustic character of the overlying sediments indicate that the entire interval down to 232 meters consists of turbidites. The contact with the underlying Unit 2 is marked by a sharp color change in Core $5-1,131 \mathrm{~cm}$. The contact corresponds to a disconformity between upper Pliocene turbidites and 
SITE 382

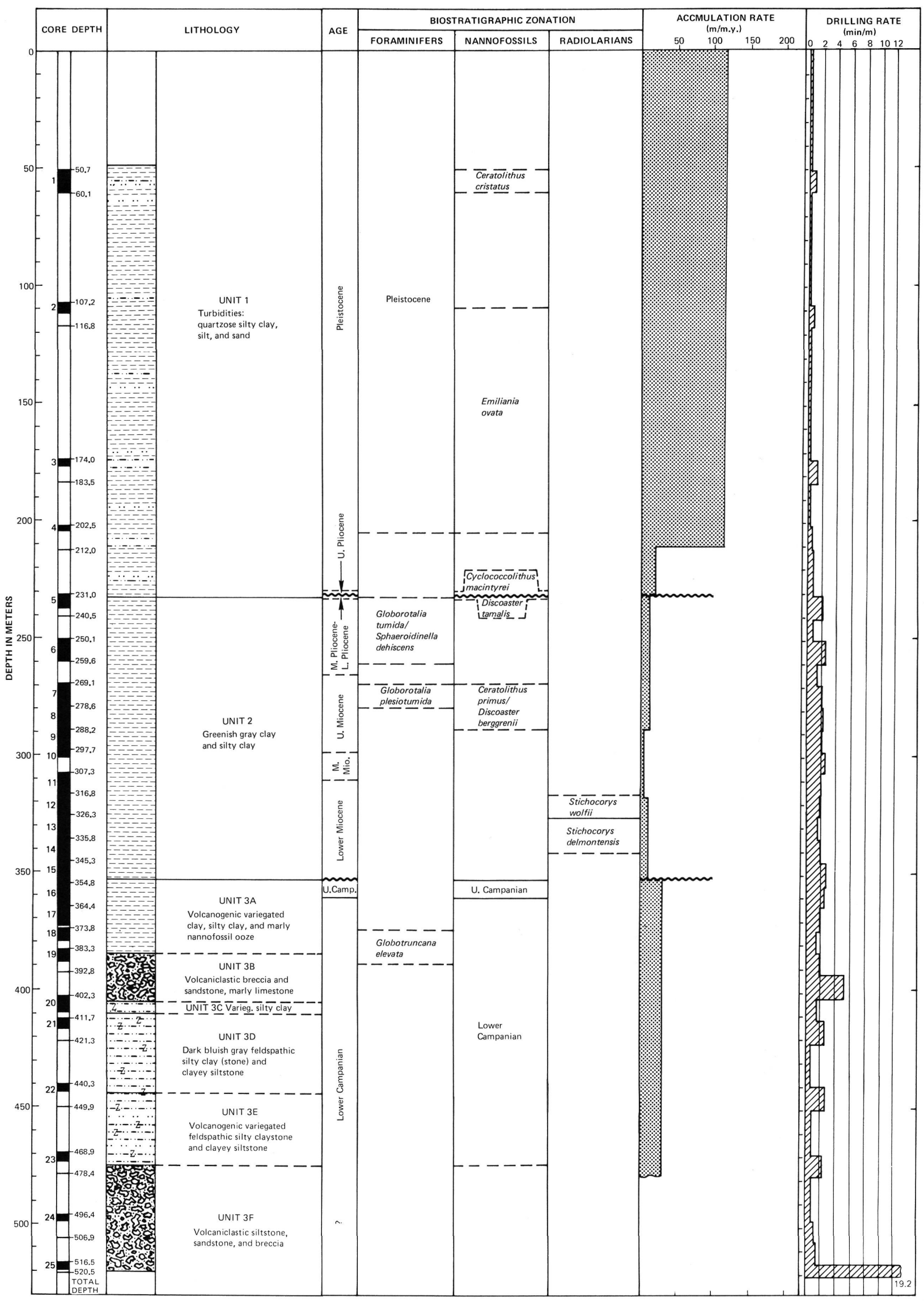

Figure 5. Graphic hole summary, Site 382. 
TABLE 2

Lithologic Units at Site 382

\begin{tabular}{|c|c|c|c|c|c|}
\hline Unit & Lithology & Age & $\begin{array}{l}\text { Thickness } \\
\text { (m) }\end{array}$ & $\begin{array}{l}\text { Sub-Bottom Depth } \\
\text { at Bottom of } \\
\text { Unit (m) }\end{array}$ & Cores \\
\hline 1 & $\begin{array}{l}\text { Quartzose silty clay, } \\
\text { silt, and sand }\end{array}$ & $\begin{array}{l}\text { Quaternary- } \\
\text { U. Pliocene }\end{array}$ & 232.3 & 232.31 & 1 to $5-1,131 \mathrm{~cm}$ \\
\hline 2 & $\begin{array}{l}\text { Greenish gray clay } \\
\text { and silty clay }\end{array}$ & $\begin{array}{l}\text { M. Pliocene } \\
\text { to L. Miocene }\end{array}$ & 119.8 & 352.12 & $\begin{array}{l}5-1,131 \mathrm{~cm} \text { to } \\
15-5,22 \mathrm{~cm}\end{array}$ \\
\hline $3 \mathrm{~A}$ & $\begin{array}{l}\text { Variegated clay, } \\
\text { silty clay and marly } \\
\text { nannofossil ooze }\end{array}$ & $\begin{array}{l}\text { U. Campanian to } \\
\text { L. Campanian }\end{array}$ & 33.1 & 385.18 & $\begin{array}{l}15-5,22 \mathrm{~cm} \text { to } \\
19-2,38 \mathrm{~cm}\end{array}$ \\
\hline $3 \mathrm{~B}$ & $\begin{array}{l}\text { Volcaniclastic } \\
\text { breccia and sand- } \\
\text { stone and marly } \\
\text { limestone }\end{array}$ & L. Campanian & 19.6 & 404.80 & $\begin{array}{l}19-2,38 \mathrm{~cm} \\
20-2,100 \mathrm{~cm}\end{array}$ \\
\hline $3 \mathrm{C}$ & Variegated silty clay & L. Campanian & 4.2 & 409.01 & $\begin{array}{l}20-2,100 \mathrm{~cm} \\
20-5,71 \mathrm{~cm}\end{array}$ \\
\hline $3 \mathrm{D}$ & $\begin{array}{l}\text { Feldspathic silty } \\
\text { clay (stone) and } \\
\text { clayey siltstone }\end{array}$ & L. Campanian & 35.5 & 444.53 & $\begin{array}{l}20-5,71 \mathrm{~cm} \\
22-3,123 \mathrm{~cm}\end{array}$ \\
\hline $3 \mathrm{E}$ & $\begin{array}{l}\text { Variegated feld- } \\
\text { spathic silty clay- } \\
\text { stone and clayey } \\
\text { siltstone }\end{array}$ & L. Campanian & 28.8 & 473.36 & $\begin{array}{l}22-3,123 \mathrm{~cm} \text { to } \\
23-3,56 \mathrm{~cm}\end{array}$ \\
\hline $3 F$ & $\begin{array}{l}\text { Volcaniclastic silt- } \\
\text { stone, sandstone, } \\
\text { and breccia }\end{array}$ & $?$ & 47.1 & $520.50+$ & $\begin{array}{l}23-3,56 \mathrm{~cm} \\
\text { through } 25\end{array}$ \\
\hline
\end{tabular}

mid-Pliocene hemipelagic clay (see Biostratigraphy), and it represents a 0.5 to 1.0 million year hiatus.

\section{Unit 2 - Hemipelagic Clay (232.3 m to $352.1 \mathrm{~m}$ )}

Unit 2 was cored continuously and is composed of relatively homogeneous Miocene to Pliocene dark greenish gray clay and silty clay. The clays are moderately mottled and contain darker layers, streaks, and burrow fillings that are enriched in pyrite and hydrotroilite. Light gray silty specks enriched in quartz and feldspar are sparsely scattered throughout the unit. Cylindrical, indurated pyrite burrow fillings up to $1 \mathrm{~cm}$ in diameter and $2 \mathrm{~cm}$ long occur in the middle of the unit (Cores 7, 8, 9, and 11) and indurated burrow fillings that are carbonate rich occur in Cores 6 and 9. The upper half of the unit (Cores 5, 7, 8, and 9) contains a total of 7 thin $(3 \mathrm{~mm}$ to $3 \mathrm{~cm}$ ) interbeds of light brown and gray calcareous clays and oozes. Some foraminifers and nannofossils can be distinguished, but most of the carbonate is micritic. Core 11 contains rare brownish calcareous burrow fillings with some nannofossils but mostly with unspecified carbonate. Altered vesicular basalt fragments, similar to those in the breccias of the underlying unit, occur in Cores 9 and 10 and are up to 1 $\mathrm{cm}$ by $5 \mathrm{~cm}$ in size.

The average composition of Unit 2 determined from smear slides and $\mathrm{X}$-ray analyses is:

Clay $=75 \%$

Quartz $=17 \%$

Feldspar $=5 \%$

Volcanic glass $=2 \%$
Unspecified carbonate, nannofossils, radiolarians, plant debris, heavy minerals, pyrite, and zeolites $=$ trace amounts

There is very little compositional variation in Unit 2 . The upper third may be slightly coarser grained and may contain enough additional quartz to merit designation as "quartzose silty clay." The middle third may be slightly finer grained (clay), and the lower third may be intermediate in grain size and quartz content (quartzose clay). However, the overall variation in clay and quartz percentages, and in minor components, is insignificant in this 120-meter-thick unit. Plant debris may be slightly more common in the upper portion of the unit and zeolites and radiolarians slightly more common in the lower portion. X-ray diffraction patterns of 16 samples from Unit 2 show that the $<2 \mu \mathrm{m}$ carbonate-free fraction averages about 70 per cent montmorillonite, 20 per cent mica/illite, 5 per cent kaolinite, and 5 per cent chlorite. Thus, there is a clear change in clay mineralogy from the overlying Unit 1.

Unit 2 is interpreted as a hemipelagic clay (silty clay) which accumulated below the carbonate compensation depth (CCD). The presence of quartz and plant debris suggests some terrigenous input, and the lack of authigenic phases suggests a hemipelagic rather than a pelagic origin. Greenish-gray hemipelagic clay of late Tertiary age was cored at six sites in the western North Atlantic during DSDP Leg 11 (Hollister, Ewing et al., 1972), and it closely resembles Unit 2.

There is no indication of turbidites within the unit, so most of the terrigenous debris was probably transported 
to the site by bottom currents (see Lancelot et al., 1972). Burrow mottles indicate that the bottom water was oxygenated, but pyrite in the burrow fillings suggests that reducing conditions prevailed below the sediment surface. The altered vesicular basalt fragments in Cores 9 and 10 probably slumped from the steep flanks of Nashville Seamount. The lack of associated volcanogenic debris indicates that these basalt fragments do not represent renewed volcanic activity on Nashville Seamount.

Although the predominantly greenish color of Unit 2 becomes somewhat browner in the lowermost few meters, the contact between Unit 2 and underlying Unit 3 is marked by a sharp color change in Core 15 , Section $5,22 \mathrm{~cm}$. The contact corresponds to a disconformity between lower Miocene hemipelagic clay and upper Campanian variegated clay (see Biostratigraphy) and it represents a hiatus of about 50 million years.

\section{Unit 3 - Volcanogenic Sediment (352.1 to 520.5 m)}

The bottom 168 meters at the site were cored intermittently and the various lithofacies encountered are considered as a single unit because of their volcanogenic origin. Texturally, silty clay and clayey silt dominate in the unit, with breccia being next most common. Based on differences in color, texture, and composition, Unit 3 is divided into six sub-units (Table 2).

\section{Sub-Unit 3A - Variegated Clay, Silty Clay, and Marly Nannofossil Ooze}

The beds comprising Sub-unit $3 \mathrm{~A}$ are variegated, mostly shades of brown, grayish brown, and reddish brown. Most beds are laminated, with individual laminae distinguished mostly by color differences and less often by textural and/or compositional differences (Figure 6). Many adjacent laminae have identical compositions as determined from smear slides. Rare cross laminations occur throughout Sub-unit 3A. Color contacts vary from diffuse to sharp and mottling ranges from nil to intense. The carbonate content of the subunit is bimodally distributed. Ten carbonate-bomb determinations show that the marly nannofossil oozes average 45 per cent carbonate and the less calcareous clays and silty clays average 8 per cent. Smear-slide estimates are 40 and 10 per cent, respectively. The oozes are generally more mottled and less laminated than the noncalcareous beds and generally more brownish than reddish. Inoceramus plates occur in Cores 16 and 18 , a Zoophycos burrow in Core 18, and calcareous Cylindrichnus burrow fillings in Core 19. Rare black dendrites are scattered throughout the sub-unit and occur along some bedding planes.

The clays and silty clays of Sub-unit $3 \mathrm{~A}$ are locally feldspathic and calcareous. Average composition determined from smear-slide descriptions and X-ray data is:

Clay $=50-85 \%$, avg. $=70 \%$

Feldspar $=2-28 \%$, avg. $=9 \%$
Unspecified carbonate $=0-28 \%$, avg. $=6 \%$

Nannofossils $=0-15 \%$, avg. $=4 \%$

Zeolites $=4 \%$

Quartz $=3 \%$

Volcanic glass $=1 \%$

Palagonite $=1 \%$

Heavy minerals $=1 \%$

The average composition of the oozes of Sub-unit 3A determined from smear-slide descriptions, carbonatebomb results, and $\mathrm{X}$-ray data is:

$$
\begin{aligned}
& \text { Clay }=45 \% \\
& \text { Nannofossils }=21 \% \\
& \text { Unspecified carbonate }=19 \% \\
& \text { Feldspar }=8 \% \\
& \text { Volcanic glass }=2 \% \\
& \text { Zeolites }=2 \% \\
& \text { Quartz }=1 \% \\
& \text { Heavy minerals }=1 \% \\
& \text { Palagonite }=1 \%
\end{aligned}
$$

Detrital feldspar, unspecified carbonate, and zeolite grains up to $3 \mathrm{~mm}$ in diameter are scattered throughout some clay and silty clay intervals and in the basal portions of others. In the oozes of the upper half of the subunit, nannofossils are generally more abundant than unspecified carbonate and in the lower half the trend is reversed. Most of the unspecified carbonate in the oozes probably is recrystallized nannofossils.

Coarser interbeds of siltstone and sandstone form a minor (less than 10\%) but persistent component of Subunit 3A. Beds range in thickness from $1 \mathrm{~mm}$ to $6 \mathrm{~cm}$, but most are less than $3 \mathrm{~cm}$ thick. Grain size ranges from silt to very coarse sand. These indurated interbeds are generally in sharp contact with the nonindurated major lithologies and they usually have darker shades of brown than other beds. Some of the interbeds are crudely graded, and some have erosional basal contacts. A 6-cm medium to coarse sandstone bed in Core 17 contains foraminifers and calcareous shell fragments.

The coarser interbeds of Sub-unit $3 \mathrm{~A}$ are mostly feldspathic silts that are locally zeolitic or locally calcareous. Average composition of these indurated interbeds as determined from smear slides and X-ray data is:

$$
\begin{aligned}
& \text { Clay }=20-50 \%, \text { avg. }=36 \% \\
& \text { Feldspar }=10-32 \%, \text { avg. }=21 \% \\
& \text { Zeolites }=1-22 \%, \text { avg. }=14 \% \\
& \text { Unspecified carbonate }=3-38 \%, \text { avg. }=12 \% \\
& \text { Volcanic glass }=5 \% \\
& \text { Palagonite }=3 \% \\
& \text { Nannofossils }=3 \% \\
& \text { Heavy minerals }=2 \% \\
& \text { Opaques }=2 \% \\
& \text { Quartz }=2 \%
\end{aligned}
$$

Compared with the major lithologies, the coarser interbeds are poorer in clay and richer in feldspar, zeolites, volcanic glass, palagonite, heavy minerals, and opaques. X-ray diffraction patterns indicate that some of the feldspar is orthoclase and some is hightemperature sanidine (Koche and Rothe, this volume). 


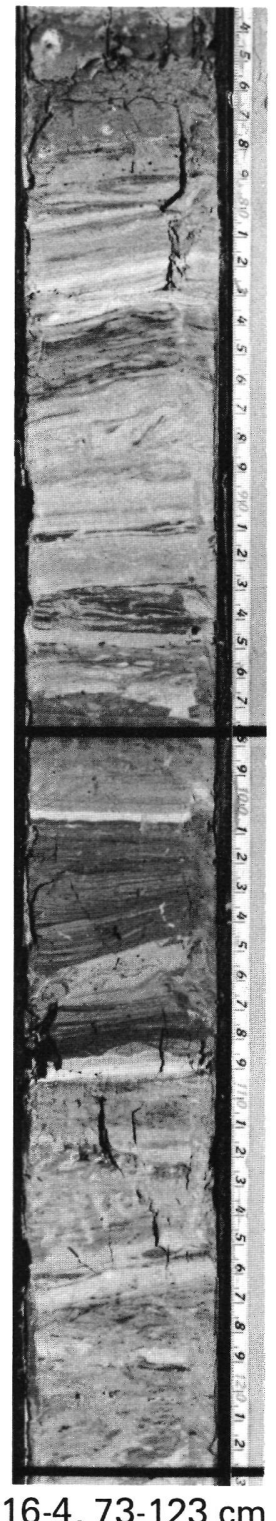

$16-4,73-123 \mathrm{~cm}$

a

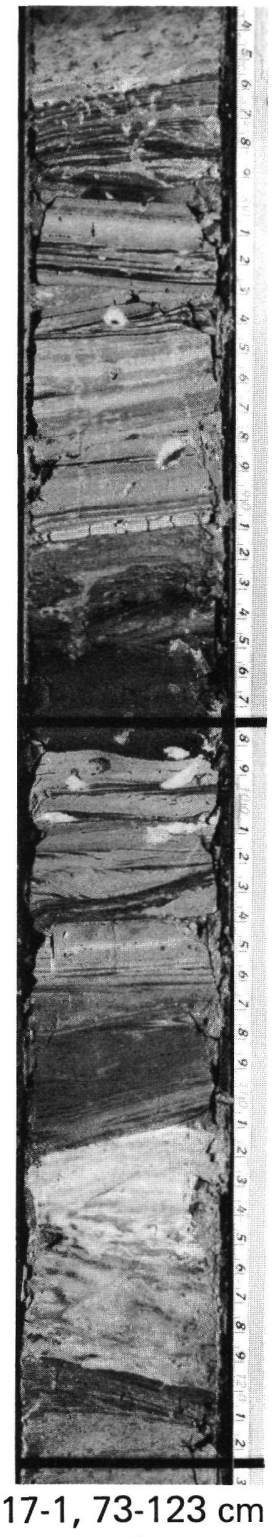

b
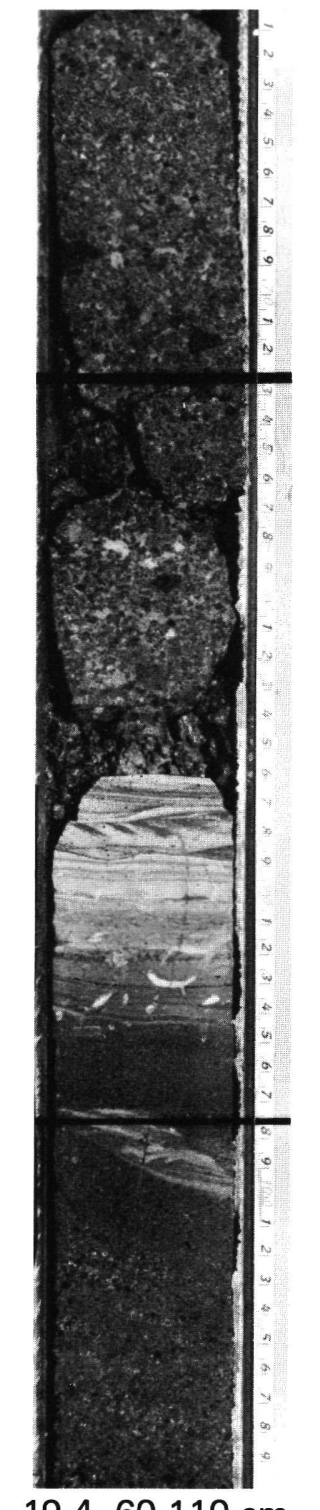

$19-4,60-110 \mathrm{~cm}$

c

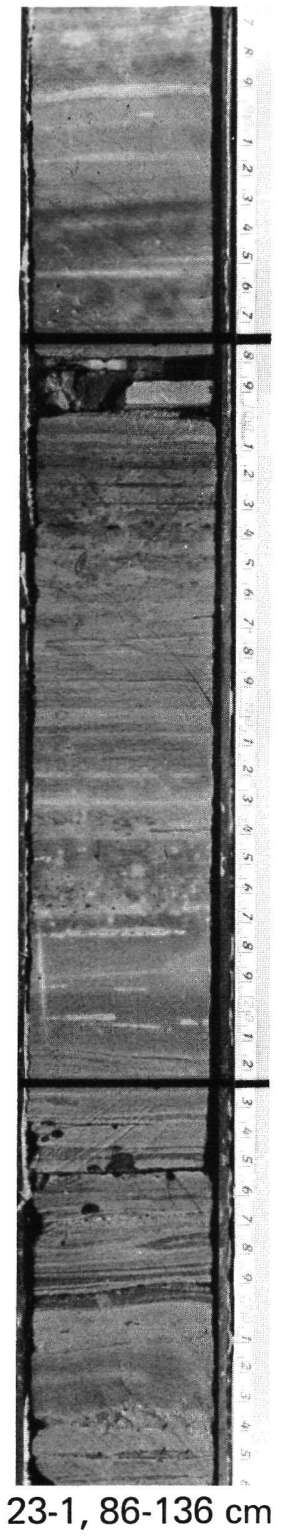

d

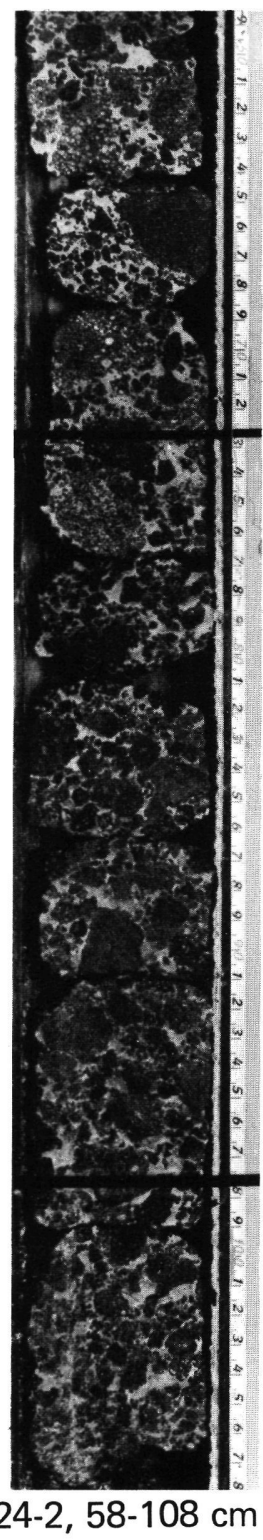

e

Figure 6. Examples of Unit 3 lithofacies. (a) Sub-unit $3 A$ variegated, laminated clay. (b) Sub-unit $3 A$ variegated, laminated clay and marly ooze. (c) Sub-unit $3 B$ volcaniclastic breccia and sandstone with interbedded marly limestone. (d) Sub-unit $3 E$ variegated silty claystone with silt/sand interbeds. (e) Sub-unit $3 F$ volcaniclastic breccia.

Authigenic K-feldspar and high temperature sanidine have been found in DSDP volcanogenic sediments previously (Berger and von Rad, 1972, p. 934, fig. 6). X-ray diffraction indicates the zeolites in $3 \mathrm{~A}$ are clinoptilolite and phillipsite (see Houghton et al., this volume).

$\mathrm{X}$-ray analysis of 17 samples from Sub-unit $3 \mathrm{~A}$ shows that the $<2 \mu \mathrm{m}$ carbonate-free fraction is of variable composition throughout the sub-unit. The upper portion (Sections 15-5 through 16-1) averages 66 per cent montmorillonite, 23 per cent mica/illite, 7 per cent kaolinite, and 4 per cent chlorite, but the middle (Sections 16-3 through 17-6) is virtually all montmorillonite, and the lower portion is highly variable. Section 18-1 has chlorite and kaolinite in sub-equal amounts; Section 
18-3 is mostly montmorillonite and mica/illite; and Section 18-4 is mostly mica/illite with some kaolinite and chlorite.

The contact with underlying Sub-unit 3B is sharp and occurs in Core 19, Section 2, $38 \mathrm{~cm}$, between the nonindurated calcareous silty clay of $3 \mathrm{~A}$ and indurated marly limestone of 3B.

\section{Sub-Unit 3B - Volcaniclastic Breccia and Sandstone Interbedded With Marly Limestone}

Seven beds of volcaniclastic breccia and six beds of volcaniclastic sandstone are interbedded with 14 beds of marly limestone in Sub-unit 3B (Figure 6). Breccia is the dominant volcaniclastic component of most of the 20-meter sub-unit, and sandstone occurs mostly in the lower $80 \mathrm{~cm}$. The breccia beds range in thickness from 5 to $97 \mathrm{~cm}$ and average about $50 \mathrm{~cm}$. Sorting in the breccias is poor. Most clasts are $2-5 \mathrm{~mm}$ in diameter and the maximum clast size in most beds is less than $1 \mathrm{~cm}$. The two largest clasts occur in the core catcher of Core 19 and are $2 \mathrm{~cm}$ by $4 \mathrm{~cm}$ and $3 \mathrm{~cm}$ by $3 \mathrm{~cm}$. The breccias are mostly composed of angular and sub-angular (some sub-rounded) altered vesicular-basalt clasts. The degree of angularity is partly a function of fragmentation across vesicle boundaries. Breccia clasts look spongy and are dominated by irregular, partly intersecting vesicles separated by basaltic septa ranging in color from yellow or red through brown or black. Vesicularity of the clasts ranges from 0 to 30 per cent, but it is commonly about 20 per cent, suggesting eruption at a water depth less than 1000 meters (Moore, 1965). Vesicles range from $0.2 \mathrm{~mm}$ to $1.5 \mathrm{~mm}$ in diameter, averaging $0.7 \mathrm{~mm}$.

Most basaltic clasts are extensively altered. Oxidation accounts for the dominant reddish brown color of the breccias. However, the extent of alteration is highly variable among clasts. All glass is devitrified, but some clasts still retain original groundmass texture, displaying fine intergrowths of plagioclase and pyroxene. The lessaltered clasts are usually shades of dark gray. In most of the reddish brown clasts, alteration to smectites is complete and even the phenocrysts show signs of degeneration. In the most completely altered specimens, subvariolitic aggregates of radial intergrowths of altered feldspar and quartz (produced by divitrification of glass) and secondary magnetite are common.

The breccias of Sub-unit 3B are mostly cemented by radiating light gray zeolite, with later minor calcite filling the remaining voids. Calcite cement is more abundant immediately adjacent to the marly limestone interbeds (Figure 7).

Basal contacts of the breccias with the interbeds are sharp. About half of the upper contacts are sharp and half gradational. Black dendrites occur along some of the sharp contacts. Portions of several breccia beds are cross-bedded with dips up to $20^{\circ}$ but more commonly $5-10^{\circ}$. Two beds are crudely graded and one appears to be reversely graded.

Volcaniclastic sandstone beds in Sub-unit 3B are essentially finer grained equivalents of the breccia.

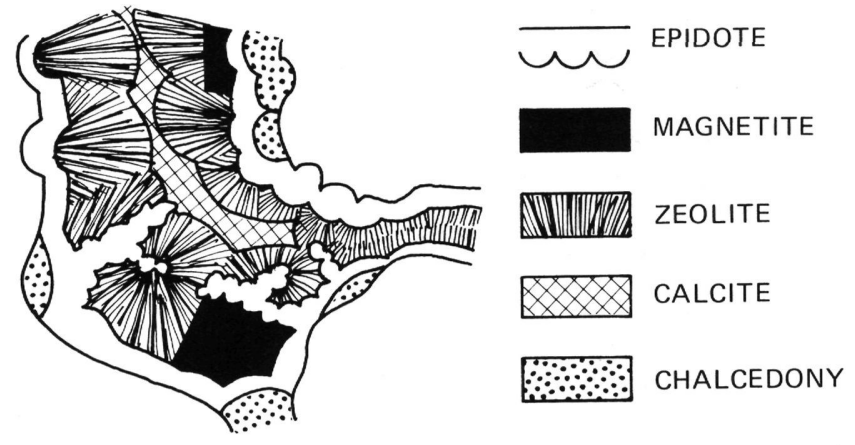

Figure 7. Idealized depiction of cementing agents between basaltic clasts in Unit 3 breccias.

Sandstone beds range in thickness from 1 to $8 \mathrm{~cm}$ and in grain size from very fine to coarse sand. Beds up to medium sand size contain single crystals of pyroxene, amphibole, and zeolite whereas coarser beds also contain lithic fragments of altered vesicular basalt. Sandstone beds are mostly shades of reddish brown and are in sharp contact with the calcareous interbeds.

The calcareous interbeds in Sub-unit 3B tend to be shades of grayish brown and light brown, and they consist of clay and unspecified carbonate in varying proportions. Mottling ranges from slight to intense with most beds moderately mottled. The calcareous beds are laminated and most are cross laminated (Figure 6). Bed thickness ranges from about 2 to $10 \mathrm{~cm}$. Black dendrites occur throughout and are concentrated in some bedding planes and contacts. Carbonate-bomb determinations show that the interbeds between the breccias are mostly marly limestones $\left(40-50 \% \mathrm{CaCO}_{3}\right)$ and interbeds between the sandstones are on the borderline between marly limestones and calcareous claystones (about $30 \% \mathrm{CaCO}_{3}$ ). An Inoceramus plate occurs in an interbed between breccias in Core 19.

The contact between marly limestone of Sub-unit 3B and underlying nonindurated variegated silty clay of Sub-unit $3 \mathrm{C}$ is gradational over about $25 \mathrm{~cm}$ and is placed at Core 20, Section 2, $100 \mathrm{~cm}$.

\section{Sub-Unit 3C - Variegated Silty Clay}

The beds comprising the 4 meters of Sub-unit $3 \mathrm{C}$ are variegated, mostly in shades of reddish brown and brown. Many beds are diffusely laminated with color contacts usually gradational. Rare cross laminations occur throughout the sub-unit. Slight to moderate, diffuse mottling occurs in some intervals. Rare black dendrites occur along some bedding planes and locally are aligned along vertical fractures.

The silty clays of Sub-unit $3 \mathrm{C}$ are locally feldspathic and/or locally zeolitic; average composition determined from smear-slide descriptions and X-ray data is:

$$
\begin{aligned}
& \text { Clay }=69 \% \\
& \text { Feldspar }=12 \% \\
& \text { Zeolites }=10 \% \\
& \text { Volcanic glass }=2 \% \\
& \text { Nannofossils }=2 \%
\end{aligned}
$$




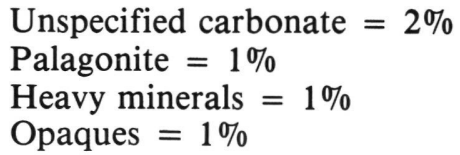

A comparison of the composition of these variegated beds with those of Sub-unit $3 \mathrm{~A}$ shows that $3 \mathrm{C}$ contains more zeolites and much less carbonate. Numerous stringers and thin ( $<1 \mathrm{~cm}$ thick) interbeds of coarser texture occur throughout $3 \mathrm{C}$, and they are similar to those in 3A. Most are shades of dark grayish brown and enriched in silt and fine sand sized feldspar and zeolite grains.

$\mathrm{X}$-ray analysis of three samples from Subunit 3C shows that the $<2 \mu \mathrm{m}$ carbonate-free fraction averages 75 per cent montmorillonite, 17 per cent chlorite, and 8 per cent kaolinite; the bulk samples indicate that the zeolites are phillipsite, analcite, and clinoptilolite.

The contact between the variegated silty clay of Subunit $3 \mathrm{C}$ and dark bluish gray silty clay of underlying Subunit 3D is sharp and occurs at Core 20, Sec. 5, $71 \mathrm{~cm}$.

\section{Sub-Unit 3D - Feldspathic Silty Clay(stone) and Feldspathic Clayey Siltstone}

The beds comprising the 36 meters of Sub-unit 3D are dark bluish gray silty clay(stone) and clayey siltstone. The sub-unit probably extends from about 409 meters to 445 meters, but only the upper $(409-421 \mathrm{~m})$ and lower (440-445 m) portions were cored. The beds in the upper portion are firm but slightly plastic, whereas the beds in the lower portion are indurated. Both portions are diffusely mottled with dark reddish brown, and both contain some intervals that are diffusely laminated and thinly laminated with extremely subtle, gradational color contacts. Cross laminations are very rare.

The average composition for Sub-unit 3D determined from smear-slide descriptions and $\mathrm{X}$-ray data is:

$$
\begin{aligned}
& \text { Clay }=40-85 \%, \text { avg. }=60 \% \\
& \text { Feldspar }=5-35 \%, \text { avg. }=20 \% \\
& \text { Zeolites }=2-20 \%, \text { avg. }=10 \% \\
& \text { Volcanic glass }=4 \% \\
& \text { Heavy minerals }=2 \% \\
& \text { Palagonite, quartz, nannofossils, and } \\
& \text { unspecified carbonate }=1 \% \text { each }
\end{aligned}
$$

The coarser grained portions of Sub-unit 3D are enriched in feldspar and zeolites and contain slightly more heavy minerals. The entire sub-unit is nearly carbonate free. X-ray analysis of four samples shows that the $<2 \mu \mathrm{m}$ carbonate-free fraction is virtually all montmorillonite; analysis of five bulk samples shows that the zeolites are mainly clinoptilolite and analcite.

More than 100 stringers and thin interbeds (from 1 $\mathrm{mm}$ to $5 \mathrm{~cm}$ in thickness, averaging less than $1 \mathrm{~cm}$ ) of dark bluish gray silt to medium sand occur throughout Sub-unit 3D. These beds are enriched in feldspar and zeolites and most are in gradational contact with the major lithology. Two 1-cm-thick, light yellowish brown and grayish brown sandy interbeds occur in the upper portion of the sub-unit, and one 5-mm-thick silty graded bed was noted in the lower portion.
Sub-unit 3D is in sharp basal contact with underlying variegated Sub-unit $3 \mathrm{E}$ at $22-3,123 \mathrm{~cm}(444.53 \mathrm{~m}$ subbottom). However, about $50 \mathrm{~cm}$ of bluish gray silty claystone occurs at the top of Core 23 (about 469 m subbottom) within $3 \mathrm{E}$ and is virtually identical to the lithology of 3D.

\section{Sub-Unit 3E - Variegated Feldspathic Silty Claystone and Feldspathic Clayey Siltstone}

The beds comprising Sub-unit $3 \mathrm{E}$ are brownish and reddish brown silty claystone and clayey siltstone. This sub-unit presumably extends through an interval of about 29 meters from about 445 meters to 473 meters, but only the upper 0.5 meters at 445 meters and the lower 2.3 meters at 471-473 meters were cored. The upper portion is more variegated than the lower. Both contain intervals that are diffusely laminated and occasionally cross laminated. The upper portion is moderately mottled and locally calcareous.

Dark brown and dark grayish brown stringers and thin $(<1 \mathrm{~cm}$ thick) coarser interbeds of siltstone and fine sandstone occur throughout the sub-unit (Figure 6). Altered vesicular basalt fragments up to $4 \mathrm{~mm}$ in diameter occur in one claystone bed in the lower portion, and one $1-\mathrm{cm}$-thick, coarse to medium, graded sandstone bed occurs in the lower portion.

The average composition of Sub-unit 3E determined primarily from smear slides is:

$$
\begin{aligned}
& \text { Clay }=40-85 \%, \text { avg. }=63 \% \\
& \text { Feldspar }=2-25 \% \text {, avg. }=16 \% \\
& \text { Zeolites }=2-10 \% \text {, avg. }=8 \% \\
& \text { Volcanic glass }=4 \% \\
& \text { Unspecified carbonate }=0-20 \%, \text { avg. }=4 \% \\
& \text { Heavy minerals }=3 \% \\
& \text { Palagonite }=1 \% \\
& \text { Nannofossils }=1 \%
\end{aligned}
$$

$\mathrm{X}$-ray diffraction analyses of two samples from the subunit show that the $<2 \mu \mathrm{m}$ carbonate-free fraction is virtually all montmorillonite.

A comparison of the average composition of Subunit $3 \mathrm{E}$ with those of the megascopically similar variegated Sub-units $3 \mathrm{~A}$ and $3 \mathrm{C}$ shows that $3 \mathrm{E}$ has a composition very similar to that of $3 \mathrm{C}$, containing more zeolites and much less carbonate than $3 \mathrm{~A}$. However, the clay in $3 \mathrm{E}$ is all montmorillonite whereas $3 \mathrm{~A}$ and $3 \mathrm{C}$ contain significant kaolinite and chlorite in addition to montmorillonite. Sub-unit $3 \mathrm{~A}$ also has portions rich in mica/illite.

A comparison of the average composition of Subunit $3 \mathrm{E}$ with that of the dark bluish gray beds of overlying Sub-unit 3D shows that the two sub-units are compositionally similar although they are megascopically quite different. The compositional similarity even extends to the detailed clay mineralogy with both subunits containing only montmorillonite.

The lower portion of Sub-unit 3E grades into the upper portion of underlying Sub-unit 3F; the two sub-units are interbedded over an interval of about 3 meters. The contact is placed at Core 23 , Sec. $3,56 \mathrm{~cm}(473.36 \mathrm{~m}$ subbottom) with the 2.3 meters above the contact contain- 
ing about 75 per cent Sub-unit 3E lithology and the 0.7 $\mathrm{m}$ below the contact about 90 per cent Sub-unit $3 \mathrm{~F}$ lithology.

\section{Sub-Unit 3F - Volcaniclastic Siltstone, Sandstone, and Breccia}

The upper $74 \mathrm{~cm}$ (in Core 23) of this $>47$-meterthick sub-unit is volcaniclastic siltstone and sandstone interbedded with minor Sub-unit 3E lithofacies. The siltstones and sandstones are similar to the sandstones of Sub-unit 3B and are finer grained equivalents of the underlying breccia. Grain size ranges from silt to fine sand except in a 12 -cm crudely graded, poorly sorted interval in which the basal portion is coarse sand size. Most beds are shades of grayish brown and some are moderately burrow-mottled with burrow fillings of reddish brown claystone. Most of the siltstone and sandstone beds contain single crystals of pyroxene, amphibole, and zeolite. Coarse sandstones contain lithic fragments of altered vesicular basalt. Many of the contacts with Sub-unit 3E interbeds of siltstone and claystone are sharp and appear to be erosional.

Volcaniclastic breccia is the dominant component of Sub-unit 3F (Figure 6). It has a gradational upper contact with volcaniclastic sandstone at Core 23, Section 3, $130 \mathrm{~cm}$, and its lower contact was not cored. Breccia comprises all of Cores 24 and 25 and interbeds either do not occur or were not recovered. In many respects, the breccia in $3 \mathrm{~F}$ is similar to that in $3 \mathrm{~B}$. Both are poorly sorted and both are composed of angular and subangular (some sub-rounded), mostly reddish brown vesicular basalt clasts in varying states of alteration. The comments made about 3B regarding angularity, vesicularity, and alteration also apply to the $3 \mathrm{~F}$ breccias. A few clasts in $3 \mathrm{~F}$ display zones of saussuritization yielding epidote vesicle fillings which hint at a component of hydrothermal alteration. In general, however, alteration is greater in the upper unit (3B). The freshest clast occurs at Core 25, Section 2, 5-8 $\mathrm{cm}$ and is a moderately altered, medium dark gray, hypocrystalline, porphyritic basalt with doleritic groundmass. It has 20 per cent vesicles displaying amygdaloidal infillings from center to rim of abundant calcite and radiating zeolite, scarce magnetite, and rare epidote.

The presence and distribution of phenocrysts of pyroxene, amphibole, plagioclase, and olivine define four alkali basalt types and one possible tholeiite in the volcanic clasts of Sub-units 3B and 3F. The extent of clast alteration varies widely, but clinopyroxene and hornblende laths are generally relatively fresh. Loose hornblende crystals up to $1 \mathrm{~cm}$ long are preserved in the sediment.

In general, calcite cement is more important in the breccias of Sub-unit 3F than in those of Sub-unit 3B. Zeolites are significant in Sub-unit 3F only near the upper contact or as vesicle fillings. Zeolites become very minor below Core 24, Section 2, where epidote commonly appears. Minor chalcedony is also present in places. Cement generally is more abundant relative to the clasts in the breccias of $3 \mathrm{~F}$ than in those of $3 \mathrm{~B}$.
Clasts, however, comprise a greater volume in the breccias in all intervals except for several thin (up to $6 \mathrm{~cm}$ thick) intervals in the Core 25 core catcher. Figure 7 is an idealized representation of the relationships among the various cementing agents in the breccias.

Generally horizontal bedding in the breccia is distinguished by intervals of different average clast size. Beds dipping at about $10^{\circ}$ occur in the Core 23 core catcher. The maximum clast size and the average clast size are both larger in $3 \mathrm{~F}$ breccia $(1 \mathrm{~cm}$ average and 3.5 $\mathrm{cm}$ by $5.5 \mathrm{~cm}$ maximum) than in that of 3B (2-5 mm average and 3 by $3 \mathrm{~cm}$ maximum.

Less altered clasts are generally dark gray, are randomly mixed with more altered clasts throughout the sub-unit, and are relatively more abundant in the lowest meter cored (Core 25). The five largest clasts in $3 \mathrm{~F} \mathrm{(} 3$ by $4 \mathrm{~cm}, 3$ by $5 \mathrm{~cm}, 2.8$ by $5.5 \mathrm{~cm}, 3$ by $6 \mathrm{~cm}$, and 3.5 by 5.5 $\mathrm{cm})$ are all relatively fresh.

\section{Discussion}

Unit 3 is interpreted as being almost entirely volcanogenic with only minor amounts of biogenic and terrigenous material. The overall accumulation rate for the unit is about $30 \mathrm{~m} / \mathrm{m}$.y. If the volcaniclastic breccias were emplaced during a very short time interval, however, the rest of Unit 3 accumulated at lower rates (see Sediment Accumulation Rates).

Sub-unit $3 \mathrm{~A}$ is interpreted as a volcanogenic altered ash deposit with intercalated pelagic calcareous biogenics. The variegated clays and silty clays of $3 \mathrm{~A}$ are megascopically similar to those of $3 \mathrm{C}$ and $3 \mathrm{E}$. Presumably, all three sub-units are mostly altered ash with the multitude of colors probably resulting from minor compositional differences, that is, concentrations of manganese oxides and the concentration and oxidation state of iron. Cross laminations, parallel laminations, and/or scour and fill structures are present in some of the variegated clays and silty clays of all three sub-units. This suggests that at least some of the beds were emplaced by local turbidity currents and/or reworked by bottom currents. The presence of significant amounts of mica/illite, chlorite, and kaolinite in certain portions of $3 \mathrm{~A}$ indicate periodic terrigenous input, although montmorillonite is dominant, indicating an overall volcanic origin for 3A. In addition, the fact that clays and silty clays contain sedimentary structures more characteristic of silty and sandy beds suggests that the beds originally were coarser ash. The ash presumably was emplaced and/or reworked by currents and then altered to clay minerals, with at least some of the sedimentary structures remaining intact. Many of the beds, however, show no indication of current activity and they may have accumulated by "pelagic" mechanisms.

The appreciable $\mathrm{CaCO}_{3}$ in $3 \mathrm{~A}$ suggests accumulation above the CCD. The abundance of altered ash in $3 \mathrm{~A}$ also suggests that Nashville Seamount was intermittently active during these declining stages of volcanism, or the ash may have been derived from a more distant source. The feldpathic and zeolitic stringers and interbeds of siltstone and sandstone, some of which are graded and 
have erosional basal contacts, were probably emplaced by turbidity currents originating on the slopes of Nashville Seamount. In summary, Sub-unit 3A probably resulted from (1) an accumulation of calcareous pelagic deposits, (2) a periodic influx of terrigenous clay, (3) a relatively more rapid accumulation of ash that intermittently diluted and sometimes masked the carbonate, and (4) an infrequent but rapid accumulation of thin, coarser interbeds.

The breccias and associated sandstones and siltstones of Sub-units 3B and 3F clearly are volcanogenic. The clasts in the breccias and lithic fragments in the coarser sandstones are altered vesicular basalt. The finer sandstones and siltstones contain (1) detrital crystals of feldspars, pyroxene, and amphibole that originally existed as phenocrysts in basalt and (2) detrital grains of calcite and zeolites that originally existed as amygdules and alteration products in basalt.

The poor sorting, clast angularity, cross bedding, and occasional graded bedding in the breccias and finer grained equivalents of Sub-units $3 \mathrm{~B}$ and $3 \mathrm{~F}$ suggest that they were probably emplaced by a slumping process, perhaps as a type of "fluxoturbidite" (Dzulynski, et al., 1959) initiated by volcanic activity or tectonism on Nashville Seamount. The extreme variability of alteration in adjacent breccia clasts requires differing exposure times to sea-floor alteration, indicating the clasts were remobilized from pre-existing volcanic units on the seamount. The seamount was probably never emergent or in shallow water long enough for reef formation. This is indicated by (1) a general lack of shallow-water fossils in Unit 3 (see Biostratigraphy) and (2) by recent ALVIN dives near the summit of Nashville Seamount that revealed no evidence of a flat top or a reef facies (Heirtzler et al., in press). The vesicularity of the basalt, however, suggests formation in a water depth of less than 1000 meters.

The calcareous interbeds in 3B could be pelagic carbonate deposits that were periodically interrupted by more rapid accumulation of volcaniclastics. However, cross laminations, parallel laminations, and scour and fill structures in some of the interbeds suggest they were emplaced by small turbidity currents and/or reworked by bottom currents. Thus, pelagic carbonate that accumulated on the steep flanks of Nashville Seamount may have been redeposited to form these beds.

Sub-units $3 \mathrm{C}$ and $3 \mathrm{E}$ also are interpreted as volcanogenic altered-ash deposits. The presence but relatively low abundance of $\mathrm{CaCO}_{3}$ suggests that ash was accumulating relatively rapidly on a sea floor near or below the CCD. The abundance of detrital zeolites and feldspars, the dilution of carbonate, and the presence of coarser stringers and interbeds (some graded) suggest emplacement, at least in part, by turbidity currents originating on the slopes of Nashville Seamount. In addition, some of the beds probably accumulated as ash-fall deposits. The clays in $3 \mathrm{E}$ are virtually all montmorillonite, suggesting a totally volcanogenic origin, whereas those in $3 \mathrm{C}$ contain about 25 per cent chlorite and kaolinite, suggesting at least some terrigenous input.
The lack of carbonate in Sub-unit 3D indicates that sediment in this interval accumulated below the CCD, perhaps at a relatively slow rate. The sub-unit may have formed in a "pelagic clay" depositional environment in which some volcanogenic material was also emplaced. The fact that the clay is virtually all montmorillonite also suggests a volcanogenic origin. The lack of coarse debris and the presence of much detrital feldspar and zeolite within both the finer grained major lithology and in silt and sand stringers and interbeds suggests that Nashville Seamount was largely inactive at this time and that weathering of previously erupted material provided the primary sediment source.

If the lack of calcareous interbeds in the breccia of $3 \mathrm{~F}$ is real and not the result of low core recovery in the $3 \mathrm{~F}$ interval, it suggests either that volcanic activity was nearly continuous rather than episodic at that time, or that the sea floor was below the CCD. The presence of epidote in $3 \mathrm{~F}$ breccia indicates hydrothermal activity after breccia deposition. Calcite in the matrix of $3 \mathrm{~B}$ and $3 \mathrm{~F}$ breccias may also have formed hydrothermally, or by low-temperature mobilization and recrystallization of carbonate from calcareous pelagic oozes that originally were mixed with the volcaniclastics. The zeolite cement in $3 \mathrm{~B}$ and $3 \mathrm{~F}$ probably is an alteration product of the basalt.

Certain aspects of the major lithologies of Unit 3 are compared in Table 3 and interpretations of Unit 3 are summarized in Table 4. Nashville Seamount underwent at least two major phases of volcanic and/or tectonic activity, represented by the two breccia sub-units. During the first phase (3F), the activity was relatively constant. As volcanic activity waned (3E, 3D), finer debris (ash) accumulated at Site 382 which probably was below the CCD. Carbonate in these three basal units may have been introduced from the shallower flanks of the seamount. Volcanic activity then began to increase (3C) and the sea floor was near the CCD, either because of uplift or because the CCD was deepening. The second major phase of volcanic activity resulted in the deposition of Sub-unit 3B breccias; deposition was episodic,

TABLE 3

Comparison of Certain Aspects of Major Lithologies in Unit 3 Subdivisions

\begin{tabular}{cccccc}
\hline $\begin{array}{c}\text { Sub- } \\
\text { Unit }\end{array}$ & $\begin{array}{c}\text { Grain } \\
\text { Size }\end{array}$ & $\begin{array}{c}\text { Carbonate } \\
\text { Content }\end{array}$ & $\begin{array}{c}\text { Zeolite } \\
\text { Content }\end{array}$ & $\begin{array}{c}\text { Relative } \\
\text { Accumulation } \\
\text { Rate }\end{array}$ & $\begin{array}{c}\text { Varie- } \\
\text { gated }\end{array}$ \\
\hline 3A & Fine & $\begin{array}{l}\text { High } \\
(10-40 \%)\end{array}$ & $\begin{array}{l}\text { Medium } \\
(2-4 \%)\end{array}$ & ? Medium & Yes \\
3B & Coarse & $\begin{array}{l}\text { High } \\
\text { (including } \\
\text { interbeds) }\end{array}$ & High & High & No \\
3C & Fine & Low (4\%) & $\begin{array}{l}\text { High } \\
(10 \%)\end{array}$ & ? Medium & Yes \\
3D & Fine & $\begin{array}{l}\text { Low } \\
(1-2 \%)\end{array}$ & $\begin{array}{l}\text { High } \\
(10 \%)\end{array}$ & ? Low & No \\
3E & Fine & Low (5\%) & $\begin{array}{l}\text { High } \\
(8 \%)\end{array}$ & ? Medium & Yes \\
3F & Coarse & High & High & High & No \\
\hline
\end{tabular}


TABLE 4

Interpretations Regarding Unit 3 Subdivisions

\begin{tabular}{cccccc}
\hline $\begin{array}{c}\text { Sub- } \\
\text { Unit }\end{array}$ & $\begin{array}{c}\text { Relative Activity } \\
\text { of Nashville } \\
\text { Seamount }\end{array}$ & $\begin{array}{c}\text { Relative Amount of } \\
\text { Pelagic Biogenic } \\
\text { Carbonate }\end{array}$ & $\begin{array}{c}\text { Relative Amount of } \\
\text { Detrital Carbonate }\end{array}$ & $\begin{array}{c}\text { Sea Floor } \\
\text { Relative to } \\
\text { CCD }\end{array}$ & $\begin{array}{c}\text { Altered Ash } \\
\text { Relative Content }\end{array}$ \\
\hline 3A & Medium & High & Low & Above & Medium to high \\
3B & High & High & ? High & Above & Low \\
3C & Medium & Low & Low & Near, probably & Medium \\
& Low & Lowest & Lowest & Below & High \\
3D & Low & Low & Low & Below & High \\
3E & Medium & Low & $?$ & $?$ & Low \\
3F & High & & & & \\
\hline
\end{tabular}

and beds of pelagic limestone accumulated between rapidly emplaced breccias. Volcanic activity again began to wane during the accumulation of $3 \mathrm{~A}$. The sea floor was near, but almost certainly above the CCD. After the 50-million year hiatus separating Units 3 and 2 , the sea floor was again below the CCD, and it has remained so since the early Miocene.

\section{GEOCHEMISTRY}

\section{Carbon, Nitrogen}

To monitor the abundance of organic matter in sediments recovered during Leg 43, a shipboard Hewlett-Packard Model 185-B CHN Analyzer was used to determine the organic carbon and nitrogen contents of sediment samples. Prior to analysis, samples were treated with $3 N$ hydrochloric acid to remove calcium carbonate, and the change in sample weight after acid treatment was measured so that the results could be expressed in terms of the original sample weight. National Bureau of Standards organic compounds were used to calibrate the instrument. Replicate analyses indicate that the precision of the measurements was about \pm 10 per cent of the value measured.

The seven sediment samples from Site $\mathbf{3 8 2}$ analyzed onboard ship, as well as those analyzed in the shore laboratory (Cameron, this volume), are low in organic carbon, with values ranging from 0.1 to 0.4 per cent (Table 5, Figure 8). $\mathrm{C} / \mathrm{N}$ ratios are also low, averaging about 5. Stevenson and Cheng (1972) report that C/N ratios of 5 are low, but not unusual, for deep-sea

TABLE 5

Shipboard Organic Carbon, Nitrogen Measurements, Site 382

\begin{tabular}{lcccc}
\hline $\begin{array}{c}\text { Sample } \\
\text { (Interval in cm) }\end{array}$ & $\begin{array}{c}\text { Depth Below } \\
\text { Sea Floor } \\
(\mathrm{m})\end{array}$ & $\% \mathrm{C}_{\text {org }}$ & $\% \mathrm{~N}$ & $\frac{\mathrm{C}}{\mathrm{N}}$ \\
\hline $1-4,150$ & 56.7 & 0.3 & 0.06 & 5 \\
$2-2,20-21$ & 108.9 & 0.3 & 0.05 & 6 \\
$5-2,130$ & 233.8 & 0.1 & 0.03 & 3 \\
$6-4,150$ & 256.1 & 0.4 & 0.08 & 5 \\
$7-0,0$ & 269.1 & 0.4 & 0.07 & 6 \\
$12-4,130$ & 322.6 & 0.2 & 0.04 & 5 \\
$14-5,130$ & 343.1 & 0.1 & 0.04 & 3 \\
\hline
\end{tabular}

sediments. They also note, however, that a significant fraction of the nitrogen in sediments that contain small amounts of organic carbon may be inorganic nitrogen bound in the lattices of clay minerals. As a consequence, $\mathrm{C} / \mathrm{N}$ ratios may not accurately reflect the composition of organic matter in the sediments of Site 382 .

\section{Calcium Carbonate}

Shipboard calcium carbonate determinations were made using the "Carbonate Bomb." A gage mounted on a plexiglas pressure vessel measures the pressure generated when concentrated hydrochloric acid is reacted with the sediment sample. The pressure readings are converted to weight per cent $\mathrm{CaCO}_{3}$, using a calibration curve constructed by reacting known amounts of $\mathrm{CaCO}_{3}$.

The results of shipboard carbonate bomb measurements (Table 6) and laboratory analyses (see Cameron, this volume) show that the Campanian sediments are significantly more calcareous (30 to $60 \%$ $\mathrm{CaCO}_{3}$ ) than the overlying Cenozoic sediments (less than $10 \% \mathrm{CaCO}_{3}$ ) (Figure 8). The higher carbonate content of the Cretaceous sediments probably reflects slumping from the shallower flanks of Nashville Seamount and, at least in the late Campanian, pelagic accumulation above a deepening CCD (see Tucholke and Vogt, this volume).

\section{Interstitial Water Chemistry}

Seven sediment samples were collected for analysis of the interstitial waters. The results of these measurements (Table 7, Figure 9) indicate that chlorinity, $p \mathrm{H}, \mathrm{Ca}^{++}$, and $\mathrm{Mg}^{++}$remain generally constant with depth, while salinity increases slightly. Alkalinity decreases markedly from $10.5 \mathrm{meq} / \mathrm{l}$ near the surface to about $1.5 \mathrm{meq} / \mathrm{l}$ at a depth of 400 meters. Sayles and Manheim (1975) have noted that high alkalinities are commonly observed in rapidly deposited terrigenous sediments.

\section{PHYSICAL PROPERTIES}

\section{Introduction}

At Site 382 the physical properties determined include wet bulk density, undrained shear strength (un- 
TABLE 6

Shipboard $\mathrm{CaCO}_{3}$ Measurementsa, Site 382

\begin{tabular}{|c|c|c|}
\hline $\begin{array}{c}\text { Sample } \\
\text { (Interval in } \mathrm{cm} \text { ) }\end{array}$ & $\begin{array}{l}\text { Depth Below } \\
\text { Sea Floor } \\
\text { (m) }\end{array}$ & $\% \mathrm{CaCO}_{3}$ \\
\hline $\begin{array}{l}1-1,52-53 \\
2-2,19-20 \\
2-3,83-84 \\
3-2,119-120 \\
4-1,40-41\end{array}$ & $\begin{array}{r}51.2 \\
108.9 \\
111.0 \\
176.7 \\
202.9\end{array}$ & $\begin{array}{r}5 \\
13 \\
4 \\
3 \\
6\end{array}$ \\
\hline $\begin{array}{l}5-2,80-81 \\
5-3,27-28 \\
5-4,78-79 \\
6-1,65-66 \\
6-2,79-80\end{array}$ & $\begin{array}{l}233.3 \\
234.3 \\
236.3 \\
250.8 \\
252.4\end{array}$ & $\begin{array}{l}0 \\
4 \\
0 \\
1 \\
0\end{array}$ \\
\hline $\begin{array}{l}8-2,54-55 \\
9-4,141-142 \\
17-1,74-75 \\
17-2,73-75 \\
17-3,30-31\end{array}$ & $\begin{array}{l}280.6 \\
294.1 \\
365.1 \\
366.6 \\
367.7\end{array}$ & $\begin{array}{r}27 \\
19 \\
48 \\
44 \\
5\end{array}$ \\
\hline $\begin{array}{l}17-3,78-80 \\
17-4,45-46 \\
17-4,103-105 \\
18-1,60-65 \\
18-2,145-147\end{array}$ & $\begin{array}{l}368.2 \\
369.4 \\
369.9 \\
374.4 \\
376.8\end{array}$ & $\begin{array}{r}45 \\
53 \\
14 \\
7 \\
8\end{array}$ \\
\hline $\begin{array}{l}18-3,46-49 \\
18-4,148-150 \\
19-2,45-50 \\
19-2,71-77 \\
19-3,38-41\end{array}$ & $\begin{array}{l}377.3 \\
379.8 \\
385.3 \\
385.5 \\
386.7\end{array}$ & $\begin{array}{r}7 \\
37 \\
10 \\
30 \\
40\end{array}$ \\
\hline $\begin{array}{l}19-3,71-76 \\
19-3,145-150 \\
19-4,0-5 \\
19-4,88-92 \\
20-2,20-22\end{array}$ & $\begin{array}{l}387.0 \\
387.8 \\
387.8 \\
388.7 \\
404.0\end{array}$ & $\begin{array}{r}0 \\
46 \\
57 \\
57 \\
30\end{array}$ \\
\hline $\begin{array}{l}20-2,97-98 \\
20-2,103-104 \\
20-3,50-51 \\
20-4,64-66 \\
20-5,106-107\end{array}$ & $\begin{array}{l}404.8 \\
404.8 \\
405.8 \\
407.4 \\
409.4\end{array}$ & $\begin{array}{r}29 \\
4 \\
3 \\
5 \\
4\end{array}$ \\
\hline
\end{tabular}

${ }^{\mathrm{a}}$ Carbonate bomb method. Additional shore-lab data are given by Koch and Rothe (this volume) and Cameron (this volume).

disturbed and remolded), compressional wave velocity, thermal conductivity, and bulk properties such as water content, porosity, and grain density. These data are presented in Table 8. The shipboard techniques for determining these properties are listed below together with the approximate system errors associated with each measuring technique (Bennett and Keller, 1973; Lee, 1973; Boyce, 1974; and Rocker, 1974).

a) The Gamma Ray Attenuation Porosity Evaluator (GRAPE) was used to determine wet bulk density and porosity. GRAPE was used for each core in the continuous operation mode $( \pm 5 \%)$ and it was used periodically as a check on the density of hard specimens by taking special two-minute counts $( \pm 2 \%)$.

b) Syringe, cylinder, and rock-chunk specimens with a volume of 3 to $5 \mathrm{cc}$ or more were used to obtain water contents $( \pm 2 \%)$. Because the initial specimen volume

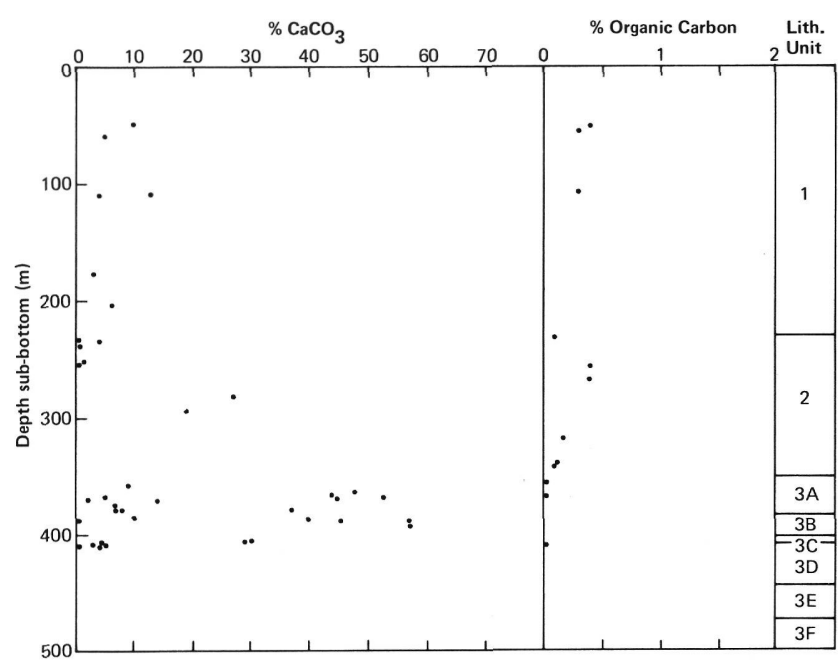

Figure 8. Relative abundance of organic carbon and calcium carbonate in sediments at Site 382, based on shipboard measurements (Tables 5, 6) and data from Kendrick; Koch and Rothe; and Cameron (all in this volume).

was measured, it was possible to calculate the wet bulk density, porosity, and grain density. The errors associated with each of these measurements is about $\pm 5 \%$ for syringe specimens and $\pm 2 \%$ for rock-chunk specimens. Adjustments for salt were not made in the calculations.

c) The Hamilton-Frame velocimeter was used to measure compressional wave velocities $( \pm 2 \%)$ of sediment and rock specimens. Velocities both perpendicular and parallel to the bedding planes were obtained but only values perpendicular to bedding were used to compute impedance.

d) A laboratory vane shear apparatus was used for the undisturbed and remolded, undrained shear strengths $( \pm 2 \%)$. The $1 / 2 \times 1 / 2$ in. vane was rotated at an angular velocity of about $60^{\circ}$ per minute and remolding was accomplished by three complete rotations of the vane.

e) The JOIDES Digital Thermal Conductivity Measuring System provided conductivity data $( \pm 2 \%)$. The digitized data will be processed at a shore laboratory and reported in a later volume (A. Erickson, personal communication, 1976); therefore, only the core test sections are noted in Table 8.

Perhaps more severe than the systems errors are the errors induced by coring disturbance and sample heterogeneity. For example, a fragmented stiff clay or rock of nonuniform diameter may have a GRAPE density (continuous mode) which is 10 to 15 per cent lower than its in-situ value, and undisturbed vane shear strengths may be low by 100 per cent or more. Further complicating factors are the release of hydrostatic pressures and changes in temperature and effective overburden pressures which may result in increased specimen volumes and the release of dissolved gases within core specimens. The influence of unloading and temperature are considered further by Demars et al. 
TABLE 7

Interstitial Water Chemistry, Site 382

\begin{tabular}{lccccccc}
\hline $\begin{array}{c}\text { Sample } \\
\text { (Interval in cm) }\end{array}$ & $\begin{array}{c}\text { Depth Below } \\
\text { Sea Floor } \\
(\mathrm{m})\end{array}$ & $p \mathrm{H}$ & $\begin{array}{c}\text { Alkalinity } \\
(\mathrm{m}) \mathrm{f} / \mathrm{l})\end{array}$ & $\begin{array}{c}\text { Salinity } \\
(\% \mathrm{o})\end{array}$ & $\begin{array}{c}\text { Chlorinity } \\
(\% \mathrm{oo})\end{array}$ & $\begin{array}{c}\mathrm{Ca}^{++} \\
(\mathrm{m} \mathrm{mole} / \mathrm{l})\end{array}$ & $\begin{array}{c}\mathrm{Mg}^{++} \\
(\mathrm{m} \mathrm{mole} / \mathrm{l})\end{array}$ \\
\hline $1-5,144-150$ & 58.6 & 8.06 & 10.5 & 33.0 & 19.3 & 6.0 & 45.2 \\
$2-2,144-150$ & 111.0 & 8.19 & 9.62 & 32.7 & 18.9 & 5.5 & 36.5 \\
$5-3,140-150$ & 235.5 & 8.46 & 7.35 & 33.8 & 19.6 & 9.0 & 46.5 \\
$12-5,144-150$ & 324.3 & 7.94 & 3.82 & 34.4 & 19.0 & 12.2 & 47.8 \\
$13-4,140-150$ & 332.3 & 8.06 & 3.58 & 33.8 & 19.0 & 12.1 & 47.9 \\
$17-4,140-150$ & 370.4 & 7.85 & 2.40 & 34.1 & 19.1 & 11.7 & 48.9 \\
$20-4,140-150$ & 408.3 & 8.18 & 1.56 & 34.6 & 18.9 & 12.1 & 48.1 \\
\hline
\end{tabular}

(this volume). To minimize disturbance effects, only cohesive test specimens with minimum visual distortion were selected for physical property measurements other than the continuous GRAPE. Thus the data presented in Table 8 are adequate for examining physical property trends with sub-bottom depth; however, the measured values may differ significantly from in-situ values.

\section{Shear Strength}

The variation in undrained shear strength with depth is presented in Figure 10. In general, shear strength increases linearly to a sub-bottom depth of about 200 meters, which is compatible with the expected trend. Below this depth, the clay was brittle and either vane insertion or rotation caused the specimens to crack. As a result, the shear strengths below 200 meters are very erratic. Vane shear tests were not made for samples from depths greater than about 275 meters sub-bottom.

\section{Bulk Properties}

Water content data from the syringe and rock chunk techniques are shown in Figure 11 and it is noted that porosity would provide a similar trend because of its phase relationship. Water contents as per cent of wet weight average about 28 per cent and range from 22 to 36 per cent. In the upper 200 meters the water contents appear to decrease with depth; this agrees with the trend observed for shear strength.

\section{Density and Acoustic Velocity}

Wet bulk density, acoustic velocity, and impedance (product of density times velocity) also are presented in Figure 11 . Wet bulk density remains approximately constant at $1.85 \mathrm{~g} / \mathrm{cc}$ to a sub-bottom depth of about 380 meters, where a layer of basalt breccia and marly limestone was encountered with a density of $2.2 \mathrm{~g} / \mathrm{cc}$. Below the thin breccia layer the density of a compacted claystone continues at about $1.9 \mathrm{~g} / \mathrm{cc}$ until a second, thicker cemented breccia layer is encountered at about 475 meters. This second breccia layer has a density of $2.2 \mathrm{~g} / \mathrm{cc}$ and greater. In general, the acoustic velocity increases only slightly with depth in clay, averaging about $1.65 \mathrm{~km} / \mathrm{sec}$. The two breccia layers have acoustic velocities between 3 and $4 \mathrm{~km} / \mathrm{sec}$, whereas the interbedded

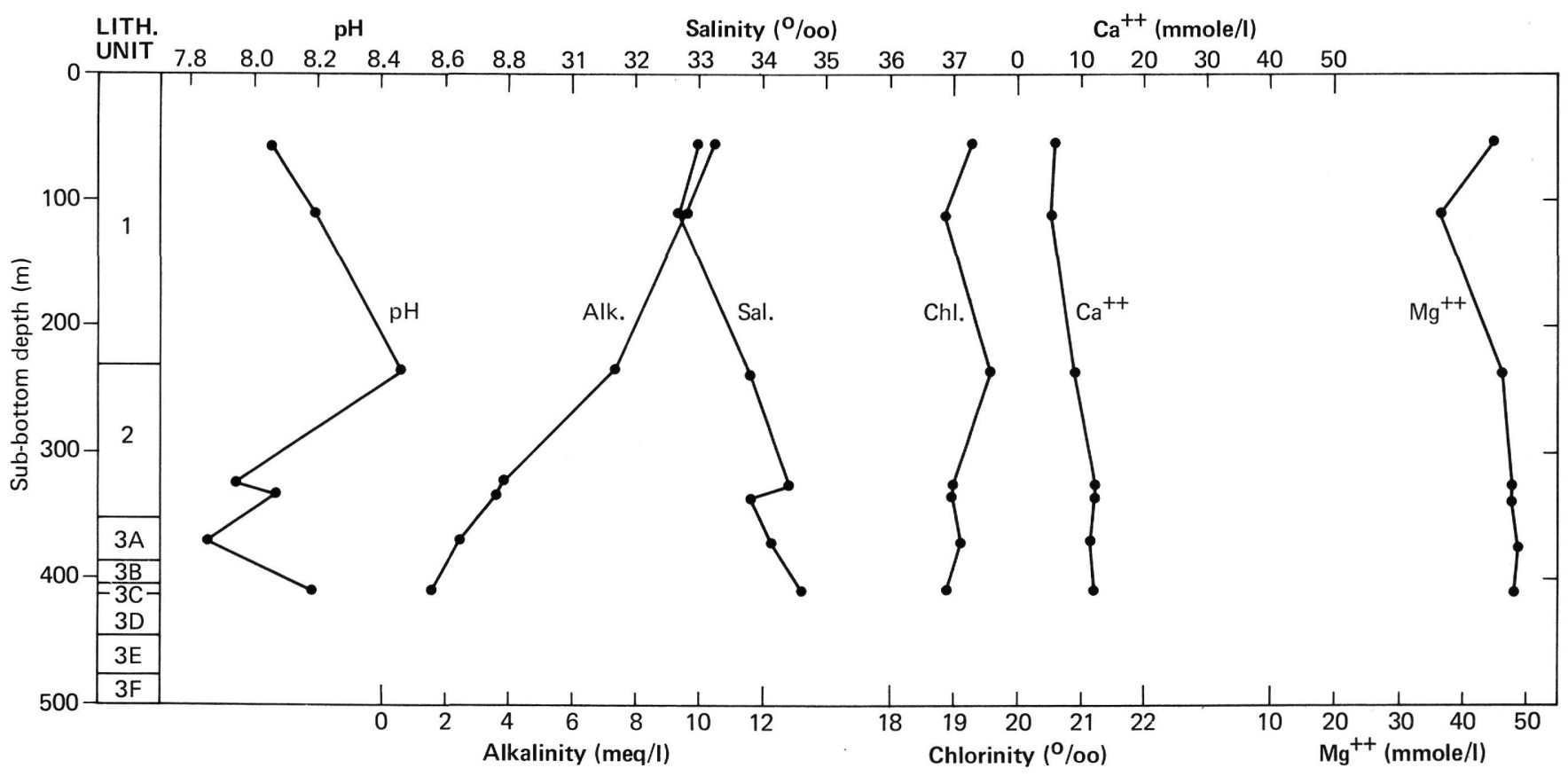

Figure 9. Interstitial water chemistry versus depth at Site 382. 
TABLE 8

Physical Properties Data, Site 382

\begin{tabular}{|c|c|c|c|c|c|c|c|c|c|c|c|c|c|c|c|}
\hline \multirow[b]{3}{*}{$\begin{array}{c}\text { Sample } \\
\text { (Interval in } \mathrm{cm} \text { ) }\end{array}$} & \multirow[b]{3}{*}{$\begin{array}{l}\text { Sub-Bottom } \\
\text { Depth (m) }\end{array}$} & \multirow{2}{*}{\multicolumn{2}{|c|}{$\begin{array}{l}\text { Velocity } \\
(\mathrm{km} / \mathrm{sec})\end{array}$}} & \multirow{2}{*}{\multicolumn{2}{|c|}{\begin{tabular}{|c} 
GRAPE \\
Special \\
$\begin{array}{c}\text { 2-minute } \\
\text { Count }\end{array}$ \\
$\begin{array}{c}\text { W. B. Den. } \\
\left(\mathrm{g} / \mathrm{cm}^{3}\right)\end{array}$
\end{tabular}}} & \multirow{2}{*}{\multicolumn{2}{|c|}{$\begin{array}{l}\text { GRAPE } \\
\text { Routine }^{\mathrm{a}, \mathrm{b}}\end{array}$}} & \multirow{3}{*}{ 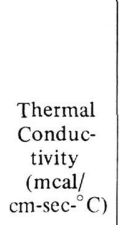 } & \multirow{3}{*}{$\begin{array}{l}\text { Shear } \\
\text { Strength } \\
\text { Undist/ } \\
\text { Rem. } \\
\left(\mathrm{g} / \mathrm{cm}^{2}\right)\end{array}$} & \multirow{2}{*}{\multicolumn{4}{|c|}{ Syringe or Rock Chunk }} & \multirow[b]{3}{*}{$\begin{array}{c}\text { Impedance } \\
\left(\mathrm{g} / \mathrm{cm}^{2}-\right. \\
\mathrm{sec}) \times 10^{5}\end{array}$} & \multirow[b]{3}{*}{ Lithology } \\
\hline & & & & & & & & & & & & & & & \\
\hline & & $\begin{array}{l}\quad(\mathrm{km} / \\
\text { Para. } \\
\text { Beds }\end{array}$ & $\begin{array}{l}\text { sec) } \\
\text { Perp. } \\
\text { Beds }\end{array}$ & $\begin{array}{l}\quad(g / c 1 \\
\text { Para. } \\
\text { Beds }\end{array}$ & $\begin{array}{l}\left.\mathrm{m}^{3}\right) \\
\text { Perp. } \\
\text { Beds }\end{array}$ & $\begin{array}{l}\text { W. B. } \\
\text { Den. } \\
\left(\mathrm{g} / \mathrm{cm}^{3}\right)\end{array}$ & $\begin{array}{l}\text { Por. } \\
(\%)\end{array}$ & & & $\begin{array}{l}\text { Water } \\
\text { Cont. } \\
(\%)\end{array}$ & $\begin{array}{l}\text { Grain } \\
\text { Dens. } \\
\left(\mathrm{g} / \mathrm{cm}^{3}\right)\end{array}$ & $\begin{array}{l}\text { Wet Bulk } \\
\text { Den. } \\
\left(\mathrm{g} / \mathrm{cm}^{3}\right)\end{array}$ & $\begin{array}{l}\text { Por. } \\
(\%)\end{array}$ & & \\
\hline $\begin{array}{l}1-2,113-114 \\
1-4,30-32 \\
1-4,37-38 \\
1-4,143-144 \\
1-6,64-65\end{array}$ & $\begin{array}{l}53.3 \\
55.5 \\
55.6 \\
56.6 \\
58.8\end{array}$ & $\begin{array}{l}1.53 \\
1.52\end{array}$ & & & & $\begin{array}{l}1.70 \\
1.87 \\
1.87 \\
1.87 \\
1.91\end{array}$ & $\begin{array}{l}58 \\
48 \\
48 \\
48 \\
45\end{array}$ & & \begin{tabular}{|c|}
\multicolumn{1}{|c}{$30 / 14$} \\
\\
$227 / 44$ \\
$334 / 114$
\end{tabular} & $\begin{array}{l}33 \\
32\end{array}$ & 2.48 & $\begin{array}{l}1.89 \\
1.68\end{array}$ & $\begin{array}{l}62 \\
54\end{array}$ & $\begin{array}{l}2.95^{\mathrm{d}} \\
2.99^{\mathrm{d}}\end{array}$ & $\begin{array}{l}\text { Sticky gray clay } \\
\text { Silty clay } \\
\text { Silty clay } \\
\text { Silty clay } \\
\text { Silty clay }\end{array}$ \\
\hline $\begin{array}{l}1-6,146-147 \\
2-3,30-31 \\
2-3,35-38 \\
2-3,41-42 \\
3-2,50-52\end{array}$ & $\begin{array}{r}59.7 \\
110.5 \\
110.6 \\
110.6 \\
176.0\end{array}$ & 1.65 & 1.65 & 2.00 & 2.03 & $\begin{array}{l}1.91 \\
2.01 \\
2.01 \\
2.01 \\
1.89\end{array}$ & $\begin{array}{l}45 \\
40 \\
40 \\
40 \\
47\end{array}$ & & $\begin{array}{l}626 / 241 \\
517 / \\
821 / 70\end{array}$ & $\begin{array}{l}33 \\
23\end{array}$ & $\begin{array}{l}2.67 \\
2.80\end{array}$ & $\begin{array}{l}1.72 \\
1.99\end{array}$ & $\begin{array}{l}57 \\
45\end{array}$ & $3.32^{\mathrm{d}}$ & $\begin{array}{l}\text { Silty clay } \\
\text { Silty clay } \\
\text { Silty clay } \\
\text { Silty clay } \\
\text { Silty clay }\end{array}$ \\
\hline $\begin{array}{l}3-2,53-55 \\
4-1,45-56 \\
4-1,108-120 \\
4-1,136-144 \\
5-2,24-30\end{array}$ & $\begin{array}{l}176.0 \\
203.0 \\
203.6 \\
203.9 \\
232.8\end{array}$ & $\begin{array}{l}1.61 \\
1.61 \\
1.57\end{array}$ & 1.57 & $\begin{array}{l}2.09 \\
1.84\end{array}$ & & 1.89 & 47 & & \begin{tabular}{|l|}
$770 / 97$ \\
$421 / 139$ \\
$793 / 93$ \\
$770 /$
\end{tabular} & $\begin{array}{l}22 \\
29 \\
32\end{array}$ & $\begin{array}{l}2.58 \\
2.80\end{array}$ & $\begin{array}{l}1.91 \\
1.89 \\
1.92\end{array}$ & $\begin{array}{l}42 \\
68 \\
61\end{array}$ & $\begin{array}{l}3.09 \\
2.96^{\mathrm{d}} \\
2.51^{\mathrm{d}}\end{array}$ & $\begin{array}{l}\text { Silty clay } \\
\text { Clay } \\
\text { Sand } \\
\text { Clay } \\
\text { Clay }\end{array}$ \\
\hline $\begin{array}{l}5-2,33-34 \\
5-3,30-31 \\
5-3,73-74 \\
5-3,93-105 \\
5-4,23-24\end{array}$ & $\begin{array}{l}232.8 \\
234.3 \\
234.7 \\
235.0 \\
235.7\end{array}$ & & & & & 1.59 & 66 & & $\begin{array}{l}751 / 167 \\
454 / \\
723 / \\
909 /\end{array}$ & 29 & $\begin{array}{l}2.81 \\
2.81\end{array}$ & $\begin{array}{l}1.85 \\
1.86\end{array}$ & $\begin{array}{l}53 \\
53\end{array}$ & & $\begin{array}{l}\text { Clay } \\
\text { Clay } \\
\text { Clay } \\
\text { Clay } \\
\text { Clay }\end{array}$ \\
\hline $\begin{array}{l}5-4,45-46 \\
5-4,48-49 \\
5-4,72-73 \\
6-3,81-82 \\
6-3,148-149\end{array}$ & $\begin{array}{l}235.9 \\
236.0 \\
236.2 \\
254.4 \\
255.0\end{array}$ & 1.63 & $\begin{array}{l}1.61 \\
1.66\end{array}$ & & 1.94 & $\begin{array}{l}1.82 \\
1.82 \\
1.82\end{array}$ & $\begin{array}{l}51 \\
51 \\
51\end{array}$ & & $\begin{array}{l}1280 / \\
807 /\end{array}$ & & & & & $3.12^{\mathrm{d}}$ & $\begin{array}{l}\text { Clay } \\
\text { Clay } \\
\text { Clay } \\
\text { Clay } \\
\text { Clay }\end{array}$ \\
\hline $\begin{array}{c}6-5,19,60 \\
96,126 \\
6-6,120-125 \\
7-2,28-35 \\
7-4,24,55 \\
100,132 \\
7-6,38-39\end{array}$ & $\begin{array}{l}256.6- \\
258.0 \\
259.3 \\
271.2 \\
274.0- \\
275.3 \\
277.2\end{array}$ & 1.65 & $\begin{array}{l}1.63 \\
1.62\end{array}$ & & & $\begin{array}{l}1.85 \\
\\
1.84 \\
1.76 \\
1.87 \\
1.88\end{array}$ & $\begin{array}{l}49 \\
\\
50 \\
55 \\
48 \\
\\
48\end{array}$ & $\mathrm{X}$ & $\begin{array}{l}2359 / \\
3223 /\end{array}$ & $\begin{array}{l}28 \\
30\end{array}$ & $\begin{array}{l}3.00 ? \\
2.72\end{array}$ & $\begin{array}{l}1.93 \\
1.81\end{array}$ & $\begin{array}{l}54 \\
53\end{array}$ & $\begin{array}{l}3.15 \\
2.93 \\
\\
3.22^{\mathrm{d}}\end{array}$ & $\begin{array}{l}\text { Clay } \\
\text { Clay } \\
\text { Clay } \\
\text { Clay } \\
\text { Clay }\end{array}$ \\
\hline $\begin{array}{r}8-3,39-44 \\
8-4,20,58 \\
99,134 \\
8-6,62-68 \\
9-3,65-66 \\
9-4,19,48 \\
101,137\end{array}$ & $\begin{array}{l}282.5 \\
283.6- \\
285.0 \\
287.2 \\
291.8 \\
292.8- \\
294.1\end{array}$ & 1.67 & $\begin{array}{l}1.64 \\
1.65\end{array}$ & & & $\begin{array}{l}1.82 \\
1.84 \\
\\
\\
1.71 \\
1.86 \\
1.85\end{array}$ & $\begin{array}{l}51 \\
50 \\
\\
58 \\
49 \\
49\end{array}$ & $\mathrm{X}$ & & 29 & 2.59 & 1.80 & 52 & $\begin{array}{l}2.95 \\
3.15^{d}\end{array}$ & $\begin{array}{l}\text { Clay } \\
\text { Clay } \\
\text { Clay } \\
\text { Clay } \\
\text { Clay }\end{array}$ \\
\hline $\begin{array}{l}9-6,40-44 \\
10-2,20,55 \\
100,136 \\
11-3,38-43 \\
11-4,134 \\
11-6,148-149\end{array}$ & $\begin{array}{l}296.1 \\
299.3- \\
300.6 \\
311.2 \\
313.5 \\
316.8\end{array}$ & & $\begin{array}{l}1.67 \\
1.67\end{array}$ & & 1.94 & $\begin{array}{l}1.80 \\
1.77 \\
\\
\\
1.83 \\
1.83 \\
1.84\end{array}$ & $\begin{array}{l}52 \\
54 \\
\\
50 \\
51 \\
50\end{array}$ & $\mathrm{X}$ & & 28 & 2.59 & 1.79 & 51 & $\begin{array}{l}2.99 \\
3.24^{\mathrm{d}}\end{array}$ & $\begin{array}{l}\text { Clay } \\
\text { Clay } \\
\text { Clay } \\
\text { Clay } \\
\text { Clay }\end{array}$ \\
\hline $\begin{array}{c}12-3,93-94 \\
12-6,25,52 \\
90,122 \\
13-6,146-147 \\
14-3,30,60 \\
90,120 \\
15-2,36-37\end{array}$ & $\begin{array}{l}321.2 \\
324.9- \\
326.2 \\
335.7 \\
339.4- \\
340.7 \\
347.8\end{array}$ & 1.67 & 1.71 & 1.85 & 1.87 & $\begin{array}{l}1.72 \\
1.74 \\
\\
1.70 \\
1.75 \\
\\
1.74\end{array}$ & $\begin{array}{l}57 \\
56 \\
\\
59 \\
56 \\
\\
56\end{array}$ & $\begin{array}{l}\mathrm{X} \\
\mathrm{X} \\
\mathrm{X}\end{array}$ & & & & & & $\begin{array}{l}3.02^{\mathrm{d}} \\
2.87^{\mathrm{d}} \\
3.16^{\mathrm{d}}\end{array}$ & $\begin{array}{l}\text { Clay } \\
\text { Clay } \\
\text { Clay } \\
\text { Clay } \\
\text { Clay }\end{array}$ \\
\hline $\begin{array}{l}15-4,30,60 \\
90,120 \\
15-5,92-93 \\
15-6,127-128 \\
16-2,145-146 \\
16-5,135\end{array}$ & $\begin{array}{l}350.5- \\
351.8 \\
352.8 \\
354.8 \\
358.2 \\
362.6\end{array}$ & & $\begin{array}{l}1.66 \\
1.64 \\
1.67 \\
1.68\end{array}$ & 1.52 & $\begin{array}{l}1.87 \\
1.77\end{array}$ & $\begin{array}{l}1.77 \\
\\
1.81 \\
1.84 \\
1.69 \\
1.66\end{array}$ & $\begin{array}{l}54 \\
52 \\
50 \\
59 \\
61\end{array}$ & $X$ & & 36 & & $\begin{array}{l}1.68 \\
1.68\end{array}$ & $\begin{array}{l}62 \\
61\end{array}$ & $\begin{array}{l}3.10^{\mathrm{d}} \\
3.12^{\mathrm{d}} \\
2.81 \\
2.82\end{array}$ & $\begin{array}{l}\text { Clay } \\
\text { Clay } \\
\text { Clay } \\
\text { Clay } \\
\text { Clay }\end{array}$ \\
\hline $\begin{array}{l}16-6,90-91 \\
16, \mathrm{CC} \\
17-4,36-37 \\
17-5,24,94 \\
104,130 \\
17-6,64-65\end{array}$ & $\begin{array}{l}363.6 \\
364.3 \\
369.3 \\
370.5- \\
371.8 \\
372.5\end{array}$ & $\begin{array}{l} \\
-1.6 \\
-1.6\end{array}$ & $\begin{array}{l}1.63 \\
8- \\
1-\end{array}$ & & 1.82 & $\begin{array}{l}1.60 \\
\\
1.71 \\
1.66 \\
\\
1.62\end{array}$ & $\begin{array}{l}65 \\
58 \\
61 \\
63\end{array}$ & $\mathrm{X}$ & & 36 & & 1.72 & 61 & $\begin{array}{l}2.77^{\mathrm{d}} \\
2.91^{\mathrm{d}} \\
3.23\end{array}$ & $\begin{array}{l}\text { Banded clay } \\
\text { Clay } \\
\text { Banded clay } \\
\text { Clay and marly ooze } \\
\text { Red clay }\end{array}$ \\
\hline $\begin{array}{c}18-1,75-76 \\
18-2,30,55 \\
89,137 \\
19-2,15-16 \\
19-2,37-38 \\
19-2,112-113\end{array}$ & $\begin{array}{l}374.6 \\
375.4- \\
376.7 \\
385.0 \\
385.2 \\
385.9\end{array}$ & $\begin{array}{l}1.82 \\
\\
1.76 \\
3.21 \\
3.00\end{array}$ & $\begin{array}{l}1.77 \\
2.92\end{array}$ & & 1.82 & $\begin{array}{l}1.64 \\
1.67 \\
\\
1.69 \\
1.69 \\
1.69\end{array}$ & $\begin{array}{l}62 \\
60 \\
\\
59 \\
59 \\
59\end{array}$ & $\mathrm{X}$ & & & & & & $\begin{array}{l}3.22^{\mathrm{d}} \\
\\
3.08^{\mathrm{d}} \\
5.59^{\mathrm{d}} \\
5.08^{\mathrm{d}}\end{array}$ & $\begin{array}{l}\text { Red silty claystone } \\
\text { Silty clay, siltstone } \\
\text { Calc. silty claystone } \\
\text { Siltstone } \\
\text { Breccia }\end{array}$ \\
\hline $\begin{array}{l}19-3,75-76 \\
19-4,4-5 \\
19-4,12-13 \\
19-4,55-56 \\
19, \text { CC, Top }\end{array}$ & $\begin{array}{c}387.1 \\
387.8 \\
387.9 \\
388.4 \\
(389.4)\end{array}$ & $\begin{array}{l}3.32 \\
4.34 \\
3.32 \\
3.04 \\
3.16\end{array}$ & & & 2.18 & $\begin{array}{l}1.82 \\
1.82 \\
1.82 \\
1.82\end{array}$ & $\begin{array}{l}51 \\
51 \\
51 \\
51\end{array}$ & . & & & & & & $\begin{array}{l}6.21^{\mathrm{d}} \\
8.07 \mathrm{~d} \\
6.18^{\mathrm{d}} \\
5.65^{\mathrm{d}} \\
6.89^{\mathrm{d}}\end{array}$ & $\begin{array}{l}\text { Breccia } \\
\text { Calcite-cemented breccia } \\
\text { Breccia } \\
\text { Breccia } \\
\text { Breccia }\end{array}$ \\
\hline
\end{tabular}


TABLE 8 - Continued

\begin{tabular}{|c|c|c|c|c|c|c|c|c|c|c|c|c|c|c|c|}
\hline \multirow{2}{*}{$\begin{array}{c}\text { Sample } \\
\text { (Interval in } \mathrm{cm} \text { ) }\end{array}$} & \multirow{2}{*}{$\begin{array}{l}\text { Sub-Bottom } \\
\text { Depth (m) }\end{array}$} & \multirow{2}{*}{\multicolumn{2}{|c|}{$\begin{array}{l}\text { Velocity } \\
(\mathrm{km} / \mathrm{sec})\end{array}$}} & \multirow{2}{*}{\multicolumn{2}{|c|}{$\begin{array}{c}\text { GRAPE } \\
\text { Special } \\
\text { 2-minute } \\
\text { Count }\end{array}$}} & \multirow{2}{*}{\multicolumn{2}{|c|}{$\begin{array}{c}\text { GRAPE } \\
\text { Routine }^{\mathrm{a}, \mathrm{b}}\end{array}$}} & \multirow{2}{*}{$\begin{array}{c}\text { Thermal } \\
\text { Conduc- } \\
\text { tivity } \\
\text { (mcal/ } \\
\left.\text { cm-sec- }^{-} \mathrm{C}\right)\end{array}$} & \multirow{2}{*}{$\begin{array}{l}\text { Shear } \\
\text { Strength } \\
\text { Undist/ } \\
\text { Rem. } \\
\left(\mathrm{g} / \mathrm{cm}^{2}\right)\end{array}$} & \multirow{2}{*}{\multicolumn{4}{|c|}{ Syringe or Rock Chunk }} & \multirow{2}{*}{$\begin{array}{l}\text { Impedance } \\
\left(\mathrm{g} / \mathrm{cm}^{2}-\right. \\
\mathrm{sec}) \times 10^{5}\end{array}$} & \multirow{2}{*}{ Lithology } \\
\hline & & & & & & & & & & & & & & & \\
\hline $\begin{array}{l}20-3,32-33 \\
20-3,102-103 \\
21-3,67-68 \\
22-2,110-111 \\
22-3,148-149\end{array}$ & $\begin{array}{l}405.6 \\
406.3 \\
415.4 \\
442.9 \\
444.8\end{array}$ & 2.07 & $\begin{array}{l}1.91 \\
1.89 \\
1.98 \\
2.07 \\
1.84\end{array}$ & & $\begin{array}{l}1.86 \\
1.56\end{array}$ & $\begin{array}{l}1.45 \\
1.45 \\
1.62 \\
1.48 \\
1.56\end{array}$ & $\begin{array}{l}74 \\
74 \\
64 \\
72 \\
67\end{array}$ & & & & & & & $\begin{array}{l}2.94^{\mathrm{d}} \\
2.91^{\mathrm{d}} \\
3.37 \mathrm{~d} \\
3.85^{\mathrm{d}} \\
2.87^{\mathrm{d}}\end{array}$ & $\begin{array}{l}\text { Brown siltstone } \\
\text { Gray siltstone } \\
\text { Gray siltstone } \\
\text { Gray siltstone } \\
\text { Red siltstone }\end{array}$ \\
\hline $\begin{array}{l}23-1,72-73 \\
23-3,70-71 \\
23-3,145-146 \\
24-2,24-25 \\
24-2,137-138\end{array}$ & $\begin{array}{l}469.6 \\
472.6 \\
473.3 \\
498.1 \\
499.3\end{array}$ & $\begin{array}{l}2.25 \\
3.00 \\
3.34 \\
3.00 \\
3.16\end{array}$ & 2.76 & $\begin{array}{l}1.90 \\
1.90 \\
2.08 \\
2.24\end{array}$ & & $\begin{array}{l}1.62 \\
1.62\end{array}$ & $\begin{array}{l}64 \\
64\end{array}$ & & & & & & & $\begin{array}{l}5.24^{\mathrm{d}} \\
6.35^{\mathrm{d}} \\
6.24^{\mathrm{d}} \\
7.08^{\mathrm{d}}\end{array}$ & $\begin{array}{l}\text { Gray siltstone } \\
\text { Gray sandstone } \\
\text { Cemented breccia } \\
\text { Cemented breccia } \\
\text { Cemented breccia }\end{array}$ \\
\hline $\begin{array}{l}25-1,145-146 \\
25-2,145-146 \\
25, \text { CC }\end{array}$ & $\begin{array}{l}517.9 \\
519.4 \\
(519.6)\end{array}$ & $\begin{array}{l}3.40 \\
4.50 \\
3.75\end{array}$ & $\begin{array}{l}3.24 \\
4.15 \\
3.90\end{array}$ & $\begin{array}{l}2.22 \\
2.45\end{array}$ & & & & & & & & & & $\begin{array}{r}7.19^{d} \\
10.17 d\end{array}$ & $\begin{array}{l}\text { Cemented breccia } \\
\text { Cemented breccia } \\
\text { Cemented breccia }\end{array}$ \\
\hline
\end{tabular}

${ }^{a}$ Routine GRAPE values are averages for entire core section, normally based on eight measurements between 10 and $140 \mathrm{~cm}$ in section. A complete listing of routine GRAPE data is given in the Appendix.

$\mathrm{b}_{\text {Assumed grain density }}=2.65 \mathrm{~g} / \mathrm{cm}^{3}$

${ }^{\mathrm{c}}$ Conductivity data not processed. Sample locations indicated by $\mathrm{X}$.

${ }^{d}$ Determined using GRAPE density ( 2 min. count preferred, otherwise section average).

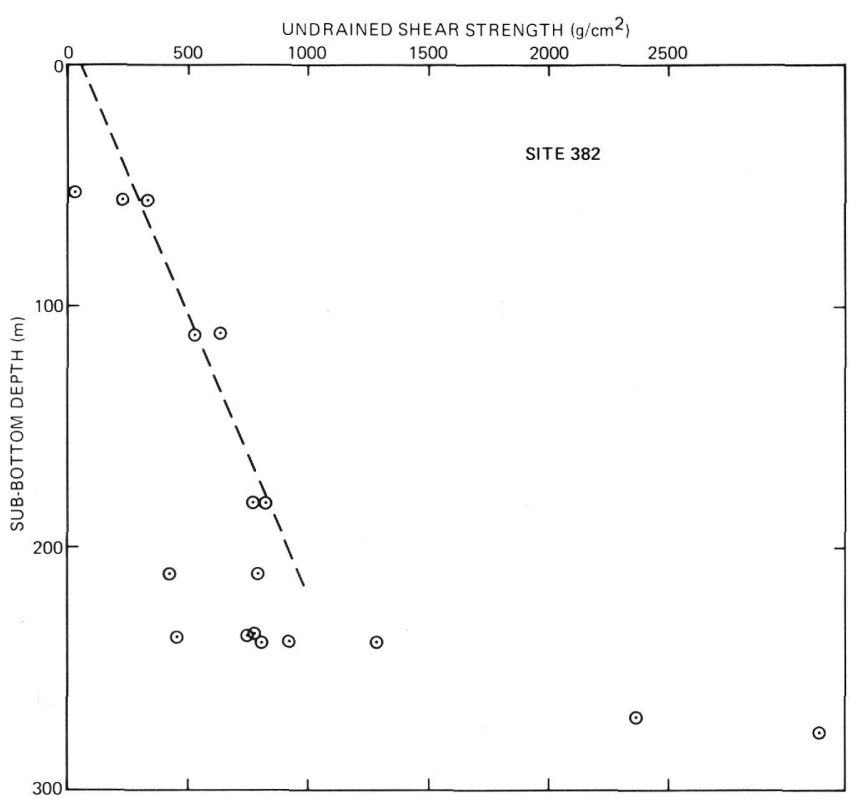

Figure 10. Shear-strength data for Site 382.

claystones have velocities of about $2.0 \mathrm{~km} / \mathrm{sec}$. The relatively large acoustic impedances of the two breccia layers suggest that they are strong acoustic reflectors.

\section{BIOSTRATIGRAPHY}

\section{Cenozoic Foraminifers}

Planktonic foraminifers are in general not well represented in the turbidites and hemipelagic clays cored at Site 382. They were found in the terrigenous silty and sandy clays of the upper abyssal plain sequence, and in isolated thin foraminifer-rich laminae or lenses in otherwise barren gray-green hemipelagic clays deeper in the hole. All foraminifer assemblages examined date from the upper Miocene to Pleistocene. Solution effects range from nil in part of the Pleistocene to extensive in the Pliocene, to complete removal of carbonate in the lower Miocene radiolarian-bearing clays.

Pleistocene assemblages dominated by high-latitude species characterize Core 3, where Neogloboquadrina pachyderma is dominant. Globorotalia menardii, Pulleniatina obliquiloculata, and other low-latitude forms also were seen in Core 1 assemblages, but their presence here, in otherwise glacial faunas, probably results from downhole contamination or mechanical mixing inasmuch as glacial and interglacial faunas of the Atlantic are normally more or less mutually exclusive. The dominance of cool water (glacial) assemblages in Cores 1 through 4 suggests that the turbidite sequence was deposited mainly during glacial times. Because the turbidite sequence was discontinuously cored, and because interglacial sediments, if present, would be relatively thin, it was not possible to assign the Pleistocene assemblages to the glacialinterglacial zonation of Ericson et al. (1961).

Mid-Pliocene assemblages occur in two foraminiferbearing lenses in Core 5 (Section 1, 148-150 cm, and Section 2, 17-19 cm). The lower one is well preserved while the upper one shows signs of extensive solution. Nonetheless, both contain species diagnostic of the midPliocene (Globorotalia margaritae, Globoquadrina altispira, and right-coiling Pullenatina primalis), suggesting an age of about 3.3 to 3.8 m.y. Other species present include, among others, Neogloboquadrina atlantica, Sphaeroidinella dehiscens, and Globorotalia limbata. In addition, Sample 5-2, 17-19 cm contains redeposited Globotruncana spp., indicating some downslope transport of Cretaceous material.

A foraminifer-bearing lens in Core 7, Section 1, $54-57 \mathrm{~cm}$ yielded solution-impoverished upper Miocene fauna. Preservation is poor, but the assemblage includes Globigerinoides obliquus, Neogloboquadrina acostaensis, Globigerina nepenthes, Globoquadrina altispira, Globorotalia cf. G. miozea conoidea, and G. plesio- 


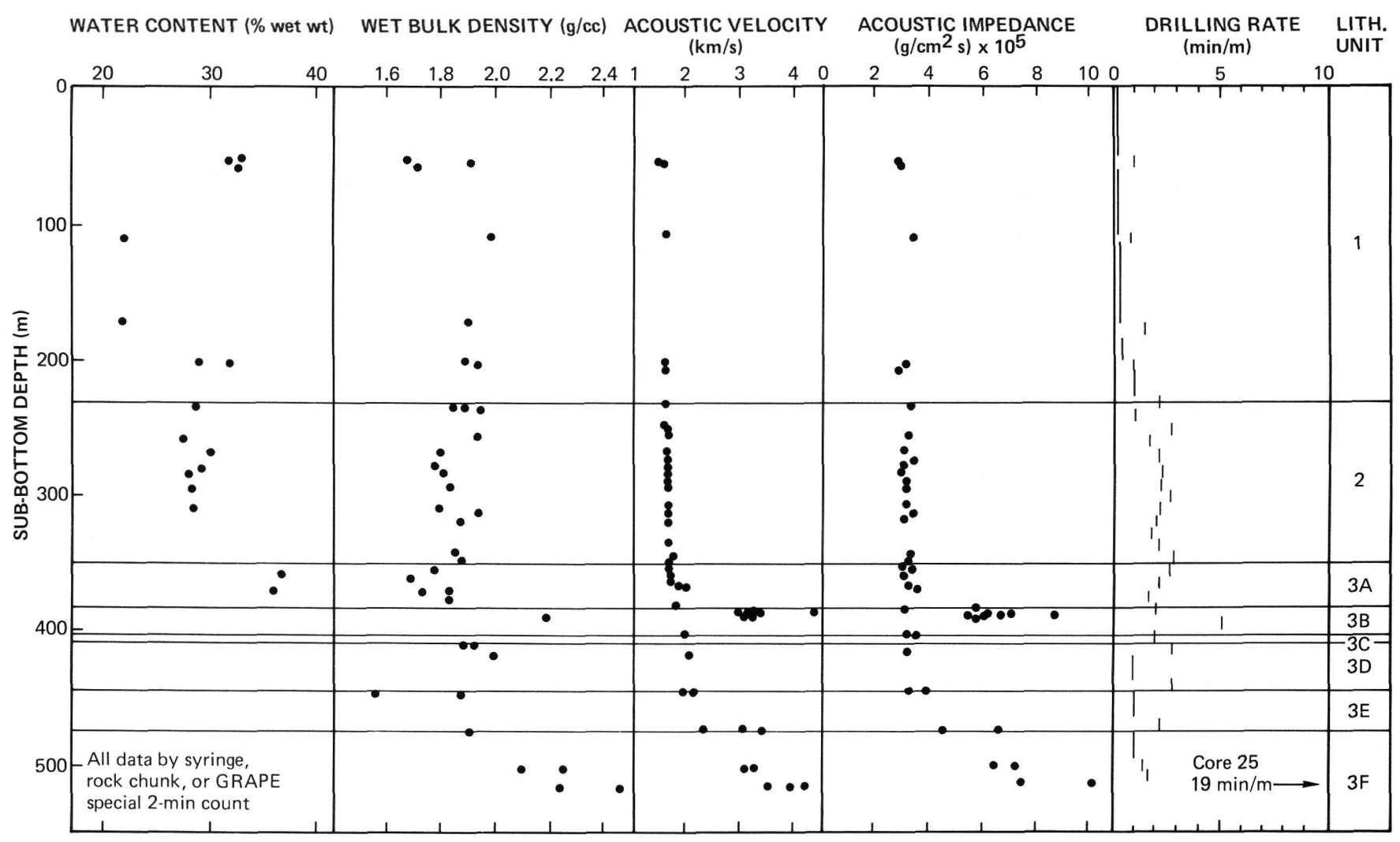

Figure 11. Physical properties data for Site 382.

tumida. This assemblage is indicative of the uppermost Miocene (Zone N.17 of Blow, 1969, and probably Messinian).

The remainder of the Cenozoic section at Site 382 appears to be barren of planktonic foraminifers, most probably because the site has been below the calcite compensation depth during the Neogene.

\section{Mesozoic Foraminifers}

Reworked Mesozoic forms occur sporadically in basal Tertiary clays. The first indigenous forms are found in Core 16. They occur in thin beds of chalk interbedded with barren clays that become dominant with depth. Specimens are uncommon and poorly preserved owing to dissolution, recrystallization, and overgrowth. They become exceedingly scarce below Core 17; only two samples from Core 18 and two from Core 19 yielded foraminifers, and they were rare and poorly preserved. Occasional, unidentifiable specimens occur in Core 20. No foraminifers were observed in Cores 21, 22, and 23.

Among the specimens recovered from residues, planktonics are dominant but the fauna is limited and is dominated by Globotruncana arca (Cushman), G. elevata (Brotzen), G. fornicata Plummer, G. lapparenti Brotzen, G. linneiana (d'Orbigny), and G. stuartiformis Dalbiez. In the absence of diagnostic upper Campanian or Maestrichtian forms, this assemblage is indicative of the Globotruncana elevata Zone (Cita and Gartner, 1971, p. 294-296), which is correlated with the lower Campanian.
Faunules from Core 16, Section 1, to Core 16, Section 4 , have a somewhat different aspect in their relative abundance of globigerinelloidinids and the possible presence of (?)Globotruncana hilli Pessagno and (?)Globigerinelloides subcarinatus Bronnimann, which appear in the upper Campanian. Unfortunately the specimens are rare, small, and poorly preserved, resulting in questionable identification. However, the nannofossils indicate lowermost upper Campanian for 16-1 to 16-4, and Globotruncana calcarata Cushman, an excellent upper Campanian marker known to be present in the area (Site 10, Leg 2; Cita and Gartner, 1971), may not appear at the lower-upper Campanian boundary. Consequently, the fauna of this interval could represent lowest upper Campanian.

\section{Nannofossils}

Nannoplankton of Quaternary to late Miocene and Campanian age were recovered at this site. Except for Core 1, where nannofossils are well preserved, preservation is moderately good to poor. Middle to upper Pleistocene assemblages (Gephyrocapsa oceanica Zone) occur in Cores 1 through 4. Almost all samples examined from these cores contain many reworked Cretaceous fossils whose relative count is more than 90 per cent of the total assemblage in some samples. Section 1 of Core 5 contains a flora of latest Pliocene age (Cyclococcolithus macintyrei Subzone) while Sections 2 and 3 yield assemblages of early late Pliocene (Discoaster tamalis Subzone). A short hiatus within the 
upper Pliocene is suspected. The interval from Core 5 , Section 4, through Core 6 is barren of calcareous nannoplankton. Within Cores 7 and 8, a few thin, light gray calcareous bands occur in otherwise unfossiliferous dark gray silt. Poorly preserved upper Miocene nannofossils (Discoaster quinqueramus Zone) are present in these samples. Cores 9 through 15 are barrern of calcareous nannoplankton.

The occurrence of Tetralithus aculeus in the upper half of Core 16 indicates the upper Campanian, while its absence below suggests lower Campanian for the sediments down to Core 23. Preservation deteriorates rapidly below Core 17 .

\section{Radiolarians}

Radiolarians were found in Cores 12,13 , and 14 of the hemipelagic clay section of Site 382 . A radiolarian specialist was not onboard ship for Leg 43, and the following are shore-based zonal determinations by $\mathbf{R}$. Goll. The radiolarian assemblages are lower Miocene: Core 12 belongs in the Stichocorys wolfii Zone, and Core 13 and Core 14 down to Section 3 belong in the Stichocorys delmontensis Zone. Section 5 of Core 14 also contains radiolarians but they are scarce and too poorly preserved for zonal determination. Cores 15,16 , and 17 were barren of radiolarians.

Radiolarians are also often common in the Cretaceous volcanogenic sequence, but here diagenetic effects, probably involving the replacement and/or encrustation of radiolarians by carbonate, render them unidentifiable.

\section{SEDIMENT ACCUMULATION RATES}

The observed trends in sediment accumulation rates at Site 382 (Figure 12) correlate reliably with rates expected from evaluation of the lithofacies.

Cenozoic sediments accumulated at two distinct rates: about $6 \mathrm{~m} / \mathrm{m} . \mathrm{y}$. on the average during the Miocene and $120 \mathrm{~m} / \mathrm{m} . \mathrm{y}$. during the Pleistocene. This contrast in accumulation rate corresponds with the lithologic break from Miocene and lower Pliocene hemipelagic clays to upper Pliocene and Pleistocene turbidites in Core 5. The high Pleistocene rate is reasonable for deposition of a distal turbidite sequence.

A major $45+$ m.y. hiatus occurs between the lower Miocene of Sample 14, CC and the upper Campanian of Core 16, Section 1. The hiatus corresponds to a marked lithologic change from greenish gray hemipelagic clays above to volcanogenic clays and breccias below. There are three possible explanations for the hiatus:

1) Accumulation rates were drastically reduced at the end of the Cretaceous, due largely to loss of volcanogenic sources and sea-floor subsidence below the CCD.

2) Reduction in or prevention of sediment accumulation by early Tertiary abyssal currents, or

3) Removal of an unknown volume of previously deposited material in the Paleogene by processes such as abyssal-current erosion or slumping.

The first explanation is considered unlikely because even the lowest accumulation rates observed in the modern oceans are an order of magnitude higher than would be required for this interval at Site 382 . The second possibility is also unlikely because significant bottom circulation in the western Atlantic basin was probably not initiated until at least late Paleocene or early Eocene time (Hollister, Ewing, et al., 1972; Jones et al., 1970; Berggren and Hollister, 1974).

The third alternative, however, is reasonable, both because of post-Paleocene abyssal circulation and because the slope $(\sim 1: 12)$ of the volcaniclastic apron is sufficiently steep to cause slumping. There are no primary sedimentary structures at or near the hiatus to suggest bottom-current activity, so that slumping seems a likely explanation. However, Paleogene hiatuses have been encountered at numerous sites in the western and eastern Atlantic. Few of these can be explained by slumping; hence, a more regional process such as current erosion may still be involved.

Average accumulation rates in the Campanian were high $(>30 \mathrm{~m} / \mathrm{m} . \mathrm{y}$.$) and probably quite variable on a$ fine scale. Lithofacies that suggest at least two primary volcanic episodes culminating in deposition of volcaniclastic breccia probably also suggest corresponding gross changes in accumulation rate.

\section{CORRELATION OF SEISMIC PROFILE WITH DRILLING RESULTS}

Four primary acoustic intervals are recognized in the Challenger seismic profiles near and across Site 382 (Figures 2, 4, and 13). Their acoustic character, from the topmost to the deepest unit, is described below.

Acoustic interval 1 is highly reflective, and shows strong, closely spaced acoustic laminae. The laminae are nearly horizontal, grading downward to weakly undulating in partial conformity to deeper structures. At Site 382 the interval is about 0.27 sec. thick (two-way reflection time), but it varies from zero to about $0.4 \mathrm{sec}$. in thickness within a hundred kilometers of the site.

Acoustic interval 2 is acoustically nonlaminated or very weakly laminated. Its upper contact with interval 1 is generally diffuse and sometimes irregular. Within 100 kilometers of Site 382 its thickness varies irregularly from zero up to about $0.5 \mathrm{sec}$, and it is about $0.17 \mathrm{sec}$. thick at Site 382.

Acoustic interval 3 has an upper surface which is smooth to gently undulating, creating a strong, reverberant echo. Interval 3 merges laterally with the "acoustic basement" of Nashville Seamount and slopes away from the seamount, forming a wedge-shaped apron. In most parts of the seamount apron the upper boundary of this interval constitutes the deepest observed reflector. The seamount represents the outcrop of this interval.

Beyond the apron comprising interval 3, irregular and mostly non-coherent echoes represent the surface of Layer 2 and acoustic interval 4, i.e., the top of normal oceanic crust. The surface of this interval mostly is masked where acoustic interval 3 is present, but it can be inferred locally where weak, incoherent and irregular echoes are observed below interval 3. At Site 382 this type of reflector appears approximately $0.57 \mathrm{sec}$. subbottom, near the level of the surrounding oceanic basement. However, both the Challenger and other profiles (Figures 2 and 4) suggest that the oceanic basement has 


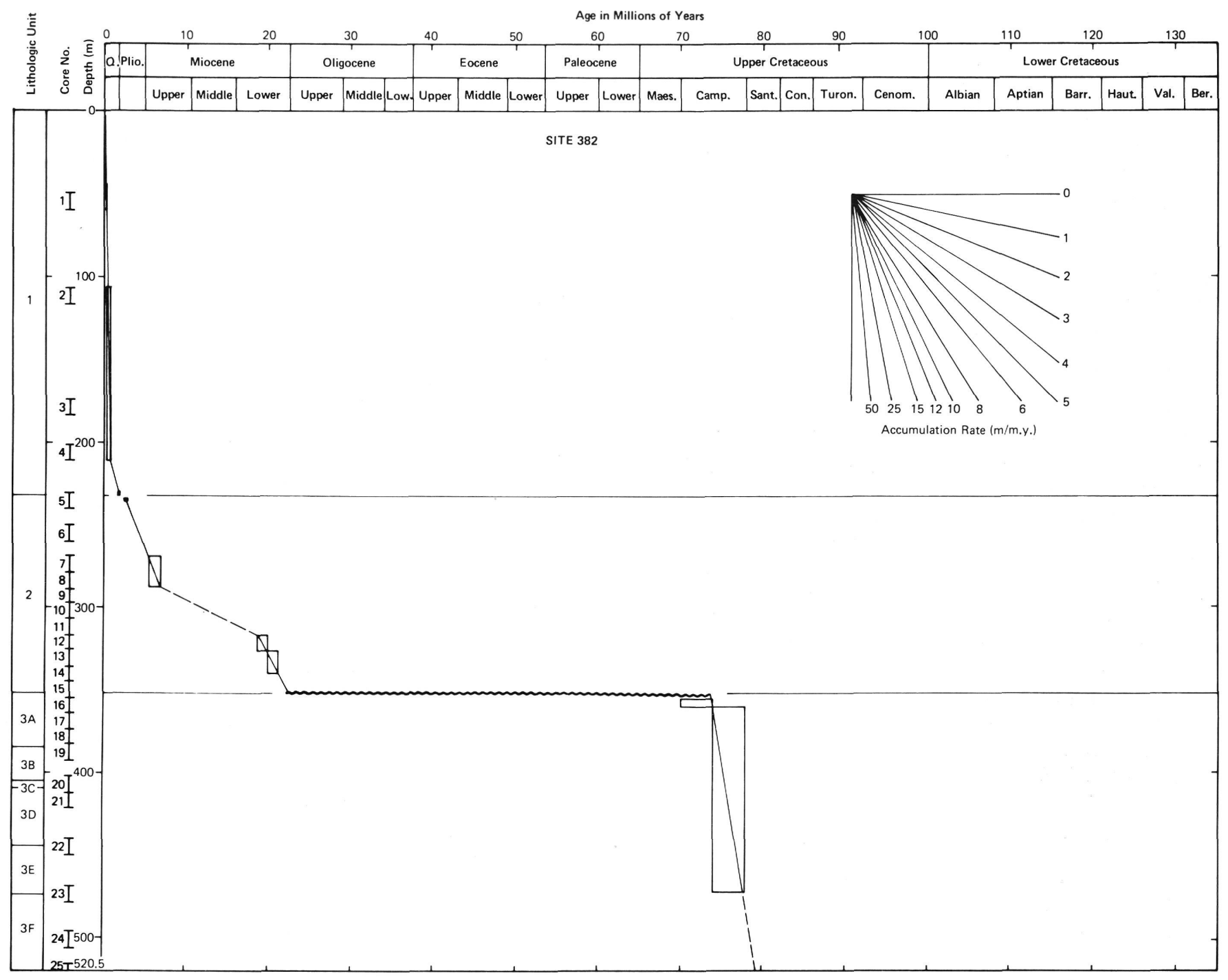

Figure 12. Sediment accumulation rates at Site 382.

been regionally deepened by several hundred meters near the seamount, probably in isostatic response of the plate to the load of volcanics. The relatively shallow depth of this reflector at Site $\mathbf{3 8 2}$ suggests that it may be either a local basement rise or a volcanogenic horizon created by seamount volcanism and postdating the formation of original crust.

The correlation of these acoustic intervals with lithofacies at Site 382 can be reasonably inferred (Figure 13). At the drill site, boundaries between the acoustic intervals in the Challenger record cannot be identified to a precision better than $\pm 0.01 \mathrm{sec}$.

Acoustic interval 1 correlates with distal Quaternary turbidites and interspersed hemipelagic clays cored from 0 to 232 meters sub-bottom (lithologic Unit 1). Although the apparent reflectivity of these sediments is relatively high, surprisingly little sand was cored from this unit, and no problems were encountered with hole stability. Acoustic lamination is less well developed at the base of this unit, possibly reflecting the early deposition of relatively finer-grained distal turbidites. However, this weak lamination may be explained equal- ly well by reduced impedance contrasts in the consolidated silts and clays in the more deeply buried section. The interval velocity calculated for the turbidites is about $1.72 \mathrm{~km} / \mathrm{sec}$ (Figure 14), which is comparable with sonobuoy-measured velocities for the upper few hundred meters of sediment in both the Sohm and Hatteras abyssal plains (R. Houtz, unpublished data).

Acoustic interval 2 correlates with Miocene-Pliocene hemipelagic clays and Campanian variegated clays at 232-385 meters (lithologic Units 2 and 3A), and it has a calculated interval velocity of about $1.80 \mathrm{~km} / \mathrm{sec}$. The upper, acoustically non-laminated part of this interval (Figure 13) can be traced beneath much of the Sohm Abyssal Plain and northeastern Bermuda Rise; as a unit it is largely conformable with the underlying basement topography. Because these clays are bounded below by a major disconformity at Site 382 , we cannot predict with any certainty the basal age of the section in adjacent parts of the basin. However, the apparent absence of the middle Eocene Horizon $A^{C}$ in the adjacent basin to the east, and the application of Site 382 sedimentation rates to this basin, suggest that the bulk of sediment 

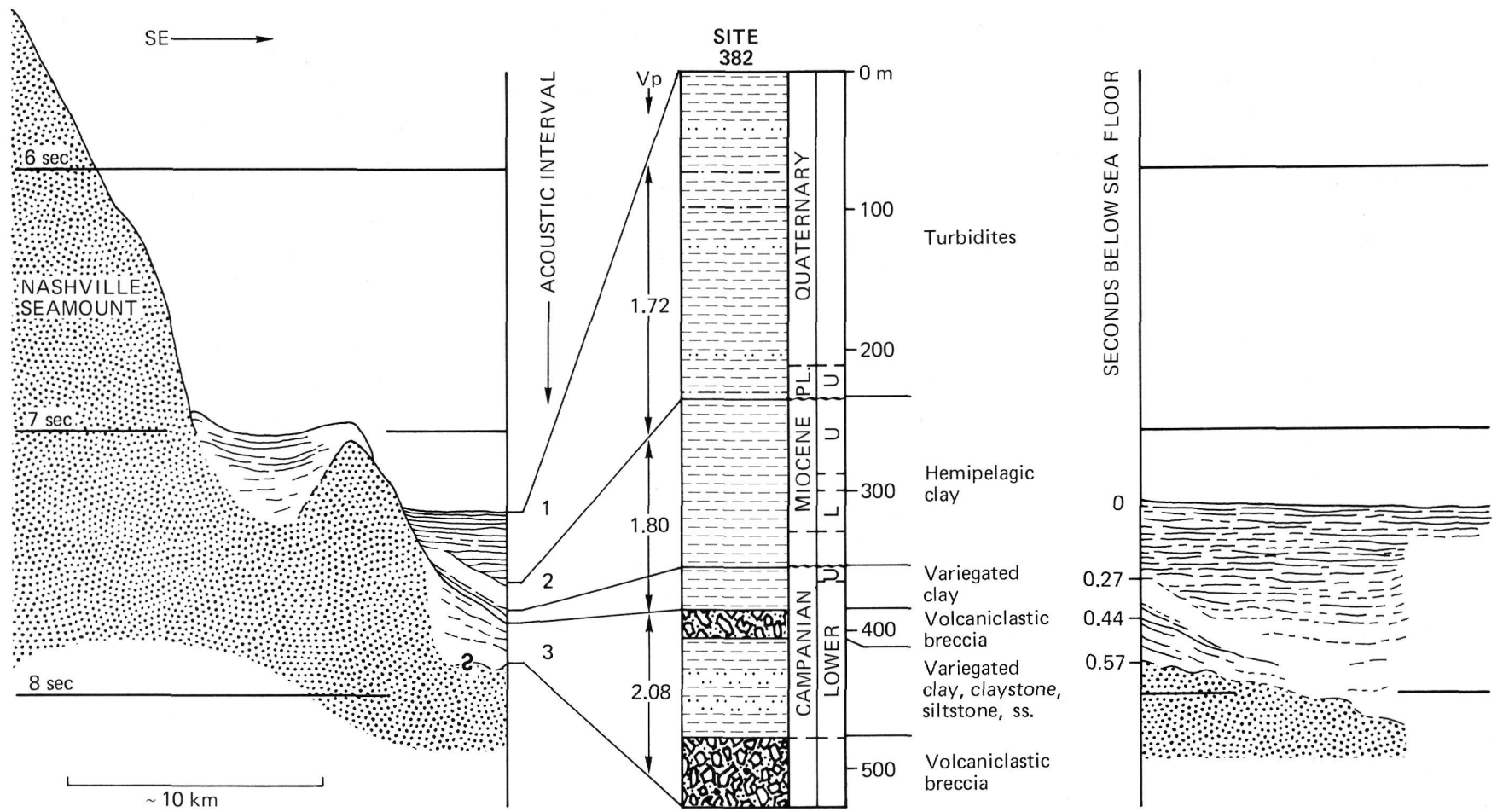

Figure 13. Correlation of lithologic record with seismic profile at Site 382.

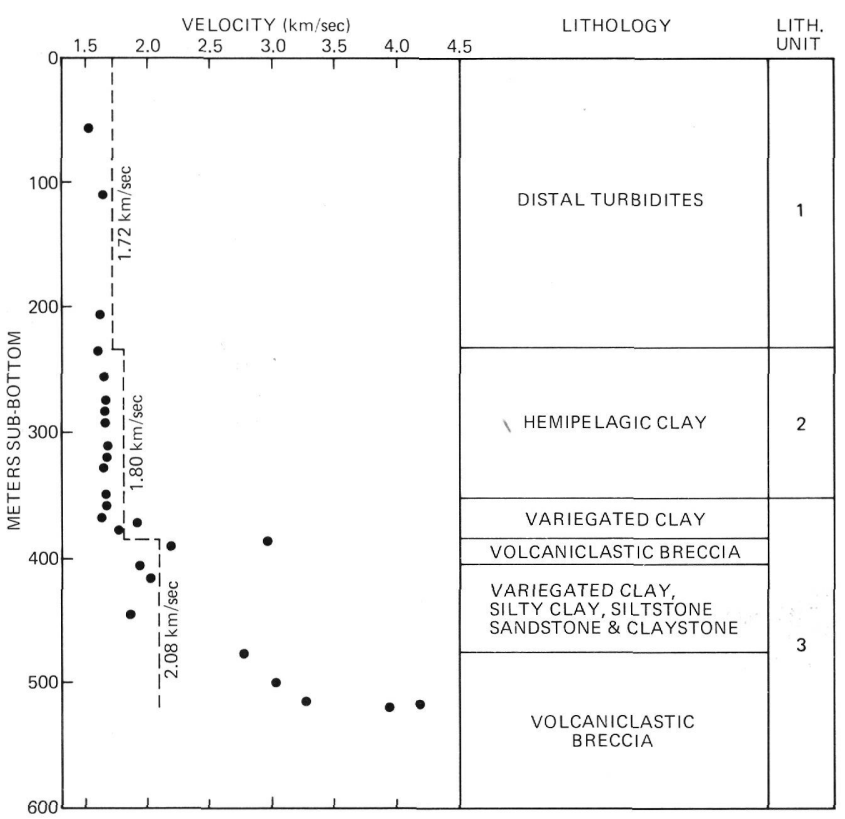

Figure 14. Sound velocities of samples directly measured in the Hamilton Frame velocimeter (dots) and interval velocities calculated from correlation between lithology and seismic record at Site 382 (dashed lines).

in the basin has been deposited in the late Paleogene and Neogene (post-Horizon $A^{C}$ ). This observation agrees with a similar conclusion (Ewing et al., 1970) based on study of seismic profiler data.

The lowermost part of acoustic interval 2 is interpreted to include the Campanian multicolored clays cored between 352 and 385 meters (lithologic Sub-unit
3A). Weak parallel laminae in the profiler record just above the interval 2-3 interface may correlate with these sediments, although acoustic impedance of the volcanogenic clays is only slightly higher than that of the overlying hemipelagic sediments.

Acoustic interval $3(0.44-0.57 \mathrm{sec})$ correlates with interbedded volcaniclastic breccias, sandstones, siltstones, and clays/claystones between 385 meters and about 520 meters (lithologic Sub-units 3B-3F). The sub-parallel acoustic laminae within this unit probably result from impedance contrasts between these lithofacies. The volcaniclastic breccia at the top of this section (385-404 m) provides the first strong acoustic interface observed in the drill hole (Figure 14), and it correlates well with the strong reflector at the top of acoustic interval 3.

We do not know whether the weak, irregular reflector observed at $0.57 \mathrm{sec}$. sub-bottom correlates with the high-velocity breccias recovered in Core 25 (516.5$520.5 \mathrm{~m}$ ). However, these breccias provide the only marked impedance contrast observed in the deep part of the drill hole (Figure 14), and they offer the most reasonable correlation with the acoustic record. Assuming this correlation is correct, the average in-situ interval velocity for the volcaniclastic section cored is $2.08 \mathrm{~km} / \mathrm{sec}$.

Velocities measured on sediment and hard rock samples with the Hamilton Frame velocimeter correlate well with the calculated interval velocities (Figure 14). In the mostly unconsolidated sediments of acoustic intervals 1 and 2, the calculated in situ velocities average about 8 per cent higher than the Hamilton Frame velocities. Similar discrepancies have been noted by Houtz (1975), based on detailed comparison with sonobuoy studies, for approximately the upper 300 meters of unconsolidated sediment in Leg 29 sites. The 
difference probably is due to coring disturbance and to differences between laboratory and in situ temperature and pressure. Hamilton Frame velocities in the third acoustic interval are a biased sample of high-velocity material, and no meaningful comparison can be made with calculated interval velocities.

\section{SUMMARY AND CONCLUSIONS}

\section{Introduction}

Site 382 was drilled $\mathbf{5 2 0 . 5}$ meters into sediment and the volcaniclastic apron on the eastern flank of Nashville Seamount, in 5527 meters of water (Figure 1). The upper 230 meters and the deepest 100 meters were discontinuously but regularly cored; the central section was nearly continuously cored and includes contacts between the acoustically laminated sediments of the Sohm Abyssal Plain and the underlying nonlaminated sediments that drape over oceanic crust throughout most of this part of the basin, and the contact with acoustic basement representing the volcaniclastic apron around Nashville Seamount. This apron was penetrated 136 meters before drilling was terminated. The principal objectives in drilling at this site were to date the cessation (and possibly the initiation) of volcanism at Nashville Seamount, to recover basaltic material for age dating and petrographic, geochemical, and magnetic studies, and to compare the timing of volcanic activity with that determined at seamount sites closer to the continental margin. According to the hot spot hypothesis (Morgan, 1973; Coney, 1971; Vogt, 1973), the ages of the New England seamounts should increase monotonically and more or less regularly from southeast to northwest. Nashville Seamount, then, would represent the youngest major volcano along the chain (the southeasternmost feature along the chain may be the relatively small Congress Seamount $200 \mathrm{~km}$ southeast of Nashville).

Secondary objectives of drilling included (a) dating the time at which significant turbidite accumulation began in this distal part of the Sohm Abyssal Plain, (b) determining the age and nature of the acoustcally nonlaminated sediments covering the basement topography in this area, and (c) investigating the possible northeastward extension of the Lower Cretaceous black clay facies and the Upper Cretaceous/(?)lower Tertiary multicolored clay facies drilled at earlier DSDP sites in the western North Atlantic.

Twenty-five cores were attempted, representing 45 per cent of the depth drilled, and 163.4 meters $(70 \%)$ of core were recovered. Most of the major objectives of this site were met, although time constraints precluded deep drilling to examine the time of initiation of volcanism at Nashville Seamount.

\section{Most Significant Results}

Core location, lithofacies, biostratigraphic zonation, sedimentation rates, and drilling rates are summarized in the graphic hole summary (Figure 5.) The upper Pliocene-Quaternary turbidites (Unit 1) were found to correlate with the acoustically laminated sedi- ments of the Sohm Abyssal Plain. Lower Miocene to Pliocene hemipelagic clays (Unit 2) underlie the turbidites and correlate with an acoustically nonlaminated interval of sediments that can be traced under the southern Sohm Abyssal Plain and the northeast Bermuda Rise. A major disconformity separates these sediments from those of the underlying Unit 3; this 50-m.y. hiatus may represent either localized slumping or extensive bottom current activity during Paleogene time. Volcanogenic sediments (Unit 3) form the acoustically opaque apron surrounding Nashville Seamount and are dated as lower Campanian (Core 16, Section 4, to Core 23, Section 2) and upper Campanian (Core 16, Sections 1-3). The entire thickness of the volcanogenic apron was not penetrated, so the earliest volcanism on Nashville may predate the early Campanian, although the volcano must have been virtually extinct by late Campanian time. We estimate that the seamount was constructed 85 to 80 m.y.B.P. The volcaniclastic breccias of the apron were apparently deposited as mass flows of volcanic debris from the crest and flanks of the seamount. Variations in the chemistry, vesicularity, and degree of alteration of basalt clasts suggest that the flows incorporated fragments from a variety of eruptive events. Carbonate values are locally high (up to 57\%) in the Campanian volcanogenic sediments just above the upper breccia; turbiditic textures of adjacent sediments suggest that at least some of the carbonates were derived from the crest and flanks of Nashville Seamount.

The volcaniclastic breccias appear to represent two episodes of volcanism on the seamount. The younger episode occurred in the early Campanian; the older may also date from the early Campanian or it may be older. The time between emplacement of the two breccias probably was a few million years or less. Volcaniclastic breccias between 473 and 520 meters subbottom (Sub-unit 3F) are overlain (from bottom to top) by variegated feldspathic silty claystone and clayey siltstone (3E), feldspathic silty claystone and clayey siltstone (3D), variegated silty clay (3C), volcaniclastic breccia with interbedded marly limestone (3B), and variegated clay, silty clay, and marly calcareous ooze (3A). Sub-units $3 \mathrm{~F}$ through $3 \mathrm{D}$ are interpreted as a sequence representing waning volcanism within the early Campanian. Sub-unit 3D, although feldspathic and zeolitic, does not have the color or textural aspects characterizing the altered ash in the variegated sub-units $(3 \mathrm{E}, 3 \mathrm{C}$, $3 \mathrm{~A}$ ), and it is thought to be composed primarily of hemipelagic material admixed with altered volcanic detritus that was reworked from the seamount during a time when the seamount was relatively inactive. Rejuvenation of volcanic activity later in the early Campanian is demonstrated by the variegated clays of Sub-unit 3C, culminating once again in deposition of volcaniclastic breccias (3B). The seamount probably was decreasingly active during the deposition of the latest (lower to upper Campanian) volcanogenic subunit (3A); these sediments contain an average of less than $10 \%$ of obvious volcanogenic detritus (zeolites, glass, palagonite), but their "altered ash"' appearance 
and varied colors suggest that a significant amount of fine volcanic detritus was still being derived from the seamount by winnowing and slumping of previously erupted material. Although it is difficult to estimate the original grain size of these sediments, they probably included substantial amounts of silt and finer detritus before alteration. While it is logical to assume a Nashville Seamount source for these materials, their assumed initial grain size does not preclude transport from a more distant source. Coarser interbeds were almost certainly derived from Nashville, probably by turbidity flows.

The volcaniclastic breccias are extremely valuable in interpreting the mechanisms of seamount development, and they are described in detail in the Lithologic Summary. Briefly, the breccias are composed of highly alkalic, vesicular basalt clasts in varying states of alteration, and they are cemented primarily by epidote, zeolites, and calcite. Their clast angularity, poor sorting, and occasional graded bedding suggest they were emplaced by slumping or debris flows from the crest and flank of the seamount. This is also suggested by the large variability in the degree of clast alteration, which demonstrates clast derivation from a variety of preexisting volcanic facies exposed to submarine alteration for varying lengths of time. Variable alteration can also be caused by differences in composition and vesicularity, but both of these parameters appear to be rather uniform in the breccia clasts. The assemblage of clasts was probably remobilized by volcanic/tectonic events during major eruptive phases. It seems unlikely that the radiometric ages of the basalt fragments (ranging from $79 \pm 4$ to $88.3 \pm 5.7$ m.y.B.P.; Houghton et al., this volume) represent a time significantly predating their deposition as breccias (see Vogt and Tucholke, this volume).

The vesicularity of the clasts in both breccias (3B, 3F) is commonly as high as 20 to 30 per cent. Such high vesicularity is usually restricted to basalt extruded at low confining pressures, specifically in water depths less than about 500 meters (Moore, 1965; Moore and Schilling, 1973). Rare Inoceramus prisms and unspecified shell fragments also occur in Sub-units $3 \mathrm{~A}$ and 3B, suggesting that the crest of the eastern peak of the seamount was in or near the photic zone near the time of the second eruption. However, there is no evidence for a flat, guyot-like top or reefal limestone on Nashville Seamount in either visual observations from the submersible ALVIN on the deeper peaks to the west (R. Houghton, personal communication; Figure 1) or in seismic reflection profiles.

Using these constraints we can make some further inferences about the development of this seamount in the context of what is known about crestal depths and subsequent deepening of ocean crust formed at the MidAtlantic Ridge. The crustal age at Site 382 is about 90 m.y. (Pitman and Talwani, 1972), and at the time of the earliest documented volcanism (early Campanian, or 77-80 m.y.; Sub-unit 3F) the sea floor would theoretically have been about 10-13 m.y. old, and thus about 3600-3800 meters deep (Sclater et al., 1971). On the basis of basalt vesicularity, the first of the two documented volcanic episodes constructed Nashville Seamount to within 500 to 1000 meters of sea level. The summit then apparently accumulated some shallow water mollusk remains which were shed downslope along with abundant volcaniclastics to form the volcaniclastic breccia of Sub-unit 3B during the second volcanic episode. A few million years at most elapsed between deposition of the two breccias; crustal subsidence during this interval could not have been significant. Minor unspecified shell debris in the subsequent volcanogenic clay unit (Sub-unit 3A) suggests that the seamount summit was still in the photic zone, but the lack of pumiceous sediments and the absence of a flat top on the seamount indicates the crest never actually reached sea level. Relatively rapid, isostatically determined sinking of the seamount was probably nearly concurrent with the volcanic buildup, that is, isostatic adjustment times of $10^{4}$ to $10^{5}$ years were probably negligible compared to the period of active volcanism. Subsequent slow sinking of the seamount crest caused by normal sea-floor subsidence brought it to the $2 \mathrm{~km}$ depth range presently observed. There are numerous uncertainties in this kind of interpretation (sea-floor age \pm 5 m.y.; depth of Cretaceous Mid-Atlantic Ridge crest, etc.), but several lines of independent reasoning suggest that this scenario is basically correct. The hypothesized 3600 to 3800 meter initial water depth is supported by the present 3600 -meter elevation of Nashville's crest above the nearby basement. This height would have elevated it into the photic zone, where we infer it was from lithology and petrography. Even without reference to the nearby basement we find the observed 2-km subsidence of the summit from the photic zone to be what the Sclater et al. (1971) curve predicts for the time interval 10 to 90 m.y. Finally, the height of Nashville Seamount above the surrounding basement is consistent with a crustal age of 10 to 13 m.y. at time of formation, on the basis of the relation between crustal age (i.e., plate thickness) and volcano height noted by Vogt (1974).

The question of the timing of volcanism at Nashville Seamount and along the New England seamount chain is addressed in detail by Vogt and Tucholke (this volume) and in the Site 385 Report.

\section{Disconformities in the Sedimentary Record}

A 50-m.y. hiatus was encountered between upper Campanian volcanogenic sediments and lower Miocene hemipelagic clays. The two most probable explanations for the absence of a sedimentary record in this interval are slumping and erosion by bottom currents.

The possibility of slumping is reasonable because the gradient of the volcaniclastic apron is about 1:12. However, the seismic records in this area show no features either within the apron or at its base that can be attributed to slumping, so any removal of material by this mechanism may have been minor. If slumping occurred, there is a possibility, admittedly unlikely, that post-Campanian volcanism occurred but its products were removed. 
Sediment non-deposition or even erosion by late Paleogene bottom currents also provides a possible explanation. Abyssal circulation after the late Eocene appears to have been strong enough to erode rather thick sedimentary sequences along the western margin of the basin (Hollister and Ewing, 1972; Tucholke and Vogt, this volume) and to redistribute the sediments as sediment drifts in areas of less intense circulation (Jones et al., 1970; Tucholke and Ewing, 1974). Although Nashville Seamount is more than $800 \mathrm{~km}$ from the present Western Boundary Undercurrent flowing along the western margin of the basin, it was close to the area of deep-water influx from the Labrador Basin in the Paleogene; this location plus probable flow intensification around the seamount locally may have eroded a substantial amount of pre-Miocene sediment and prevented much deposition until the Neogene. If bottom-current erosion explains the observed disconformity, there could not have been any deposition of volcaniclastic breccias post-dating the late Campanian, because bottom currents would have left a coarse lag deposit of breccia clasts.

Paleontologic and lithologic data also suggest a minor $(0.5$ m.y.) hiatus within the upper Pliocene at the contact between the turbidites of the Sohm Abyssal Plain and the underlying hemipelagic gray clays. It is not unreasonable to assume that erosion by the encroaching turbidity currents accounts for the small disconformity, or that slumping, possibly initiated by undercutting or bank-cutting by the turbidity flows, played a role. A third and possibly coincidental explanation is that bottom currents, intensified by increased production of bottom water during the onset of Arctic glaciation in the mid-Pliocene (Laughton, Berggren, et al., 1972), created an erosional disconformity.

\section{The Carbonate Record}

Carbonate values tend to be low $(10 \%)$ throughout the section drilled, except for numerous local calcareous oozes encountered in the Campanian section, where values can exceed 50 per cent. In Sub-unit 3A, upper Campanian oozes are enriched in fine-grained carbonate (foraminiferal remnants?) and nannofossils, and they are commonly burrowed. This information alone would suggest that Site 382 was close to the CCD and that carbonate concentration was controlled by minor fluctuations in this dissolution boundary or by dilution by volcanogenic components. However, the sharp contacts of the carbonate beds and the common occurrence of laminated and occasionally cross-laminated sediments in Sub-unit 3A suggest that part of the carbonate was emplaced from shallower areas on the crest and flanks of the seamount. High carbonate values are also encountered in marly limestones interbedded in the lower Campanian breccias of Sub-unit 3B. These beds show numerous laminae and cross laminae characteristics of turbidites, and they almost certainly were introduced to the site from higher on the seamount flank. The low carbonate values throughout the remaining part of the hole indicate that the sea floor probably was below the CCD throughout its recorded sedimentary history. The low carbonate content of even the oldest seamount sediments (lower Campanian) is rather surprising, since they are only 10 to $13 \mathrm{~m}$.y. younger than the crust itself. Apparently the early Campanian CCD was near or even above the 3600 to 3800 meter level from which Nashville Seamount began to grow, or biogenic calcite once present has been dissolved and perhaps reprecipitated as cement in the breccias.

\section{REFERENCES}

Bennett, R. H. and Keller, G. H., 1973. Physical properties evaluation. In van Andel, T. H., Heath, G. R., et al., Initial Reports of the Deep Sea Drilling Project, v. 16: Washington (U.S. Government Printing Office), p. 513-519.

Berger, W. H. and von Rad, U., 1972. Cretaceous and Cenozoic sediments from the Atlantic Ocean. In Hayes, D. E., Pimm, A. C., et al., Initial Reports of the Deep Sea Drilling Project, v. 14: Washington (U.S. Government Printing Office), p. 787-954.

Blow, W. H., 1969. Late middle Eocene to Recent planktonic foraminiferal biostratigraphy. In Brönnimann, P. and Renz, H. H. (Eds.), First Int. Conf. Plankt. Microfossils, Proceedings: Leiden (E. J. Brill), p. 199-421.

Boyce, R. E., 1974. DSDP procedures using the Gamma Ray Attenuation Porosity Evaluator (GRAPE). Instructions for grain density, wet-bulk density, water content and porosity determinations by individual samples and Gamma Ray Attenuation Porosity Evaluator. A DSDP Instruction Handbook (unpublished manuscript); La Jolla (Scripps Institution of Oceanography).

Cita, M. B. and Gartner, S., 1971. Deep sea Upper Cretaceous from the western North Atlantic, Second Int. Plankt. Conf., Proceedings: Leiden (E. J. Brill), p. 287-319.

Coney, P. J., 1971. Cordilleran tectonic transitions and motions of the North American plate, Nature, v. 223, p. $462-465$.

Drake, C. L., Ewing, J. I., and Stockard, H., 1968. The continental margin of the eastern United States, Canadian J. Earth Sci., 5, p. 993-1010.

Duncan, R. A. and McDougall, I., 1974. Migration of volcanism with time in the Marquesas Islands, French Polynesia, Earth Planet. Sci. Lett., v. 21, p. 414-420.

Dzulynski, S., Ksiazkiewicz, M., and Kuenen, P. H., 1959. Turbidites in flysch of the Polish Carpathian Mountains, Geol. Soc. Am. Bull., v. 70, p. 1089-1118.

Ericson, D. B., Ewing. M., Wollin, G., and Heezen, B. C., 1961. Atlantic deep-sea sediment cores, Geol. Soc. Am. Bull., v. 72, p. 193-286.

Ewing, J., Windisch, C., and Ewing, M., 1970. Correlation of Horizon A with JOIDES bore-hole results, J. Geophys. Res., v. 75, p. 5645-5653.

Ewing, M., Carpenter, G., Windisch, C., and Ewing, J., 1973. Sediment distribution in the oceans: The Atlantic, Geol. Soc. Am. Bull., v. 84, p. 71-88.

Garrison, L. E., 1970. Development of continental shelf south of New England, Am. Assoc. Petrol. Geol. Bull., v. 54, p. 90-124.

Heezen, B. C., Hollister, C. D., and Ruddiman, W. E., 1966. Shaping of the continental rise by deep geostrophic contour currents, Science, v. 152, p. 502-508.

Heirtzler, J. R., Ballard, R. D., Houghton, R. L., and Taylor, P. T., 1974. An investigation of the New England Seamounts by submersible, Trans. Am. Geophys. Union, v. 56, p. 1138 . 
Heirtzler, J. R., Ballard, R. D., Taylor, P., and Houghton, R. L., in press. Submersible observations of the New England Seamounts and Corner Rise, Am. Scientist.

Hollister, C. D., Ewing, J. I., et al., 1972. Initial Reports of the Deep Sea Drilling Project, v. 11: Washington (U.S. Government Printing Office).

Horn, D. R., Ewing, M., Horn, B. M., and Delach, M. N., 1971. Turbidities of the Hatteras and Sohm Abyssal Plains, Western North Atlantic, Mar. Geol., v. 11, p. 287-324.

Houghton, R. L. and Ballard, R. D., in preparation. Tectonic and petrologic observations of the New England Seamounts.

Houtz, R. E., 1975. Comparison of sonobuoy and sonic probe measurements with drilling results. In Kennett, J. P., Houtz, R. E., et al., Initial Reports of the Deep Sea Drilling Project, v. 29: Washington (U.S. Government Printing Office), p. 1123-1131.

Jackson, E. D., 1976. Linear volcanic chains on the Pacific plates. In Sutton, G. H., Manghnani, M. H., and Moberly, R. (Eds.), The Geophysics of the Pacific Ocean Basin and Its Margin: Am. Geophys. Union Monograph 19, p. 319-335.

Jones, E., Ewing, M., Ewing, J., and Eittreim, S., 1970. Influences of Norwegian Sea overflow water on sedimentation in the northern North Atlantic and Labrador Sea, $J$. Geophys. Res. v. 75, p. 1655-1690.

Keen, M. J., 1974. The continental margin of eastern North America, Florida to Newfoundland. In Nairn, A.E.M. and Stehli, F. G. (Eds.), The Ocean Basins and Margins, The North Atlantic: New York (Plenum Press), v. 2, p. 41-78.

Lancelot, Y., Hathaway, J. C., and Hollister, C. D., 1972. Lithology of sediments from the western North Atlantic, Leg 11, Deep Sea Drilling Project. In Hollister, C. D., Ewing, J. I., et al., Initial Reports of the Deep Sea Drilling Project, v. 11: Washington (U.S. Government Printing Office), p. 901-949.

Laughton, A. S., Berggren, W. A., et al., 1972. Initial Reports of the Deep Sea Drilling Project, v. 12: Washington (U.S. Government Printing Office).

Lee, H. J., 1973. Measurements and estimates of engineering and other physical properties. In Creager, J. S., Scholl, D. W., et al., Initial Reports of the Deep Sea Drilling Project, v. 19: Washington (U.S. Government Printing Office), p. 701-719.

Le Pichon, X. and Fox, P. J., 1971. Marginal offsets, fracture zones, and the early opening of the North Atlantic, $J$. Geophys. Res., v. 76, p. 6294-6308.

Moore, J. G., 1965. Properties of Hawaiian submarine basalt, Geol. Soc. Am. Spec. Paper 82, p. 267.

Moore, J. G. and Schilling, J. G., 1973. Vesicles, water, and sulfur in Reykjanes Ridge basalts, Contrib. Mineral. Petrol., v. 41, p. 105-118.

Morgan, W. J., 1973. Plate motions and deep mantle convection. In Shagam, R. (Ed.), Studies in Earth and Space Science: Geol. Soc. Am. Mem. 132, p. 7-22.
Pitman, W. C. and Talwani, M., 1972. Sea-floor spreading the North Atlantic, Geol. Soc. Am. Bull., v. 83, p. 619-646.

Rocker, K., 1974. Physical properties measurements and test procedures for Leg 27. In Veevers, J. J., Heirtzler, J. R., et al., Initial Reports of the Deep Sea Drilling Project, v. 27: Washington (U.S. Government Printing Office), p. 433-443.

Saito, K. and Ozima, M., 1976. $\mathrm{Ar}^{40} / \mathrm{AR}^{39}$ ages of submarine from the Line Islands: Implications on the origin of the Line Islands. In Sutton, G. H., et al. (Eds.), The Geophysics of the Pacific Ocean Basin and Its Margin: Am. Geophys. Mono. 19, p. 369-374.

Sayles, F. L. and Manheim, F. T., 1975. Interstitial solutions and diagenesis in deeply buried marine sediments: results from the Deep Sea Drilling Project, Geochim. Cosmochim. Acta, v. 36, p. 653-671.

Sbar, M. L. and Sykes, L. R., 1973. Contemporary compressive stress and seismicity in eastern North America, Geol. Soc. Amer. Bull., v. 34, p. 1861-1882.

Schilling, J. G., 1973. Iceland mantle plume: geochemical study of Reykjanes Ridge, Nature, v. 242, p. 565-571.

Sclater, J. G., Anderson, R. N., and Bell, M. L., 1971. Elevation of ridges and evolution of the central eastern Pacific, J. Geophys. Res., v. 76, p. 7888-7915.

Stevenson, F. J. and Cheng, C. N., 1972. Organic geochemistry of the Argentine Basin sediments: carbon-nitrogen relationships and Quaternary correlations, Geochim. Cosmochim. Acta, v. 36, p. 653-671.

Suppe, J., Powell, C., and Berry, R., 1975. Regional topography seismicity, Quaternary volcanism, and the presentday tectonics of the western United States, Amer. J. Sci., v. 275-A, p. 397-436.

Tucholke, B. and Ewing, J., 1974. Bathymetry and sediment geometry of the Greater Antilles Outer Ridge and vicinity, Geol. Soc. Am. Bull., v. 85, p. 1789-1802.

Uchupi, E., Phillips, J. D., and Prada, K. E., 1970. Origin and structure of the New England Seamount chain, DeepSea Res., v. 17, p. 483-494.

Vogt, P. R., 1973. Early events in the opening of the North Atlantic. In Tarling, D. H. and Runcorn, S. K. (Eds.), Implications of continental drift to the earth sciences: New York (Academic Press), p. 693-712.

1974. Volcano spacing, fractures, and thickness of the lithosphere, Earth Planet. Sci. Lett., v. 21, p. 235-352.

Vogt, P. R., Lorentzen, G. R., and Dennis, L. S., 1970. An aeromagnetic survey of the Keathley magnetic anomaly sequence between $34^{\circ} \mathrm{N}$ and $40^{\circ} \mathrm{N}$ in the western North Atlantic, Trans. Am. Geophys. Union, v. 51, p. 274.

Walczak, J. E., 1963. A marine magnetic survey of the New England Seamount chain, U.S. Naval Oceanographic Office Technical Report 159, p. 37. 

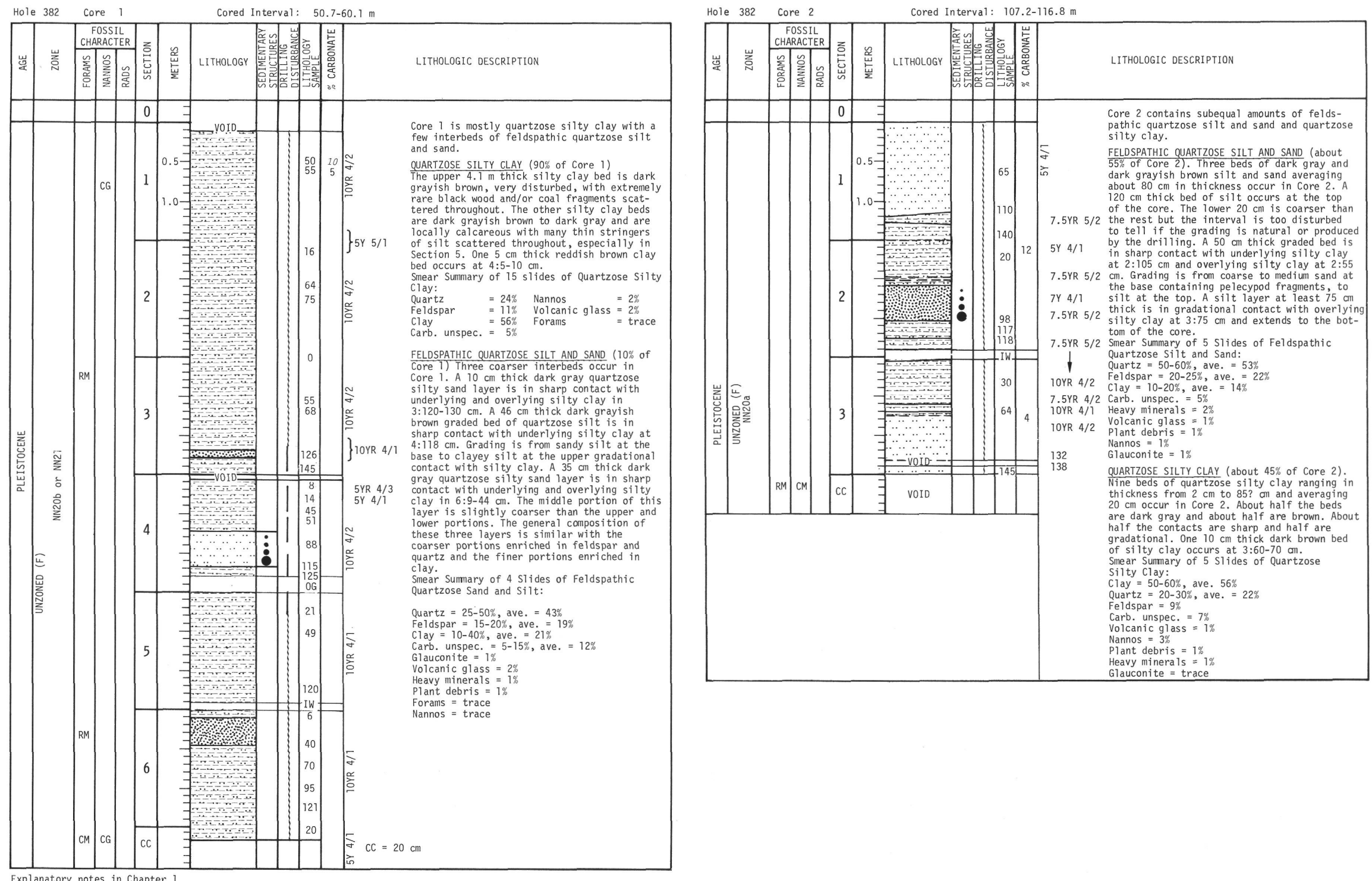

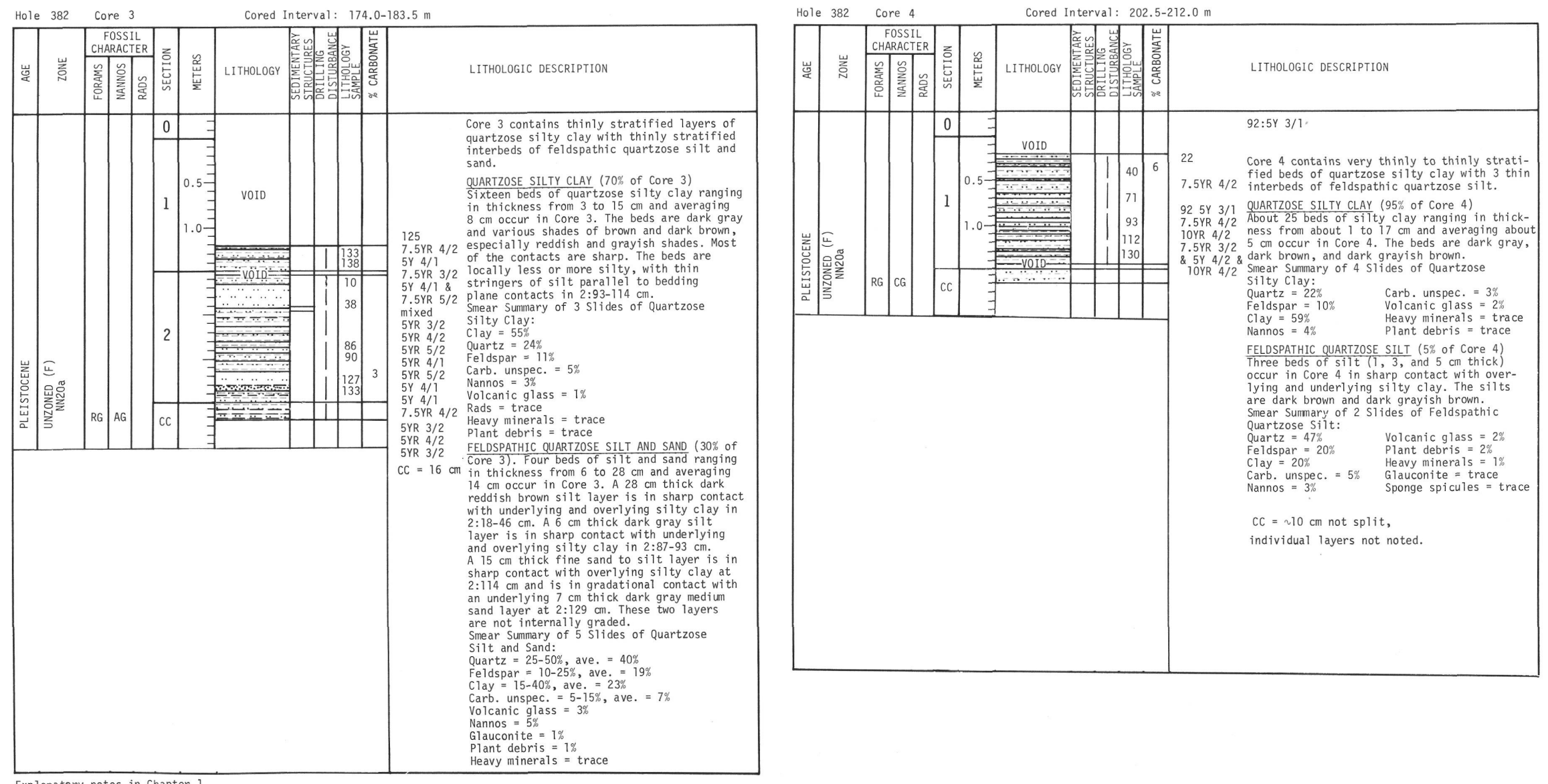

Explanatory notes in Chapter 1 

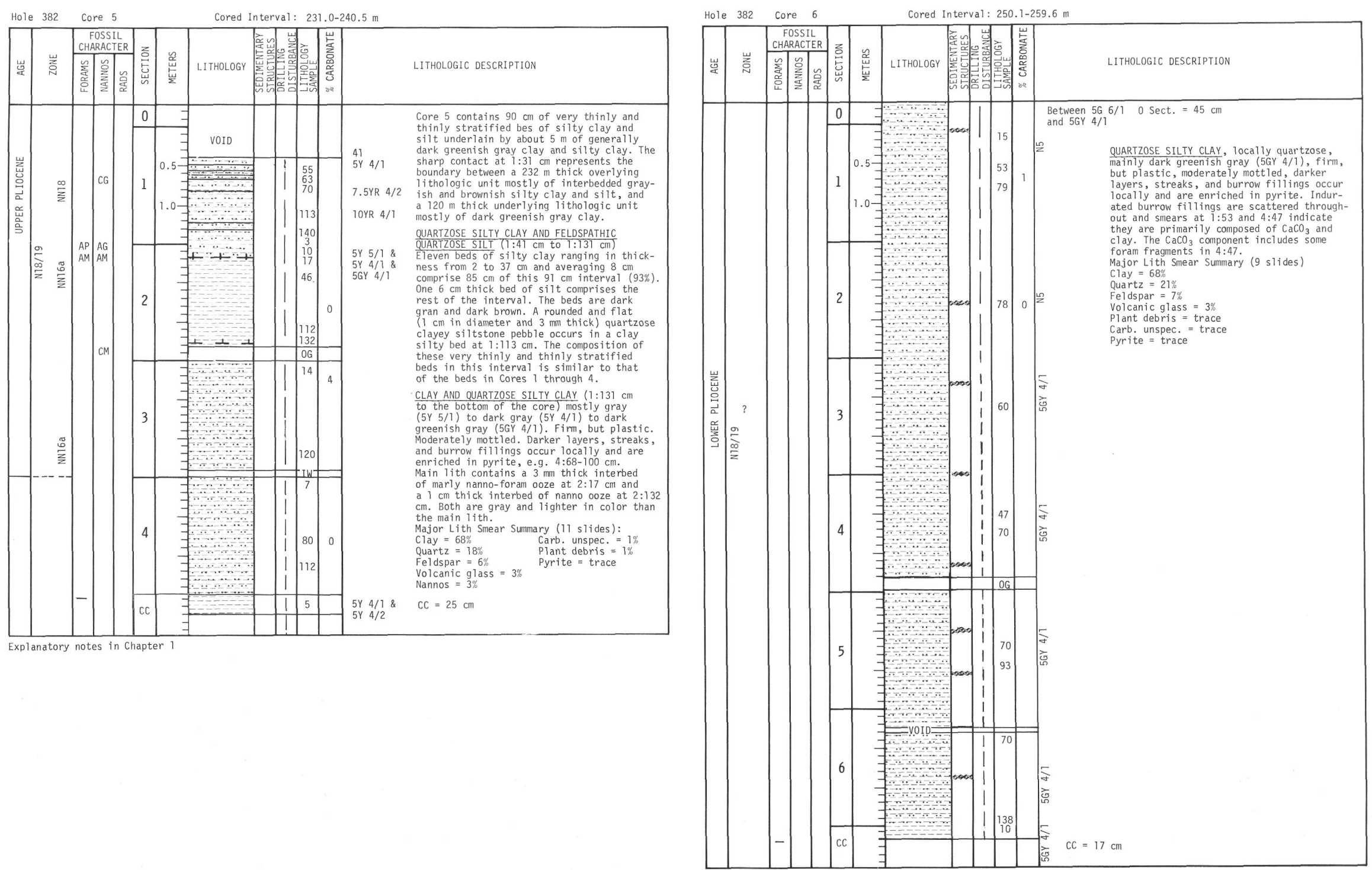

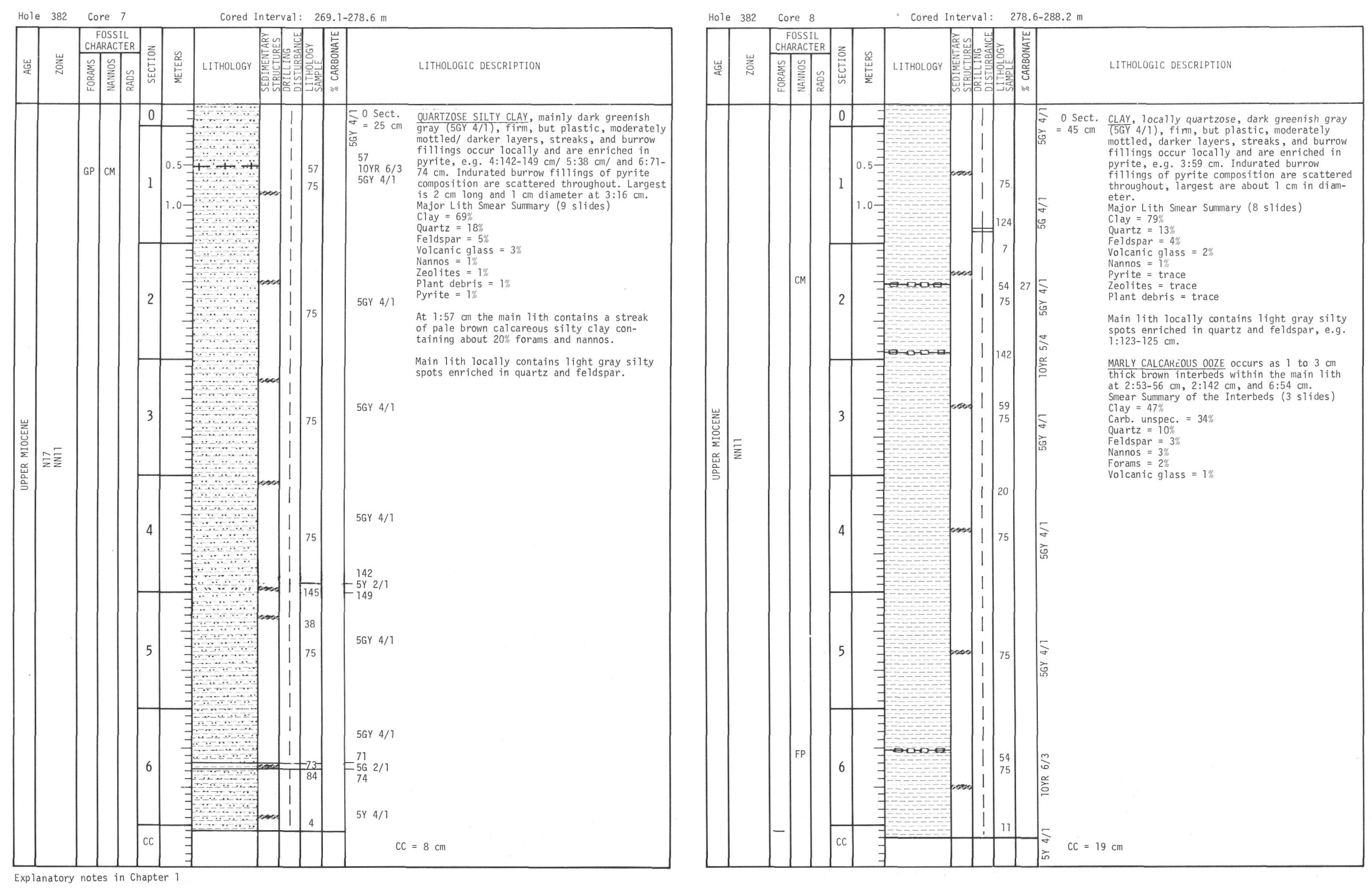


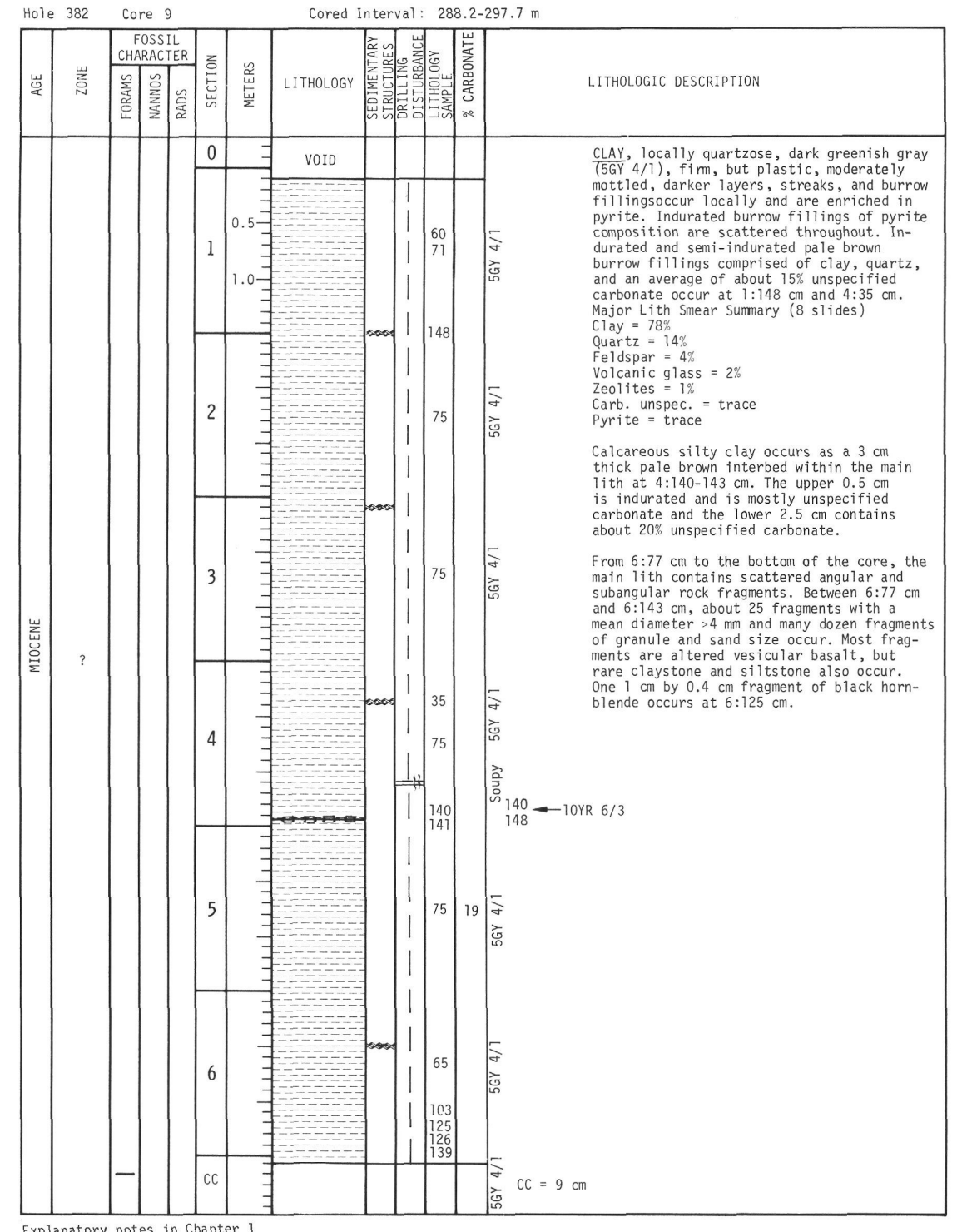

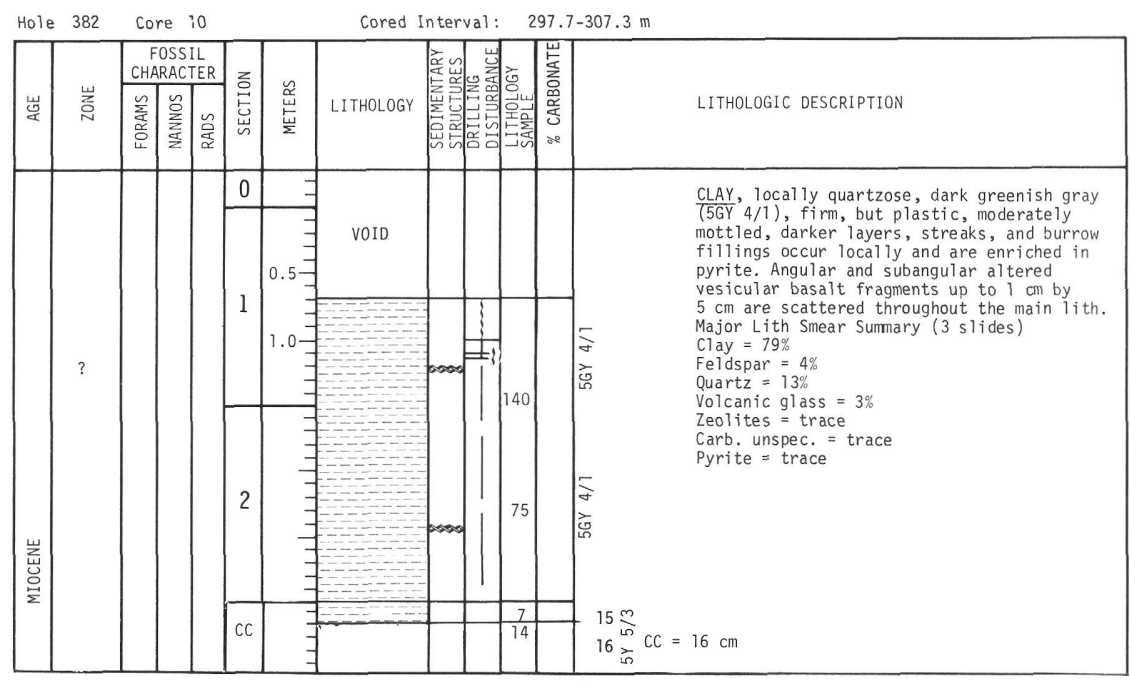



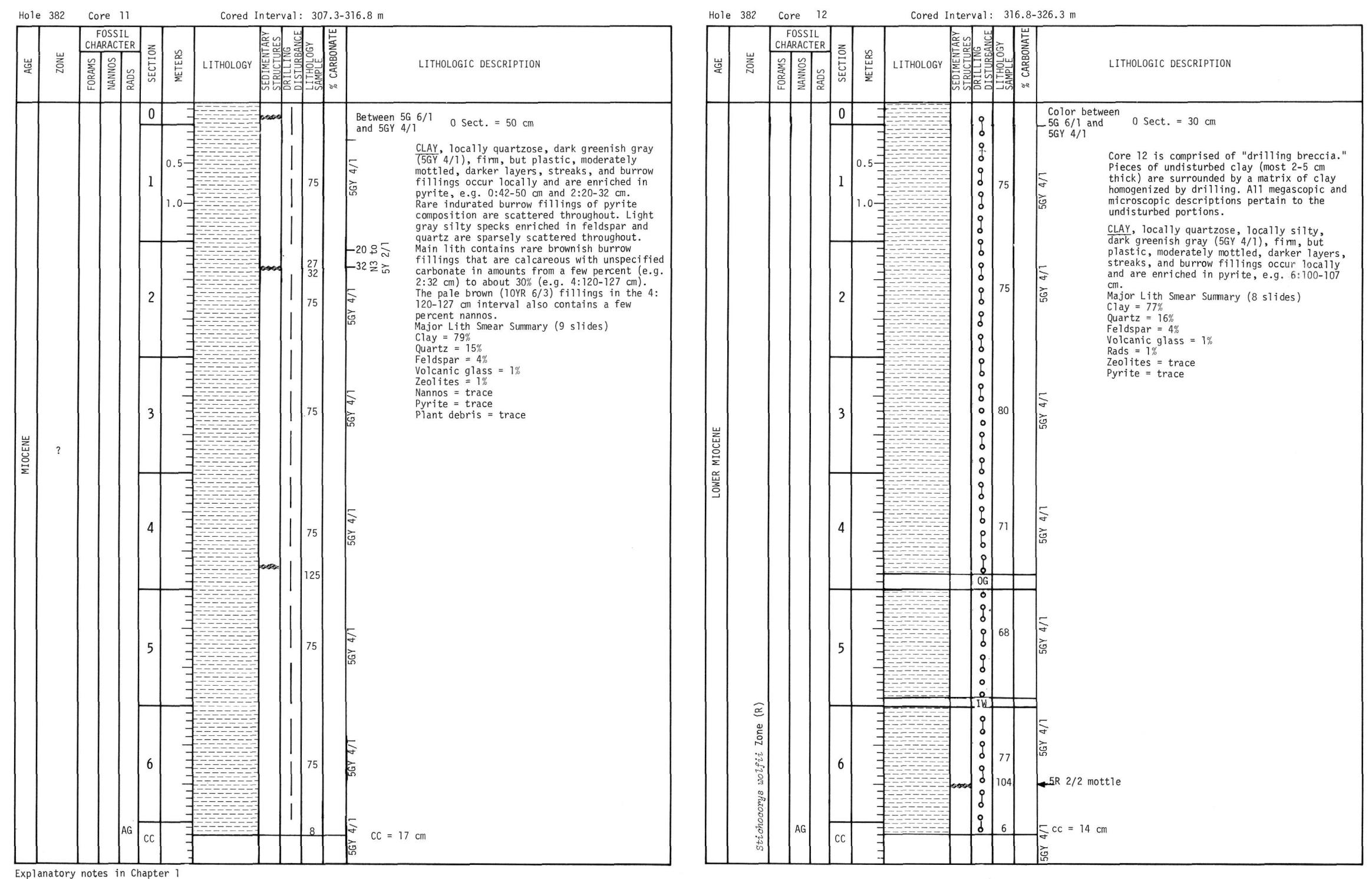

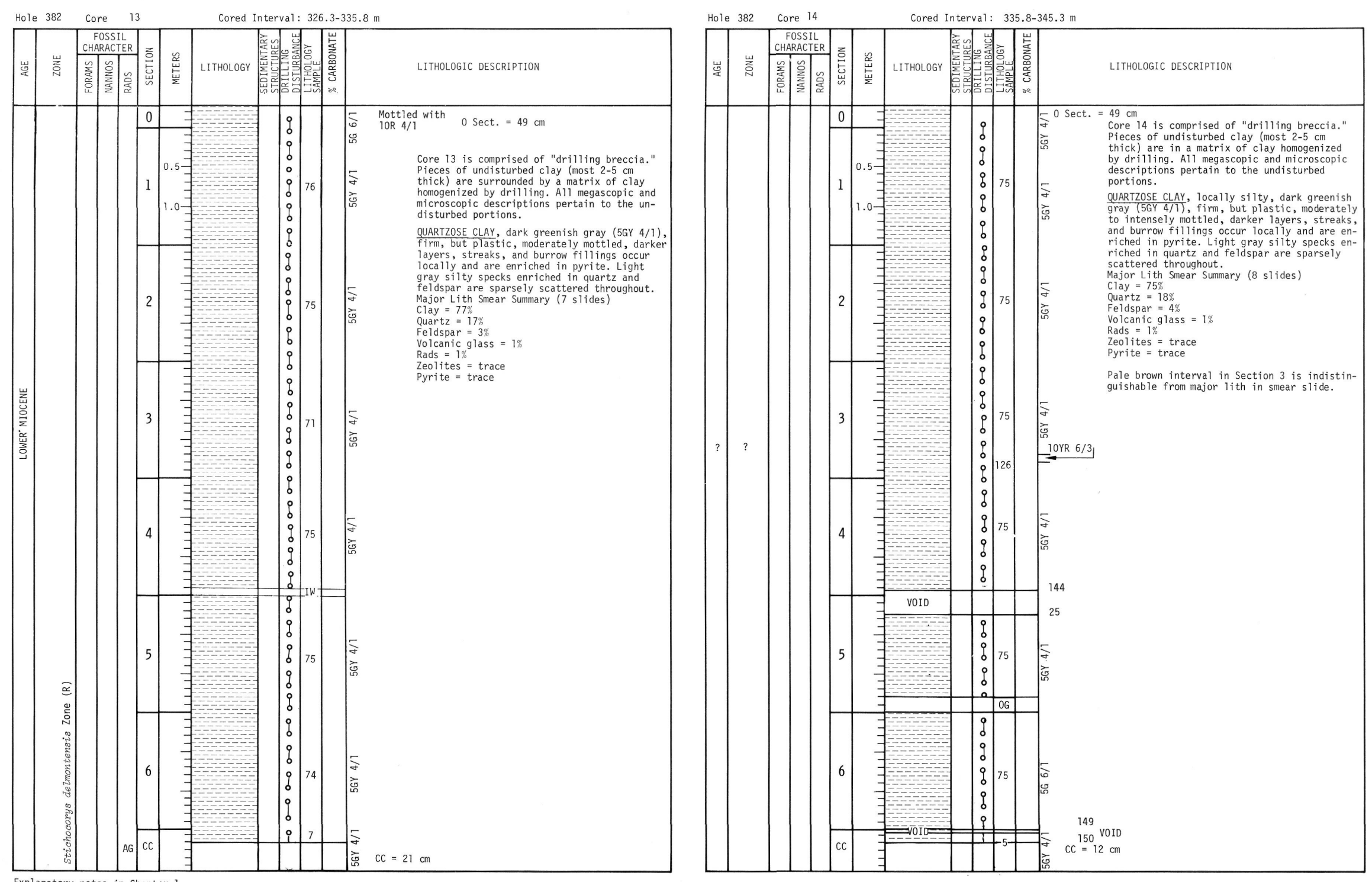


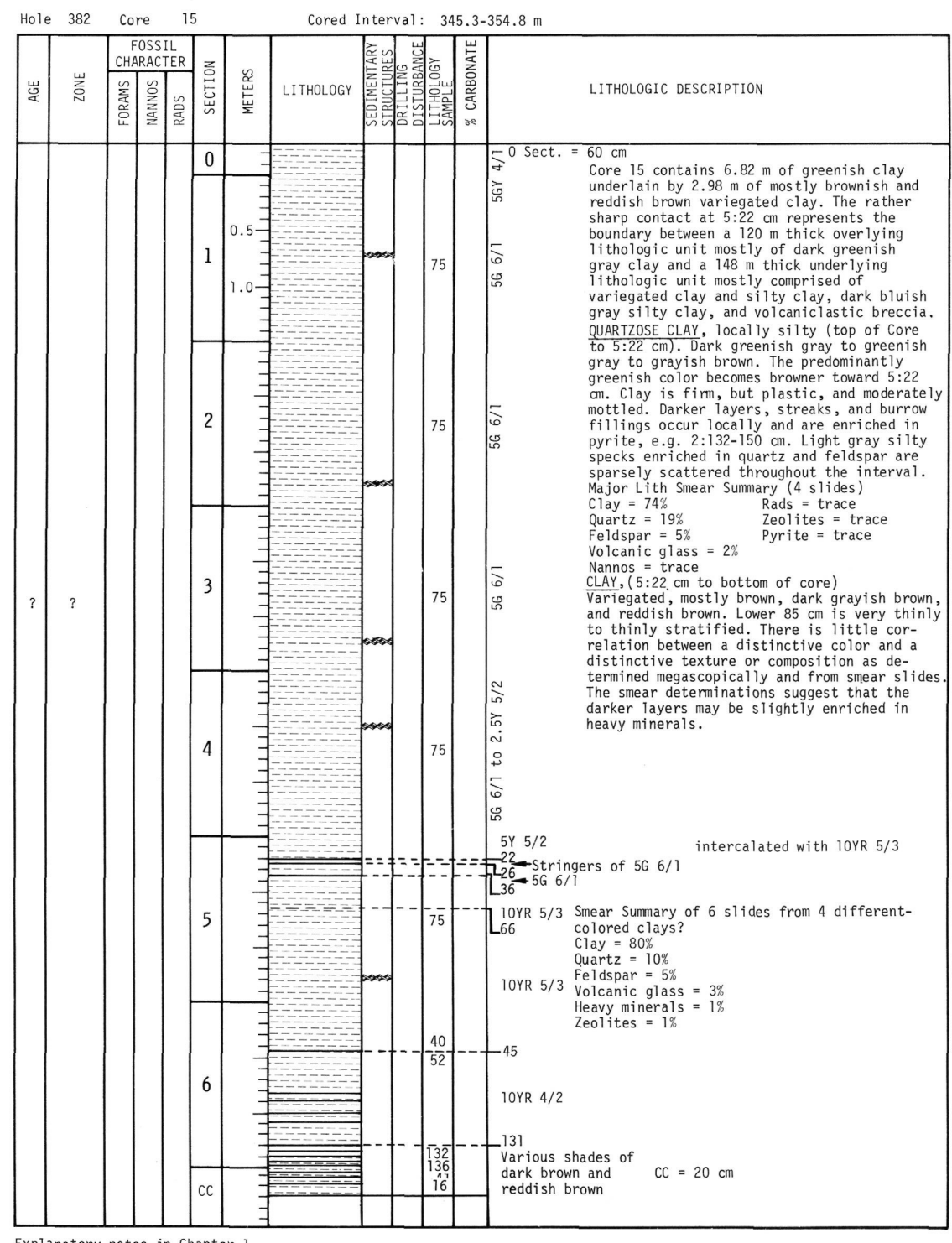

\begin{tabular}{|c|c|c|c|c|c|c|c|c|c|c|}
\hline 宸 & 谷 & 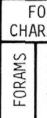 & 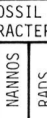 & 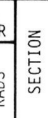 & 咅 & LITHOLOGY & 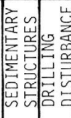 & & 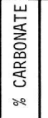 & LITHOLOGIC DESCRIPTION \\
\hline 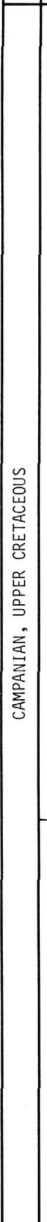 & 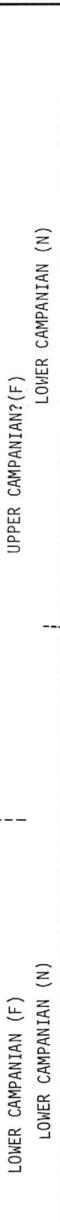 & $\begin{array}{l}\mathrm{CM} \\
\mathrm{AM}\end{array}$ & $\mathrm{AG}$ & 0 & $1.0=$ & 1 & 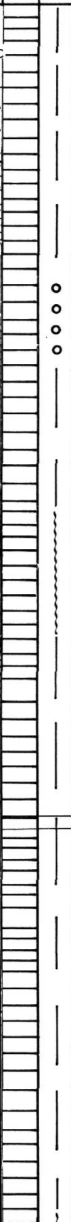 & \begin{tabular}{|c|}
77 \\
97 \\
112 \\
146 \\
147 \\
12 \\
47
\end{tabular} & 9 & 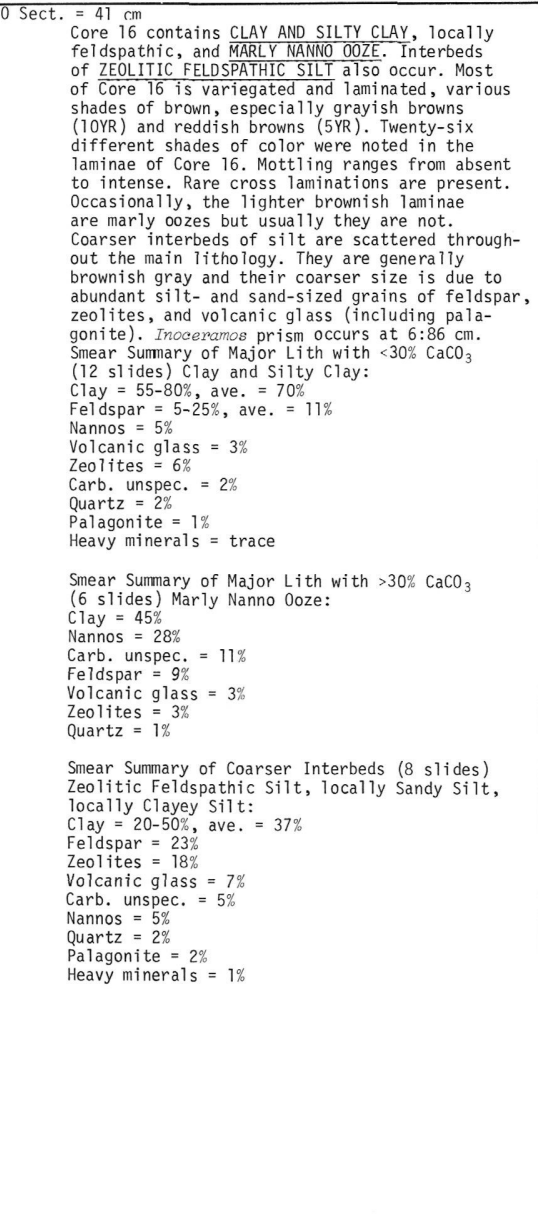 \\
\hline & & CM $A$ & AM & $\mathrm{cc}$ & & & & 2,9 & & $C C=15 \mathrm{~cm}$ \\
\hline
\end{tabular}


Cored Interval: $364.4-373.8 \mathrm{~m}$

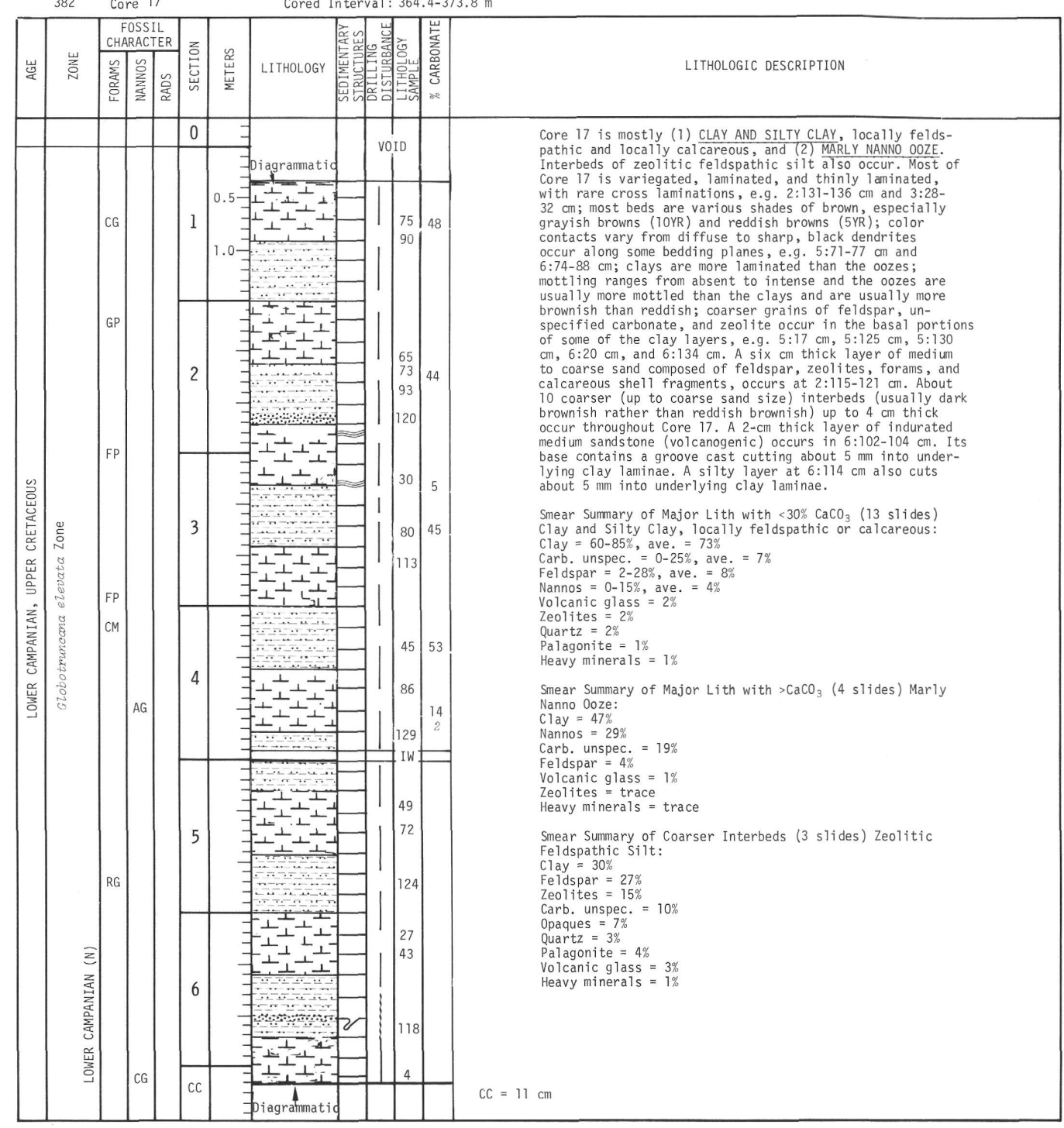

Explanatory notes in Chapter 1 


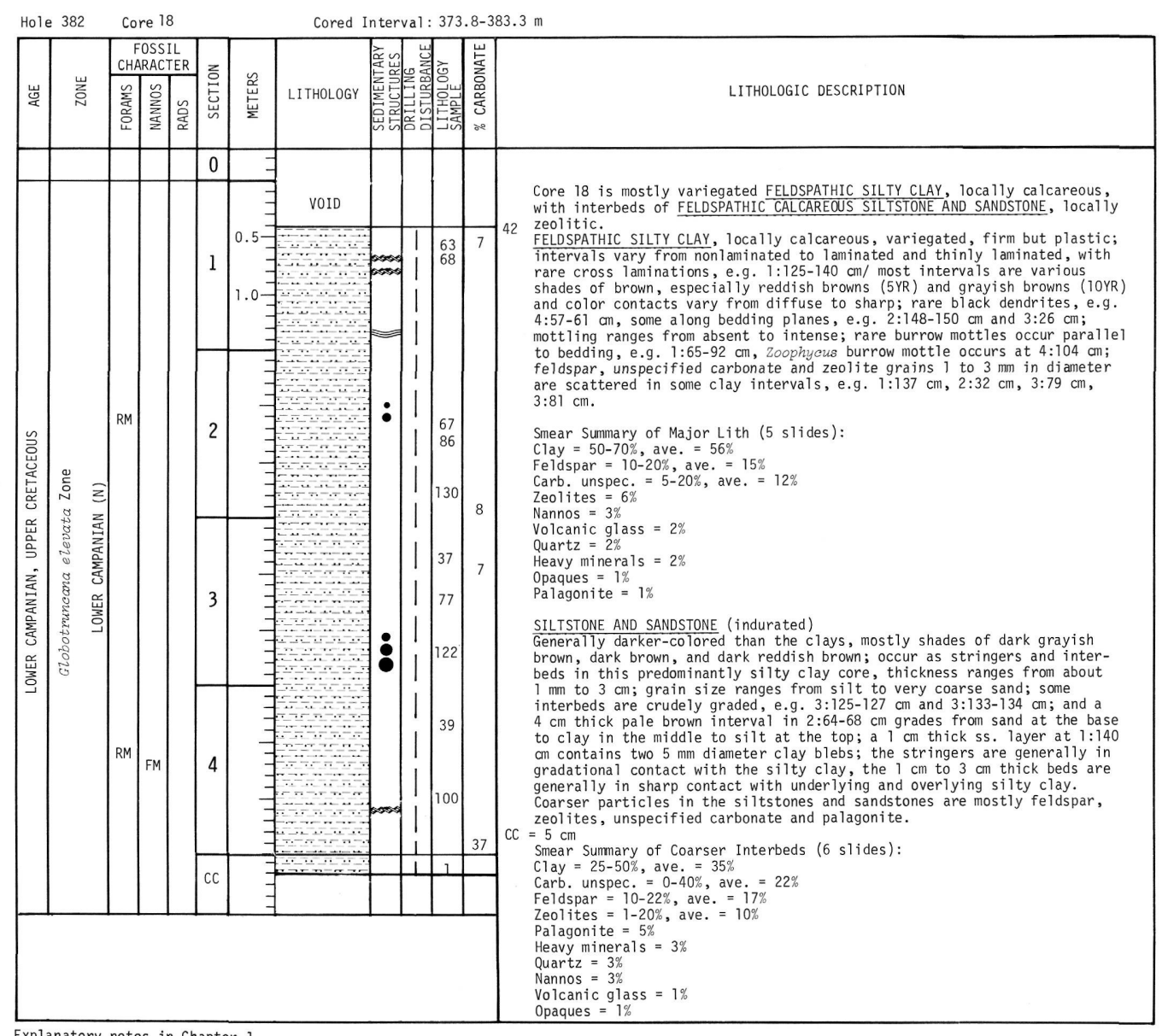




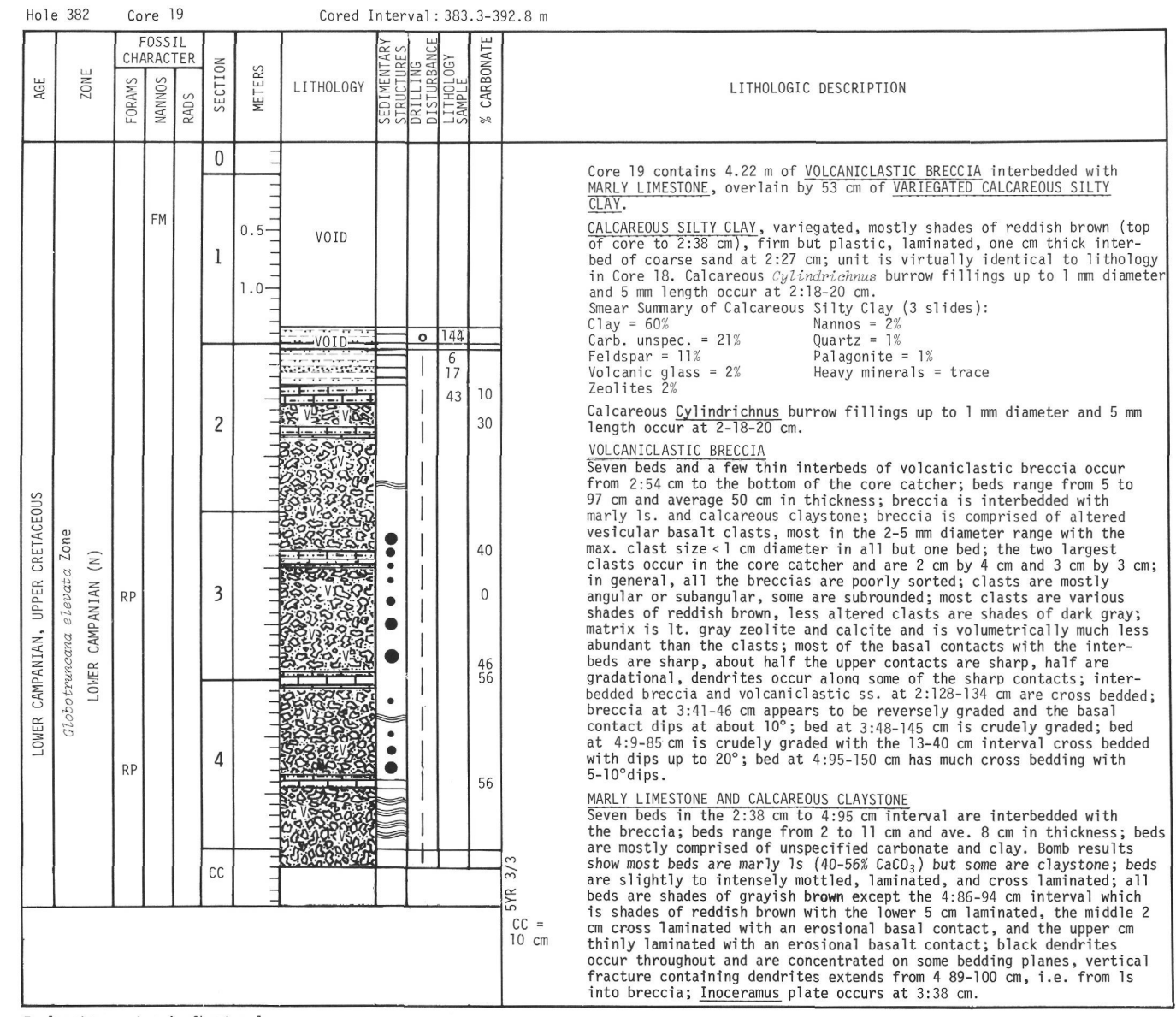

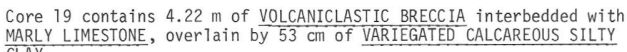

CALCAREOUS SILTY CLAY, variegated, mostly shades of reddish brown (top hed of coarse sand at $2.27 \mathrm{~cm}$. unit is virtually identical to 1 it thole (reous silty clay (3 slides):

Ouartz $=1 \%$

peavy minerals $=$ trace

alcareous cylindrichnus burrow fillings up to $1 \mathrm{~mm}$ diameter and $5 \mathrm{~mm}$ (a) is. and cat careous claystone; breccia is comprised of al tered

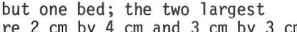
tacts with the interout half the upper contacts are sharp, half are

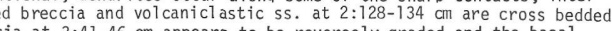

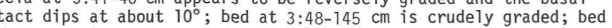
; bed at $4: 95-150 \mathrm{~cm}$ has much cross bedding with

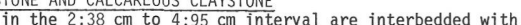
breccia; beds range from 2 to $11 \mathrm{~cm}$ and ave. $8 \mathrm{~cm}$ in thickness; beds $\begin{array}{ll} & \end{array}$ cross laminated with an erosional basal contact, and the upper $\mathrm{cm}$

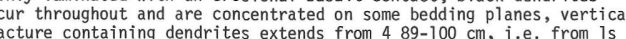

Explanatory notes in Chapter 1 


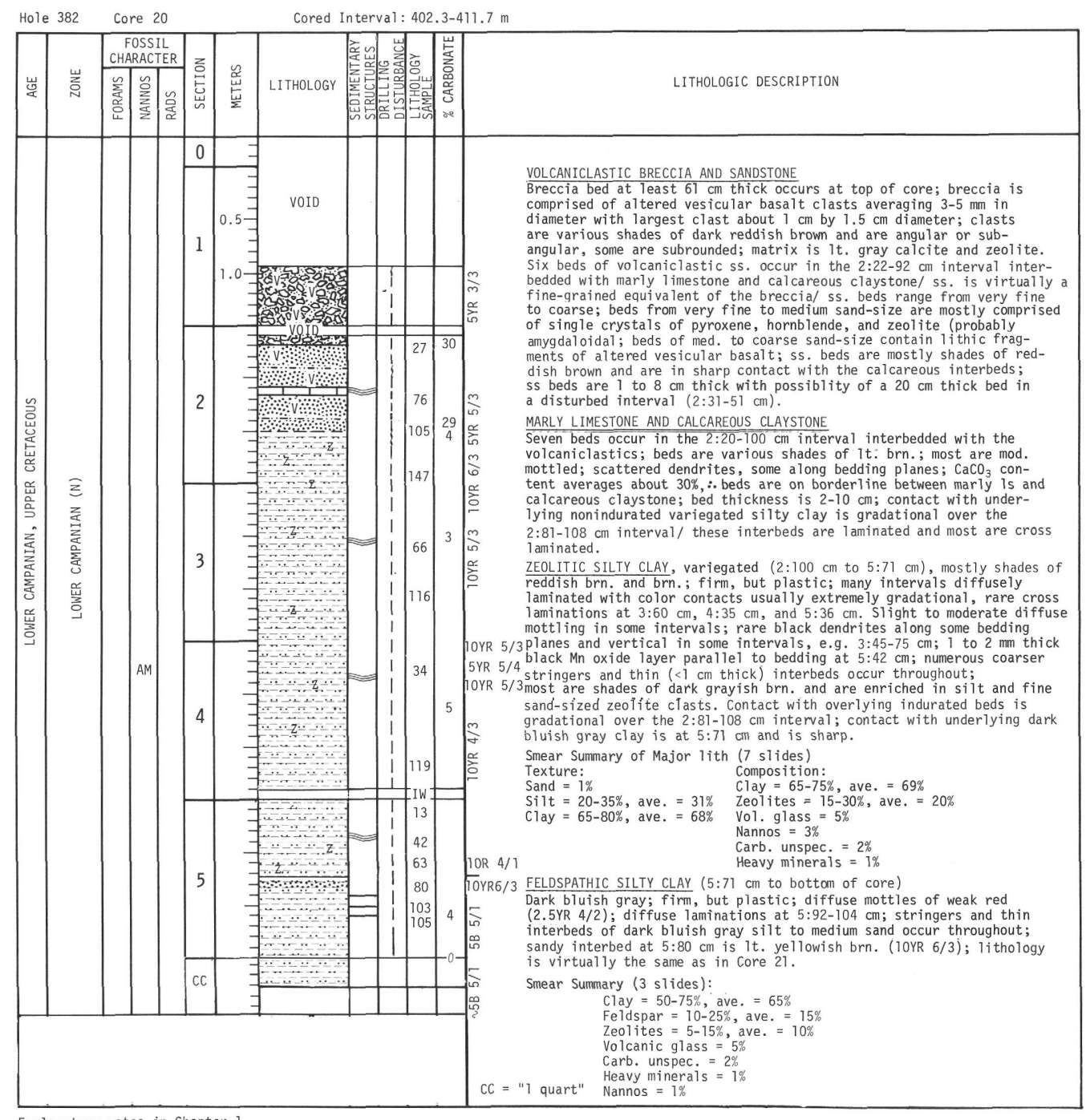

Explanatory notes in Chapter 1 


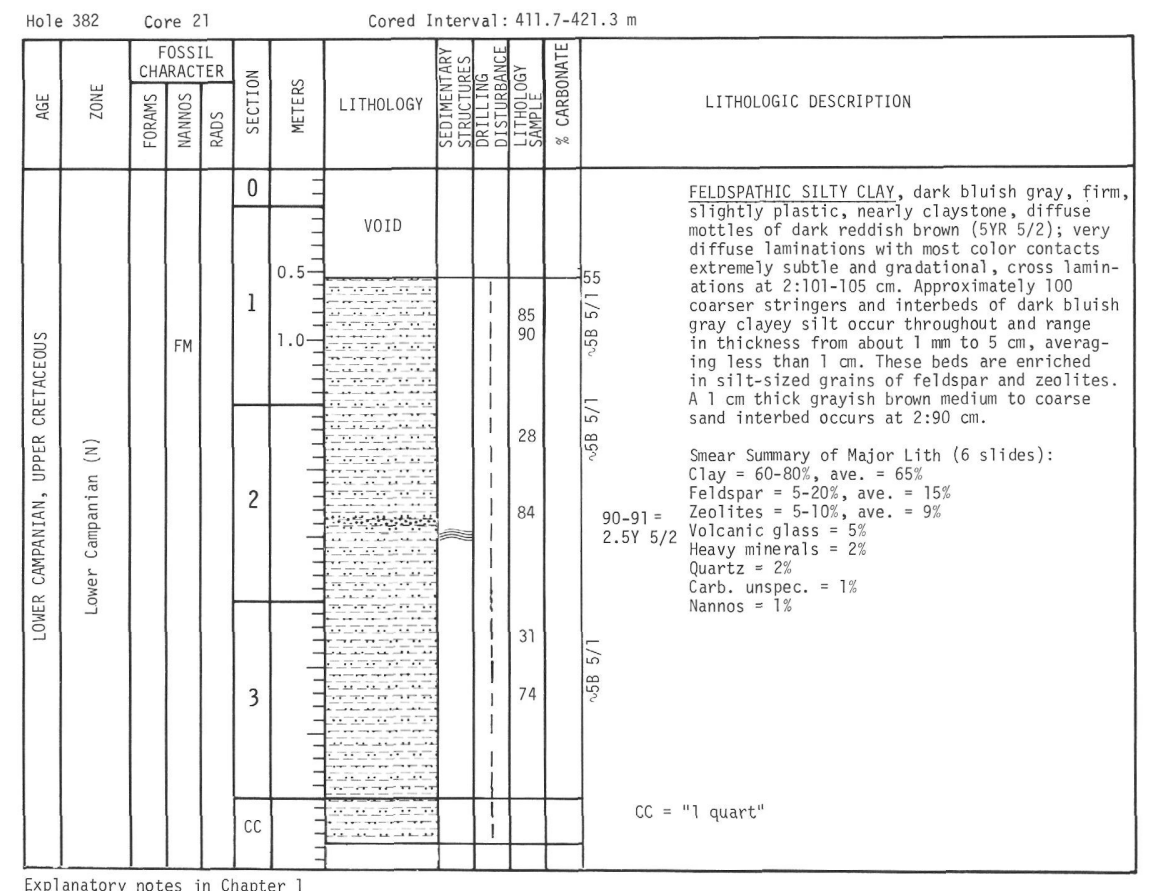

Explanatory notes in Chapter

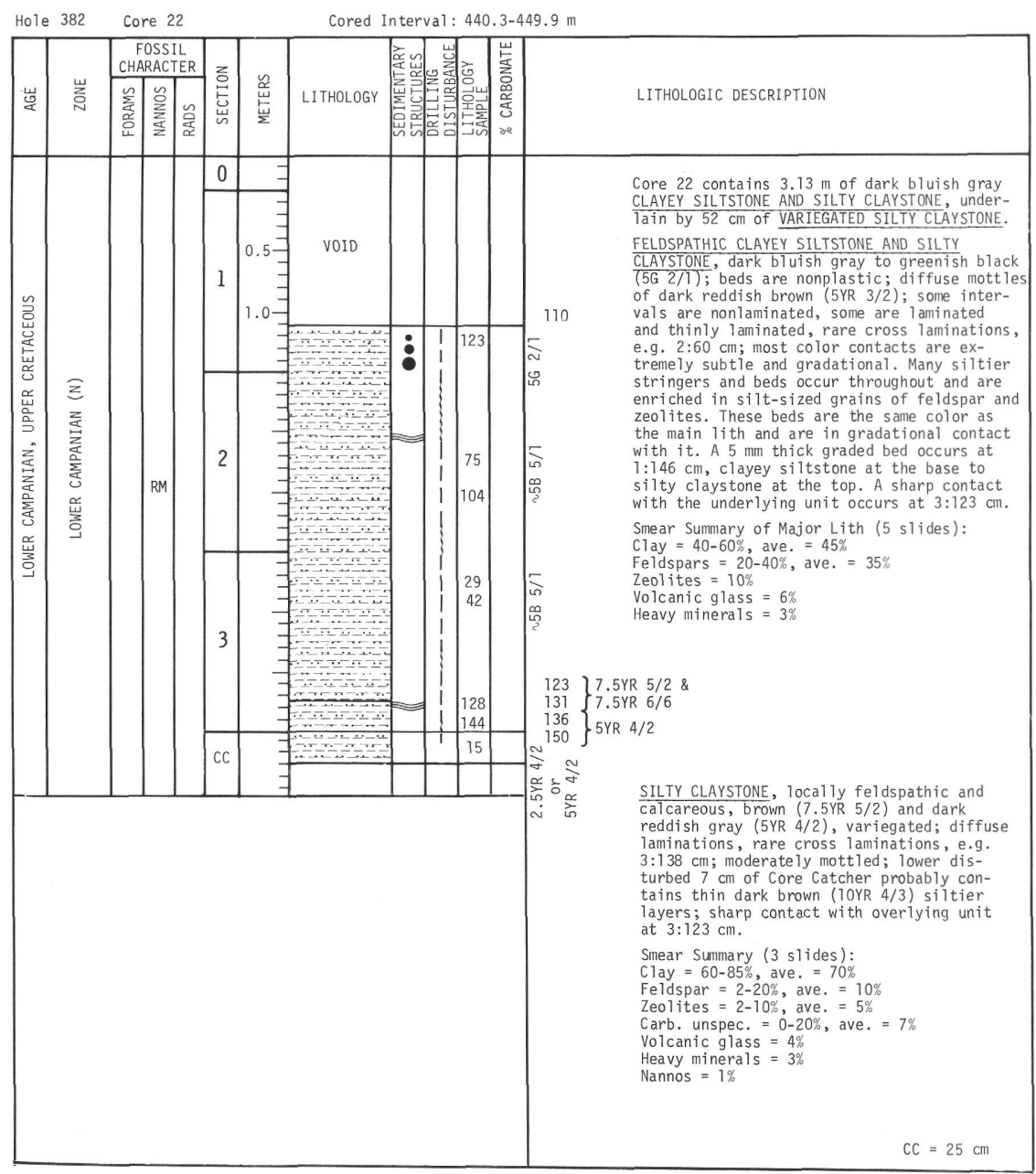




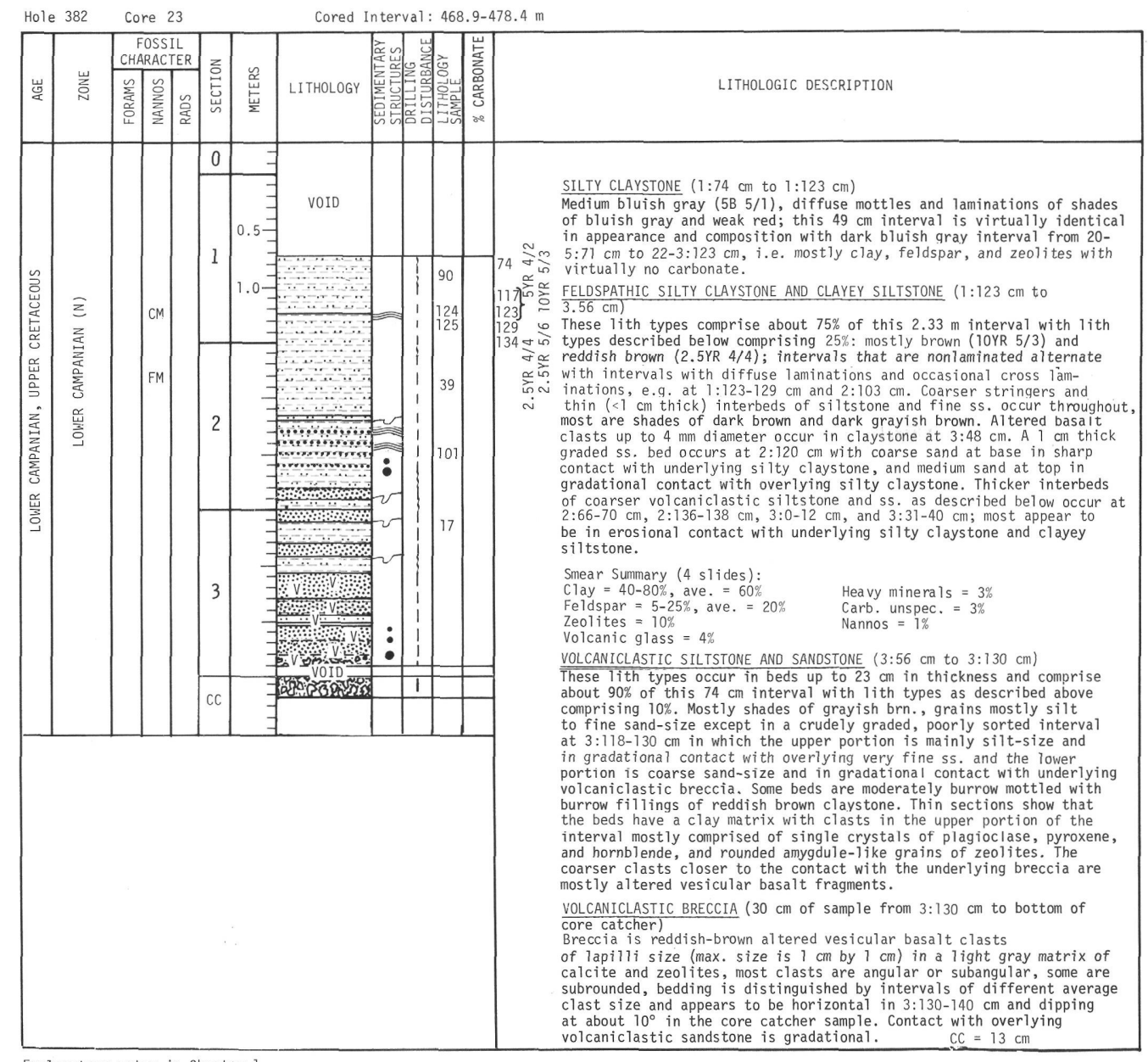

Explanatory notes in Chapter 1 

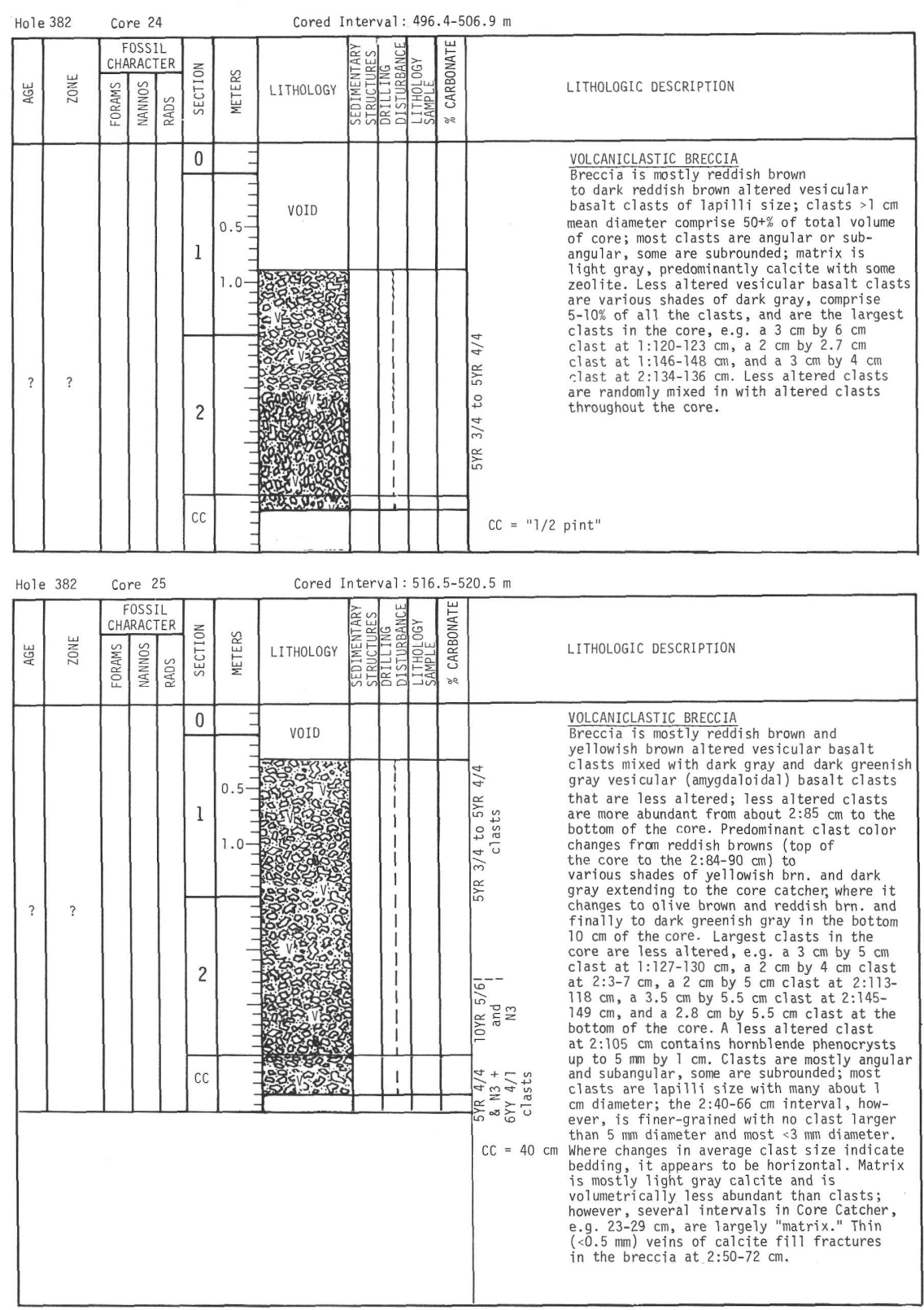

Explanatory notes in Chapter 1 


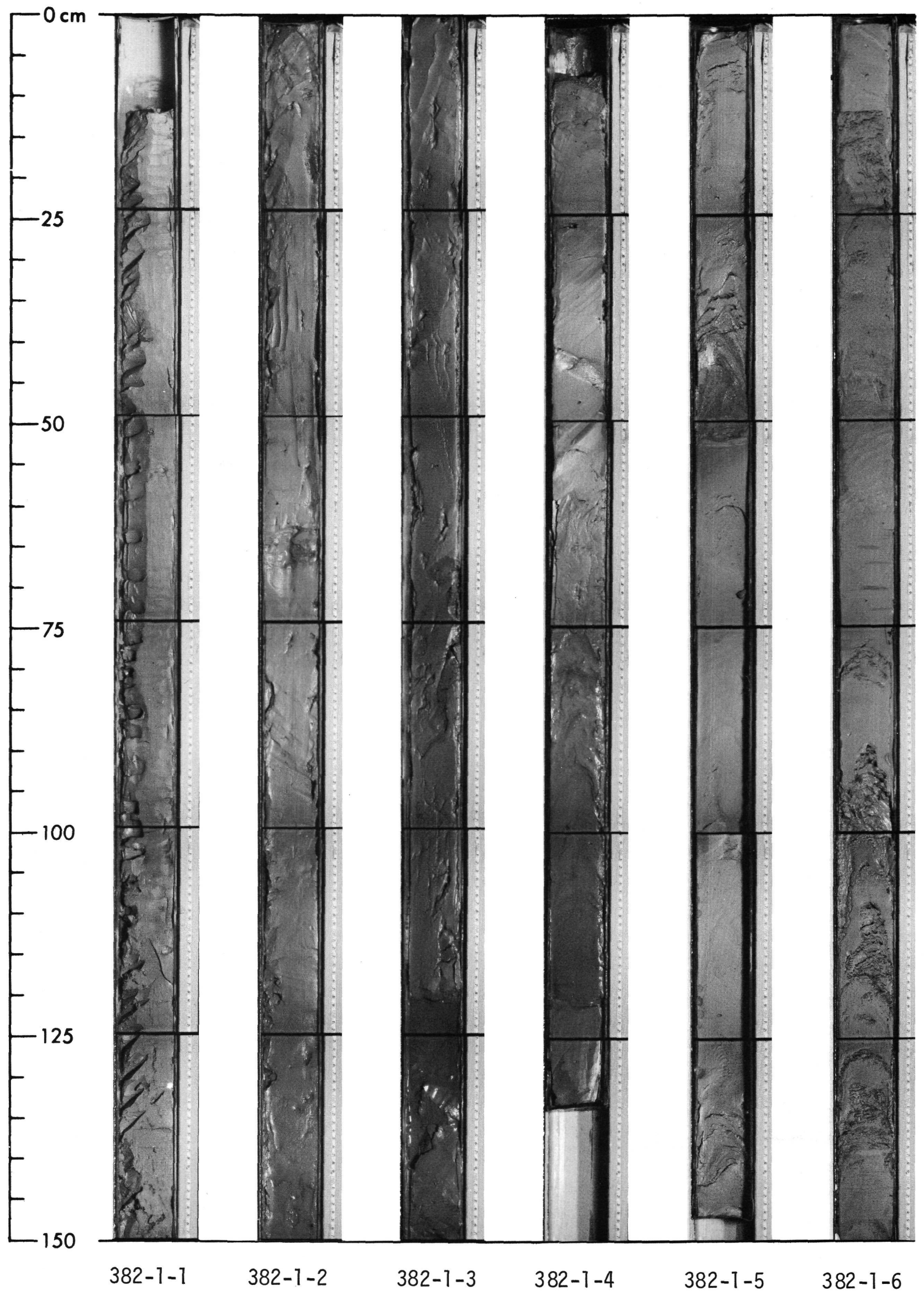




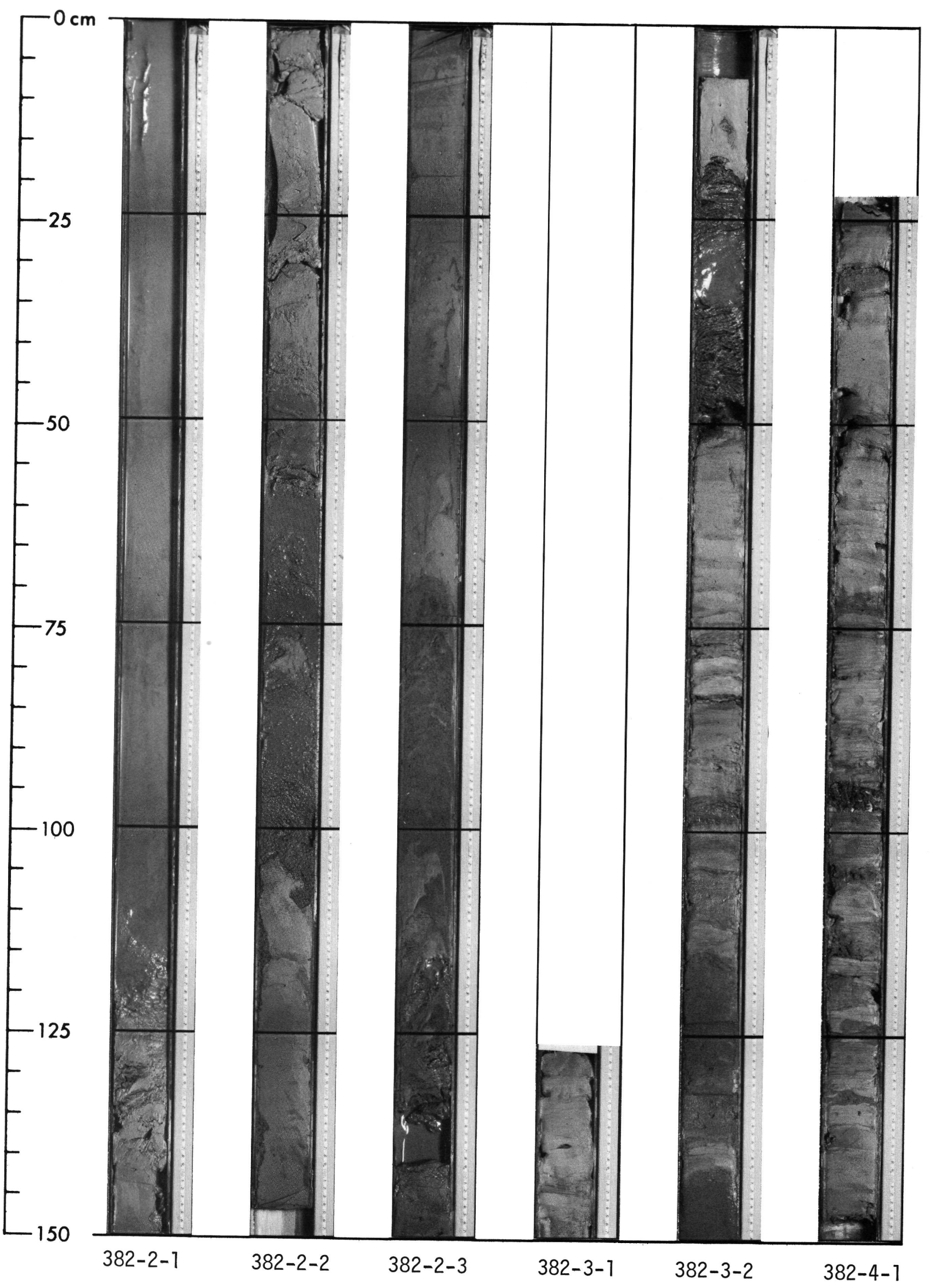




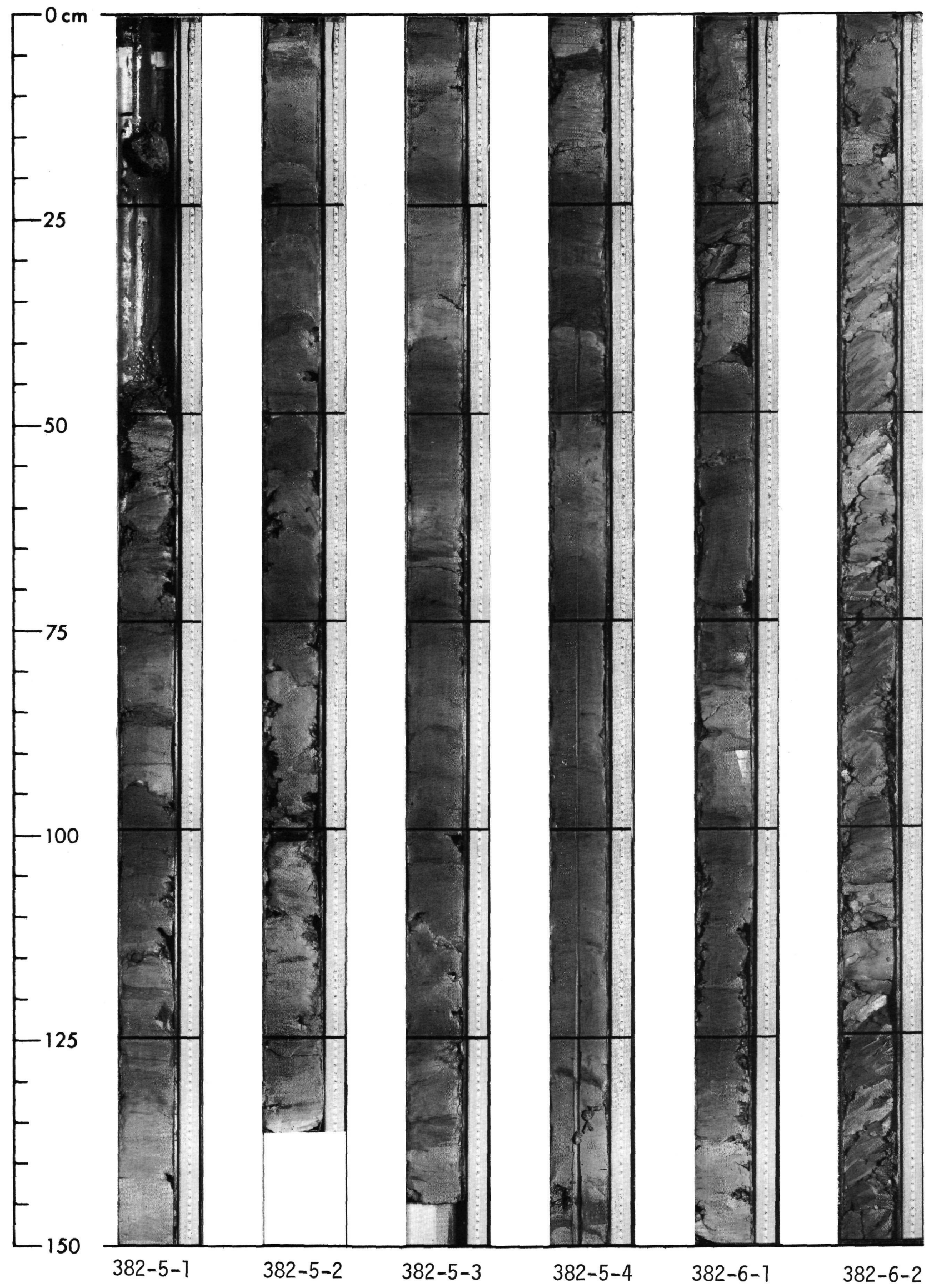




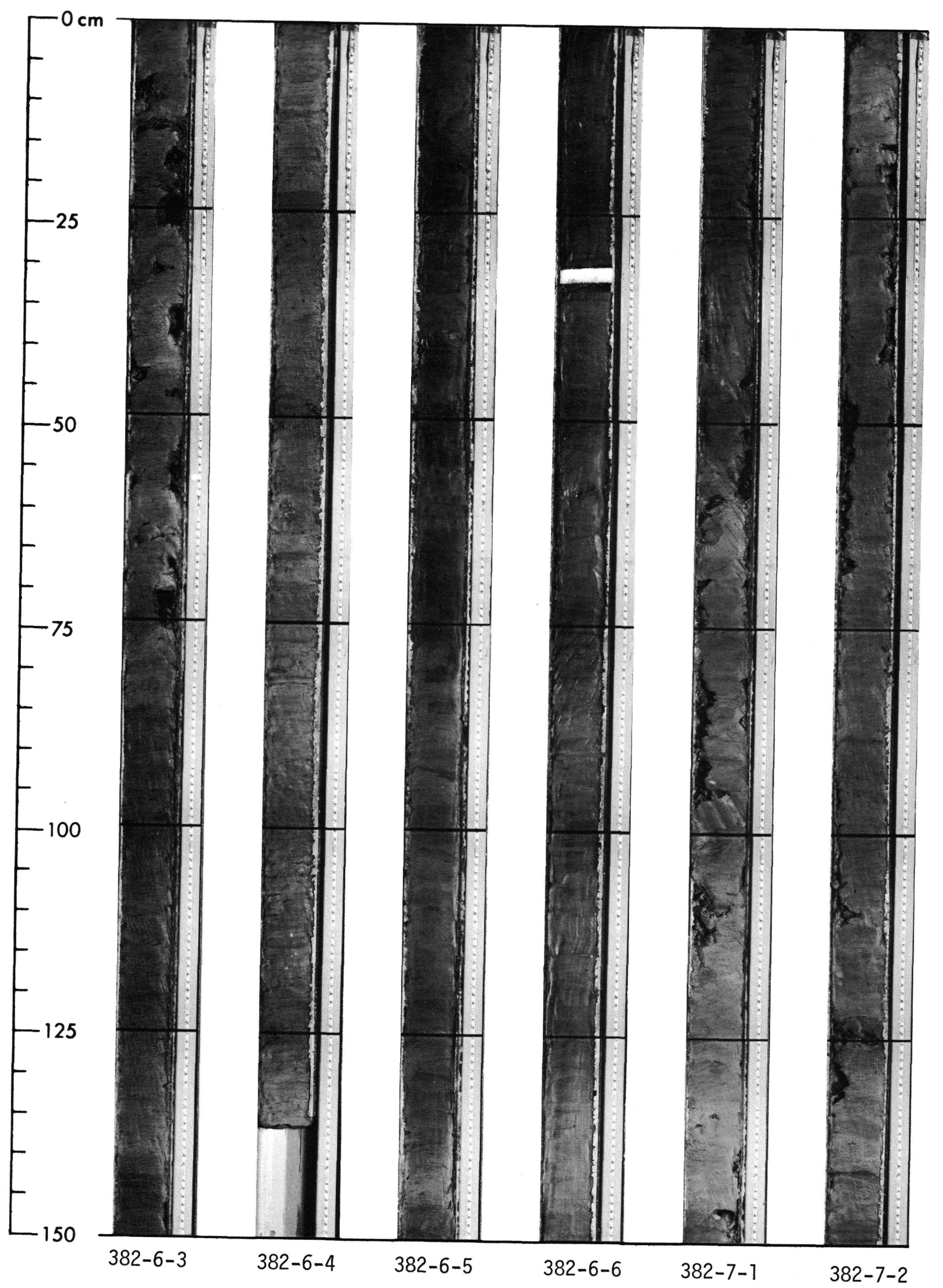




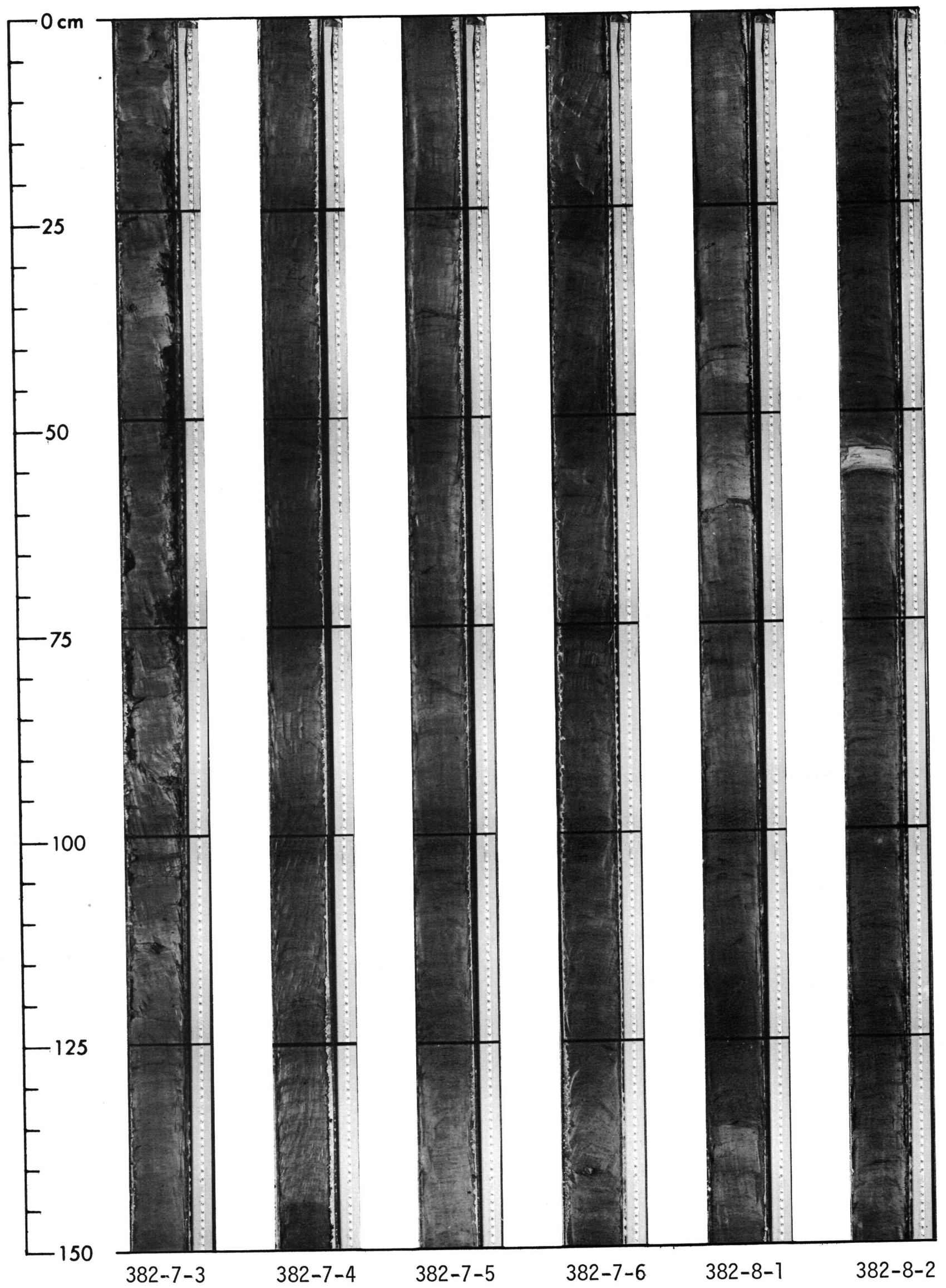




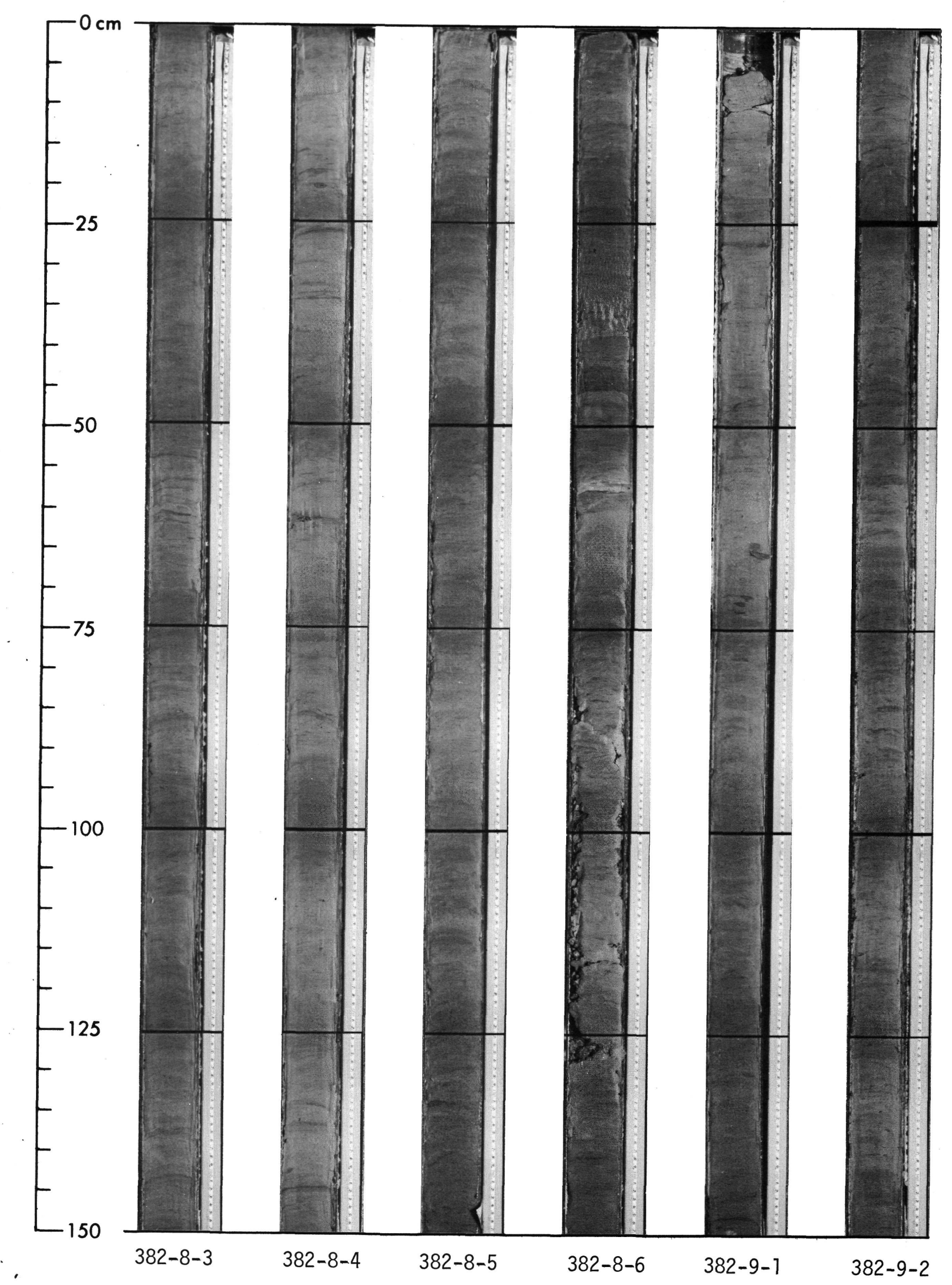




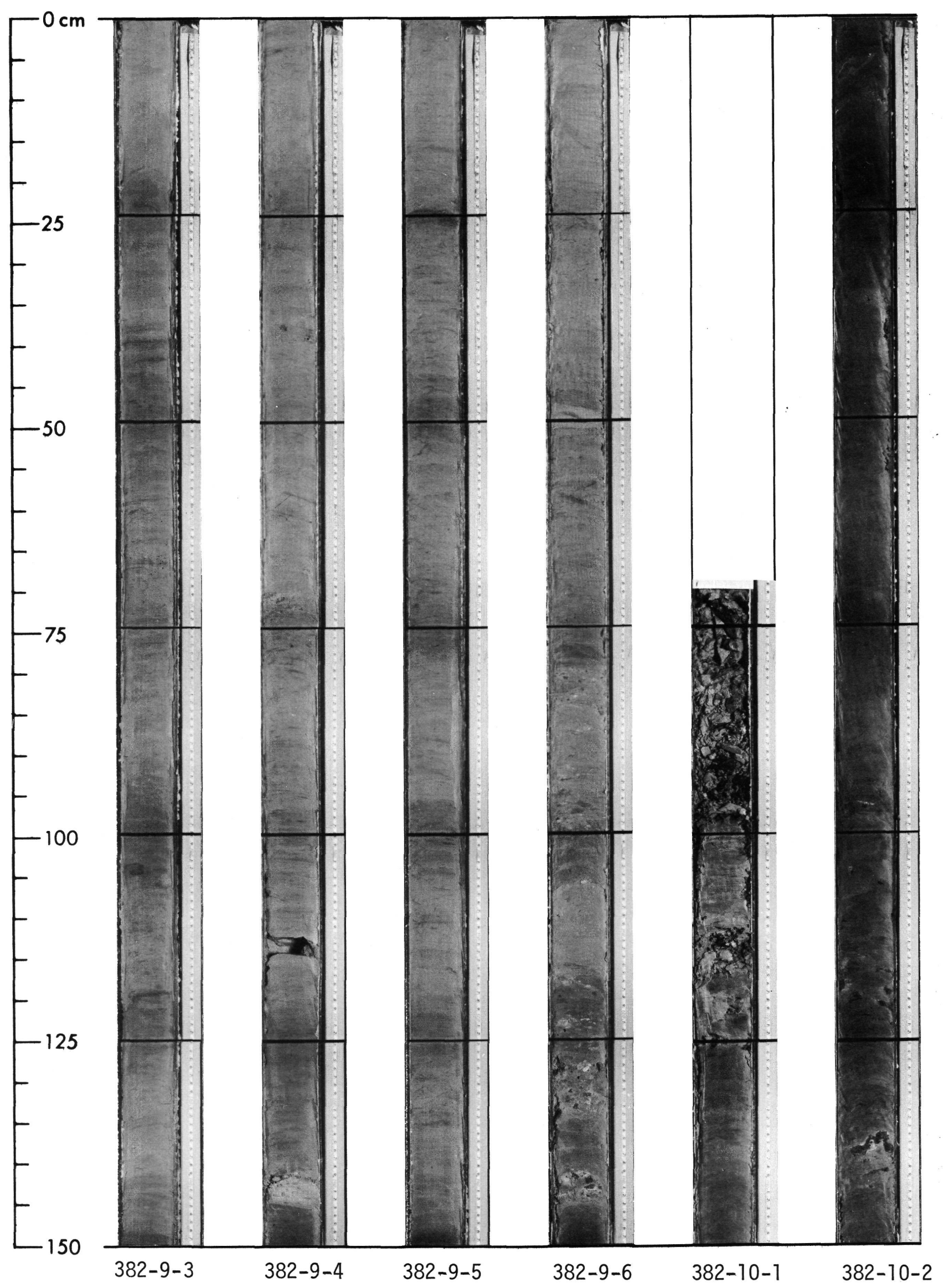




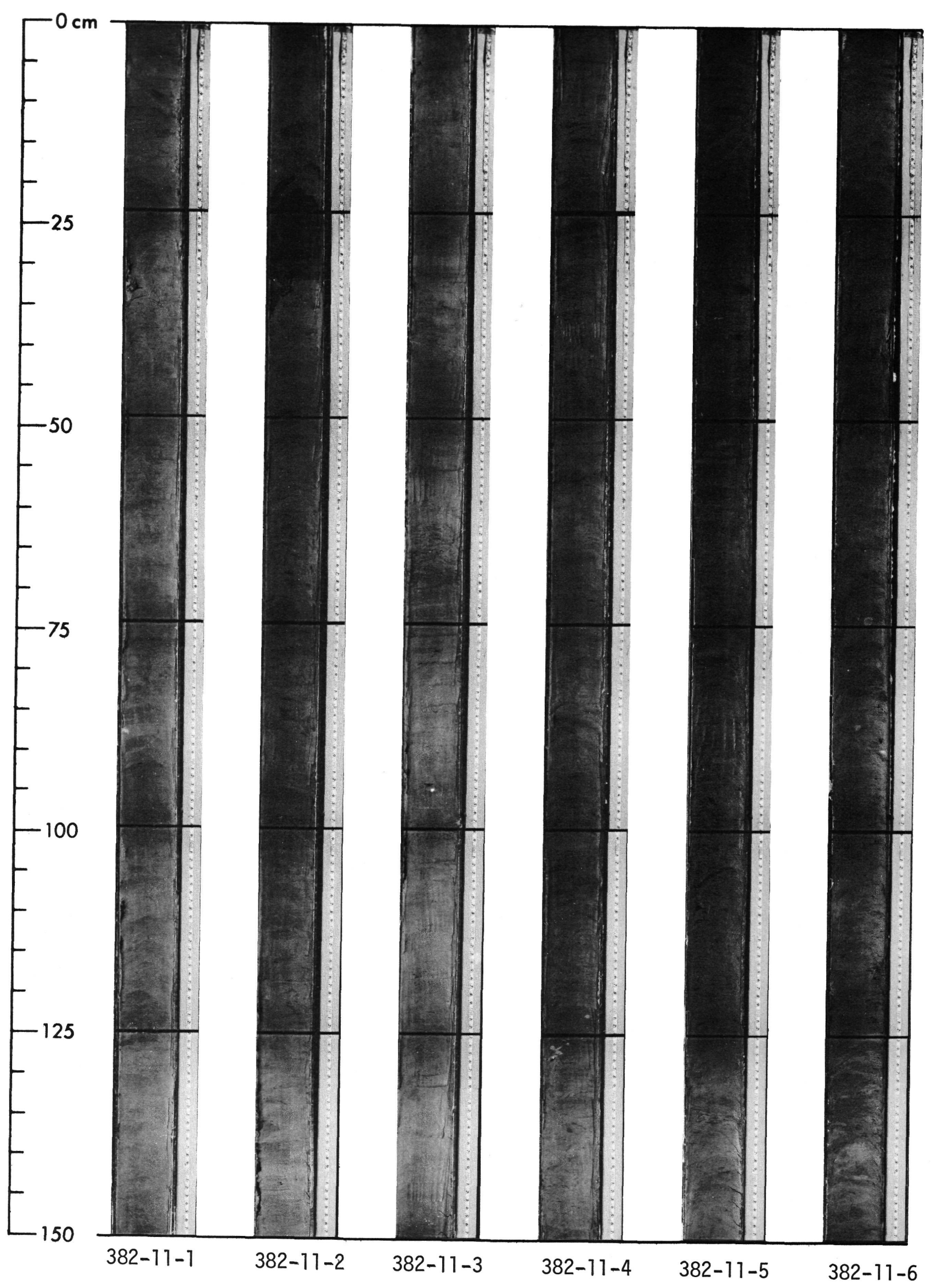




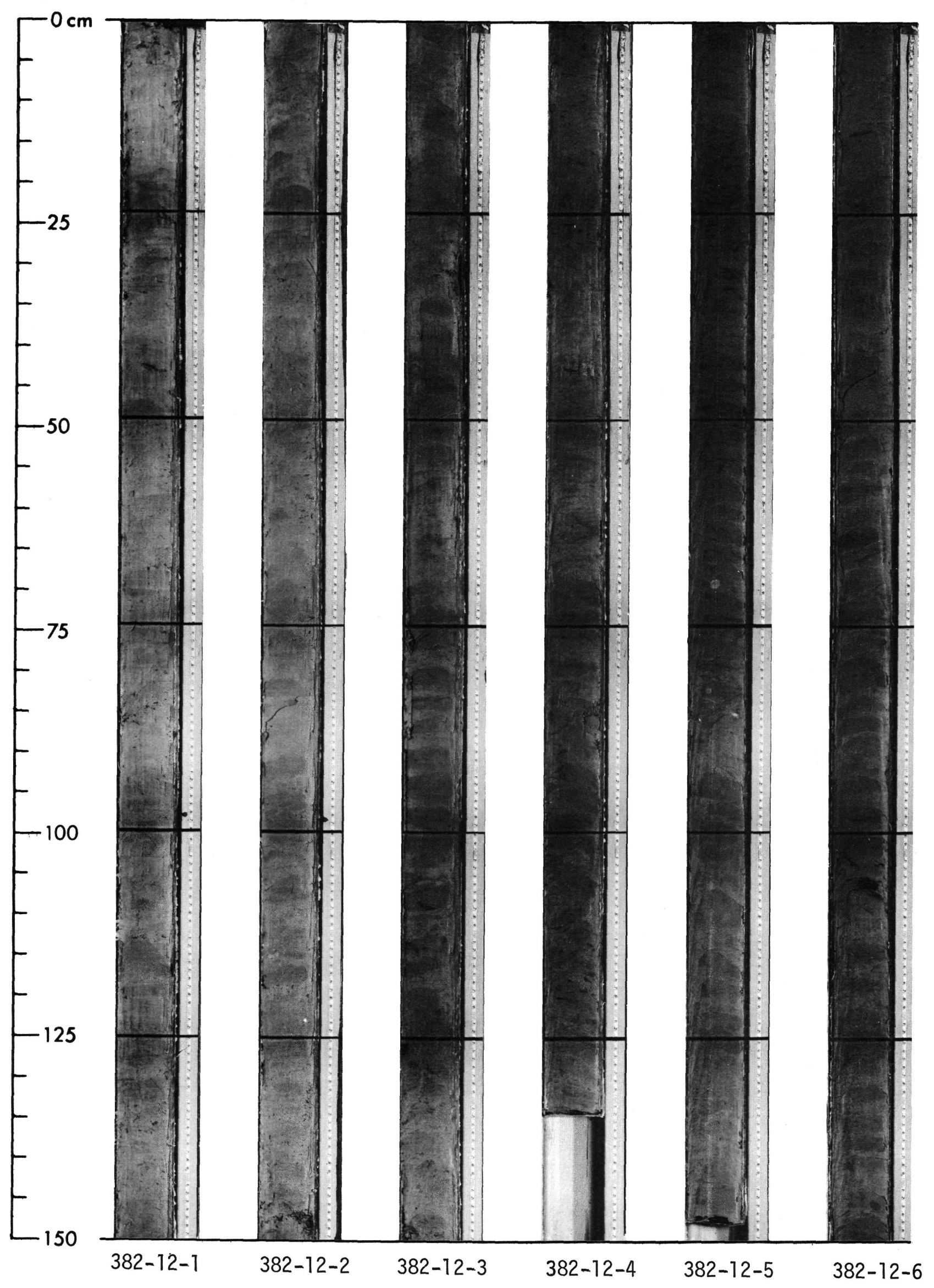




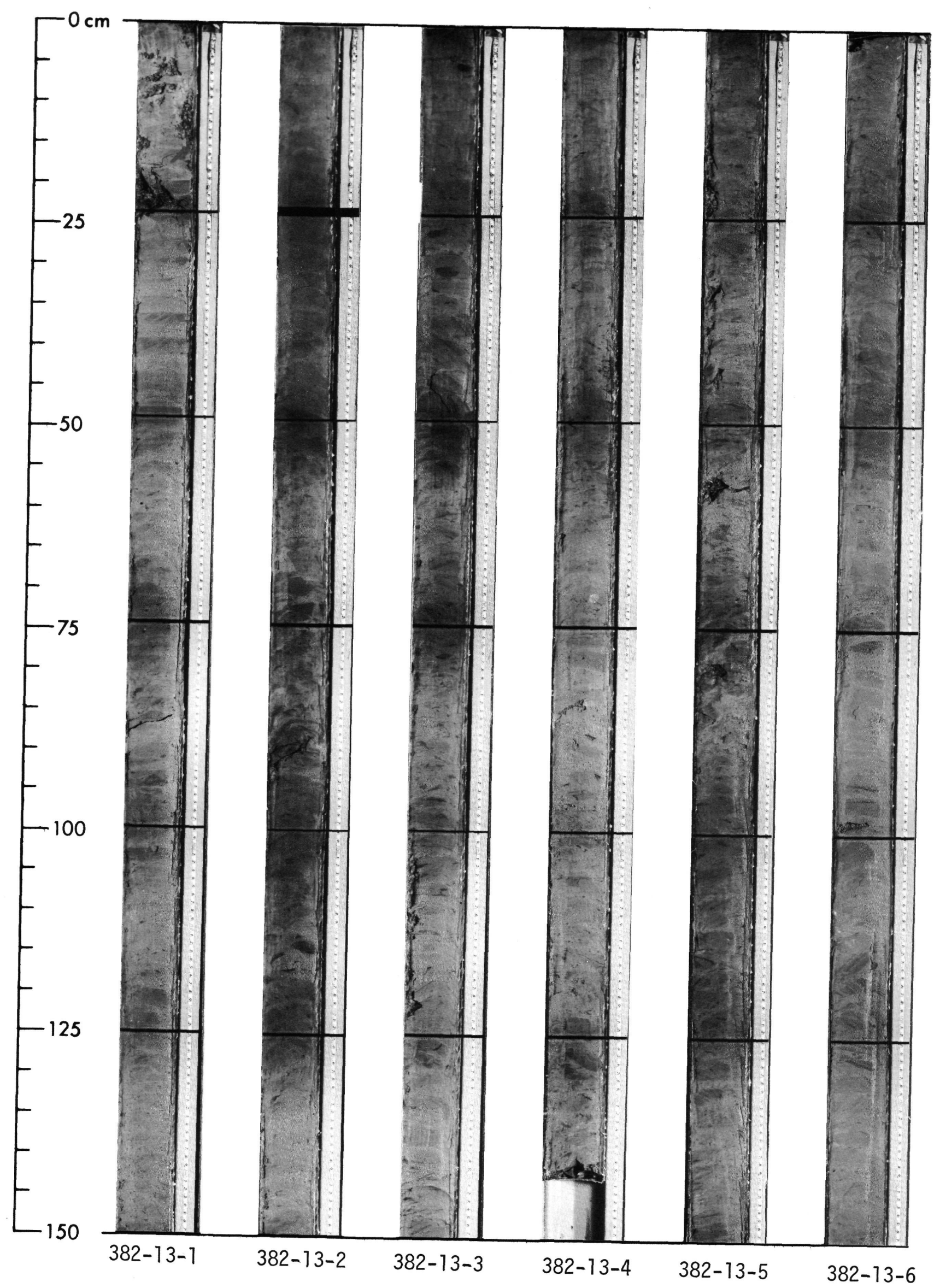




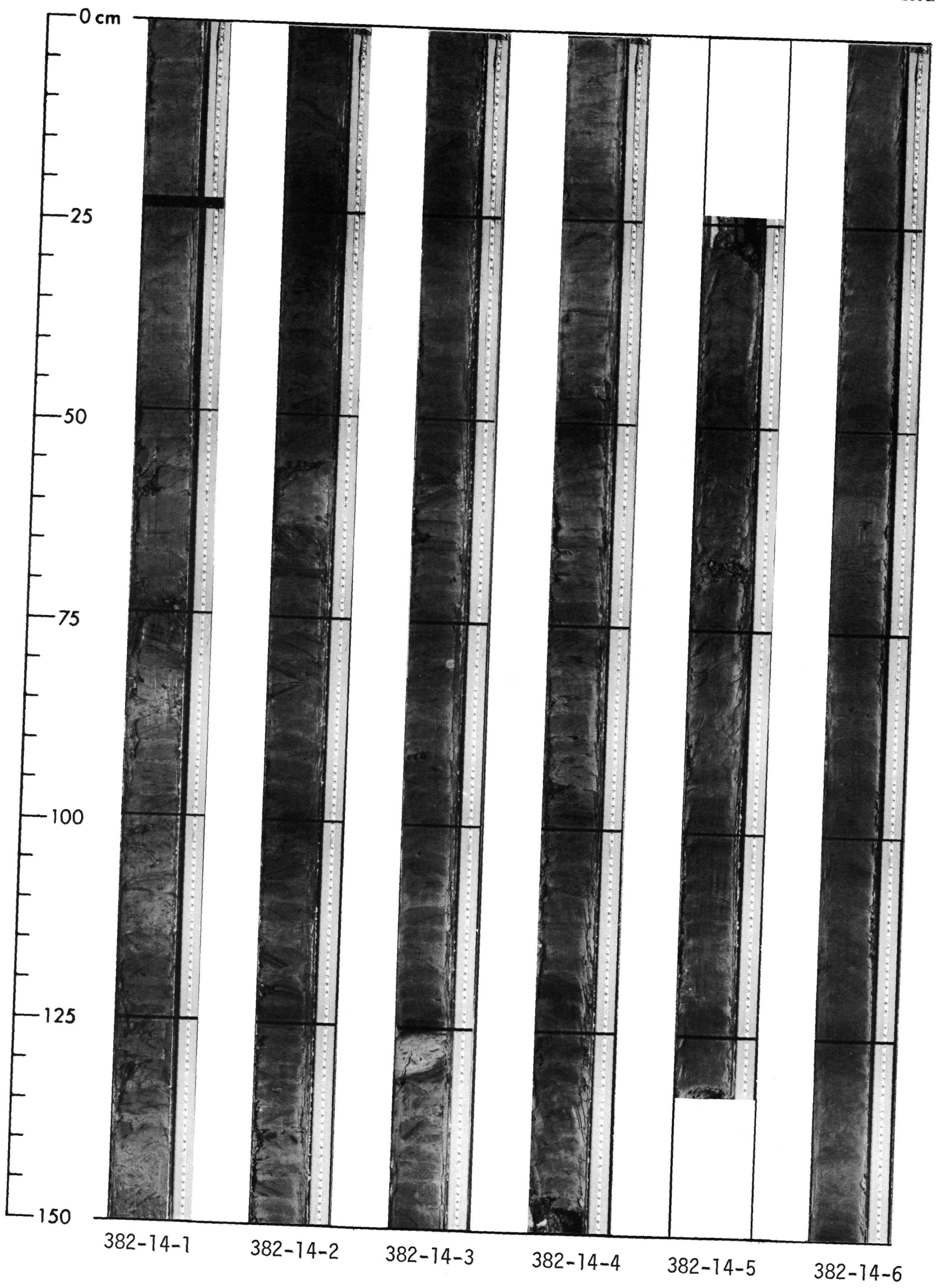




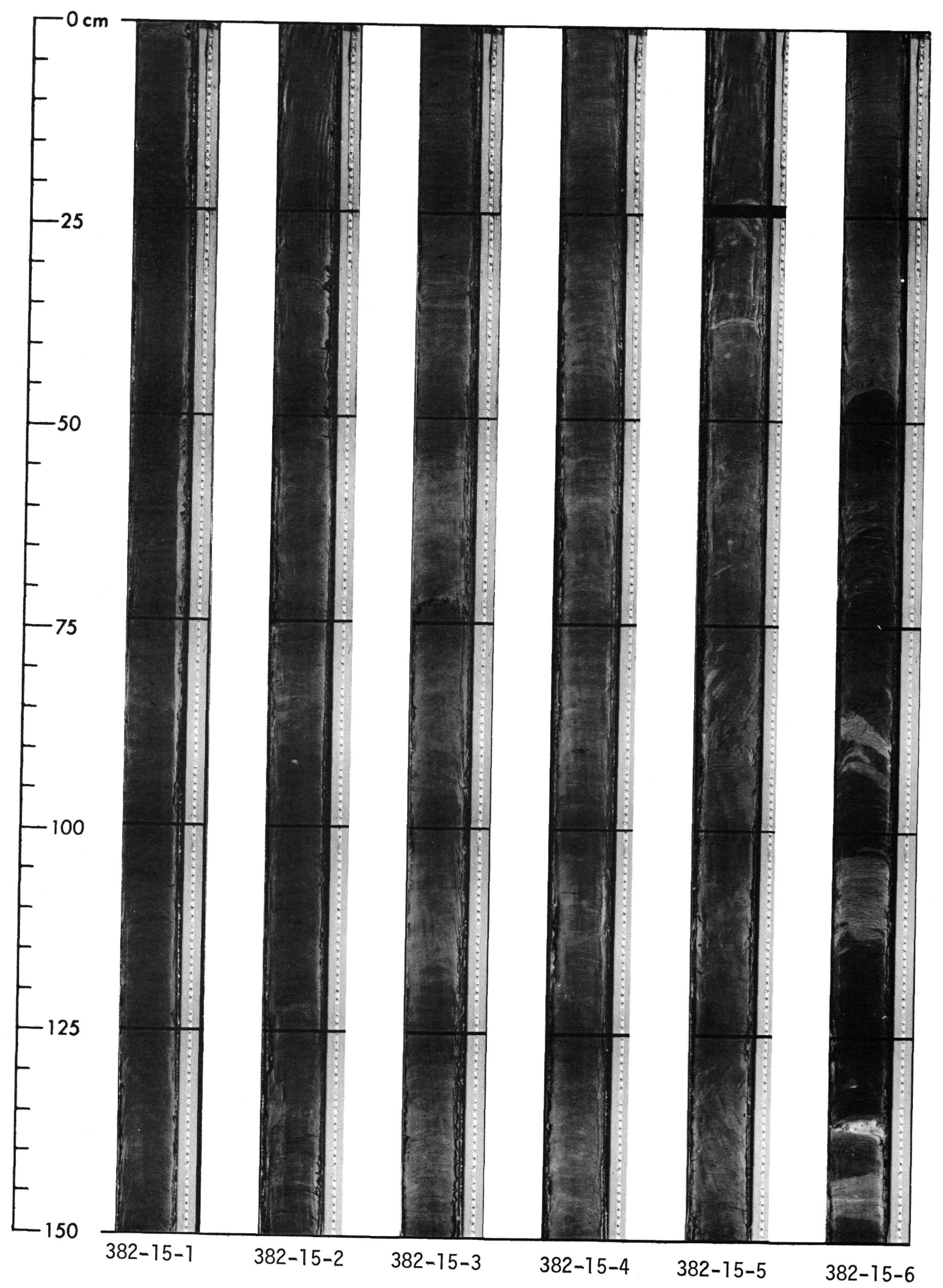




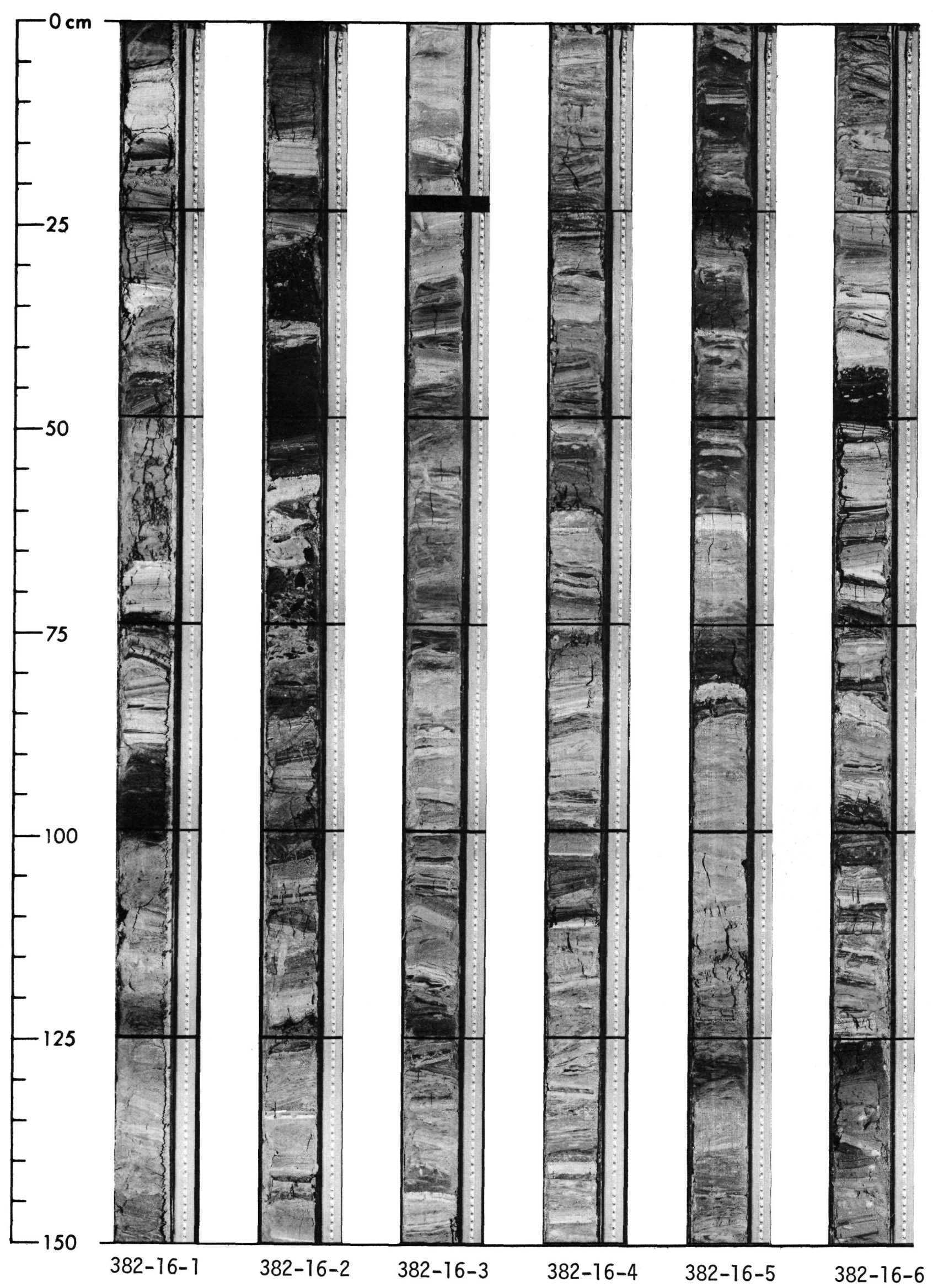




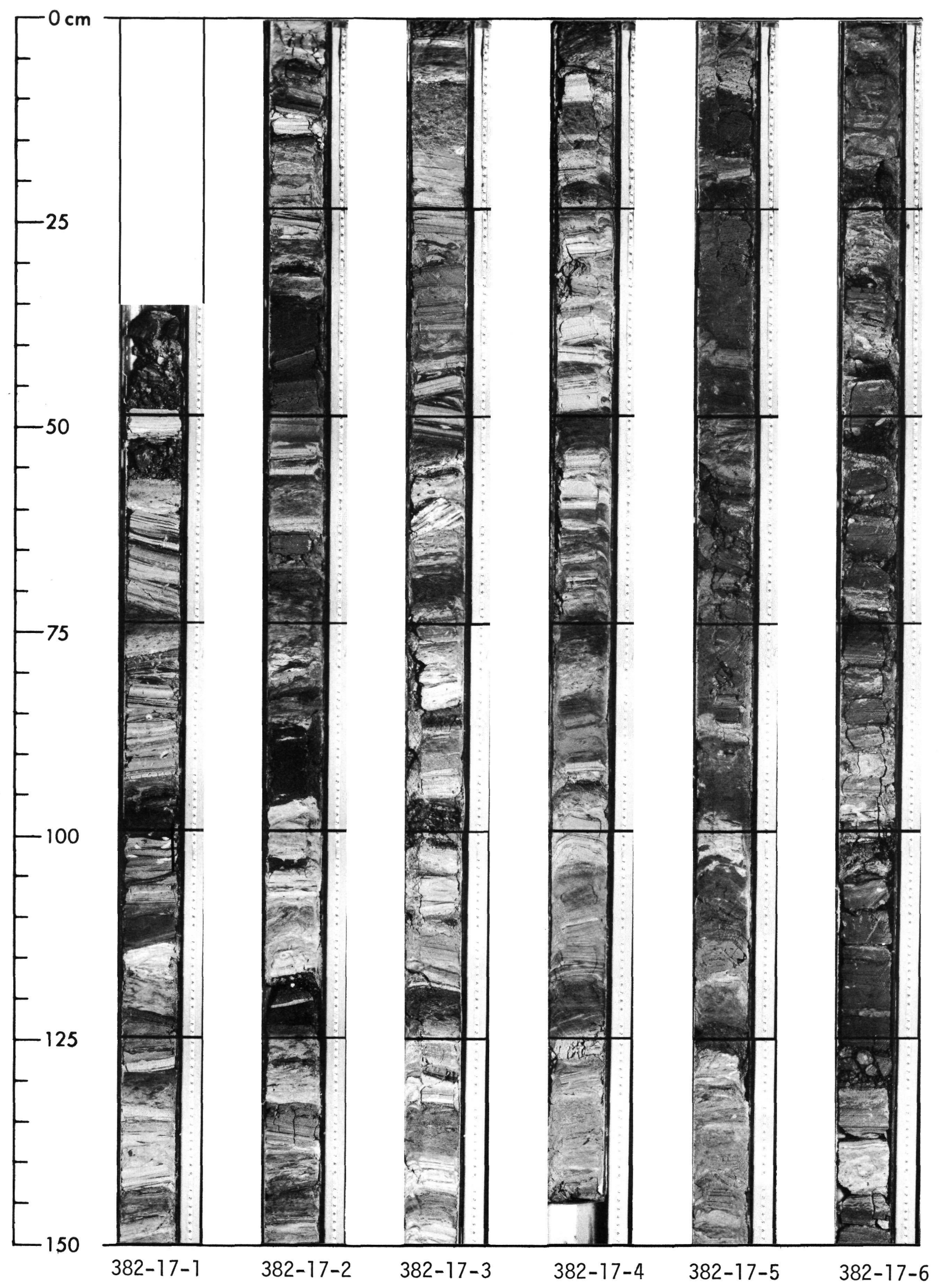




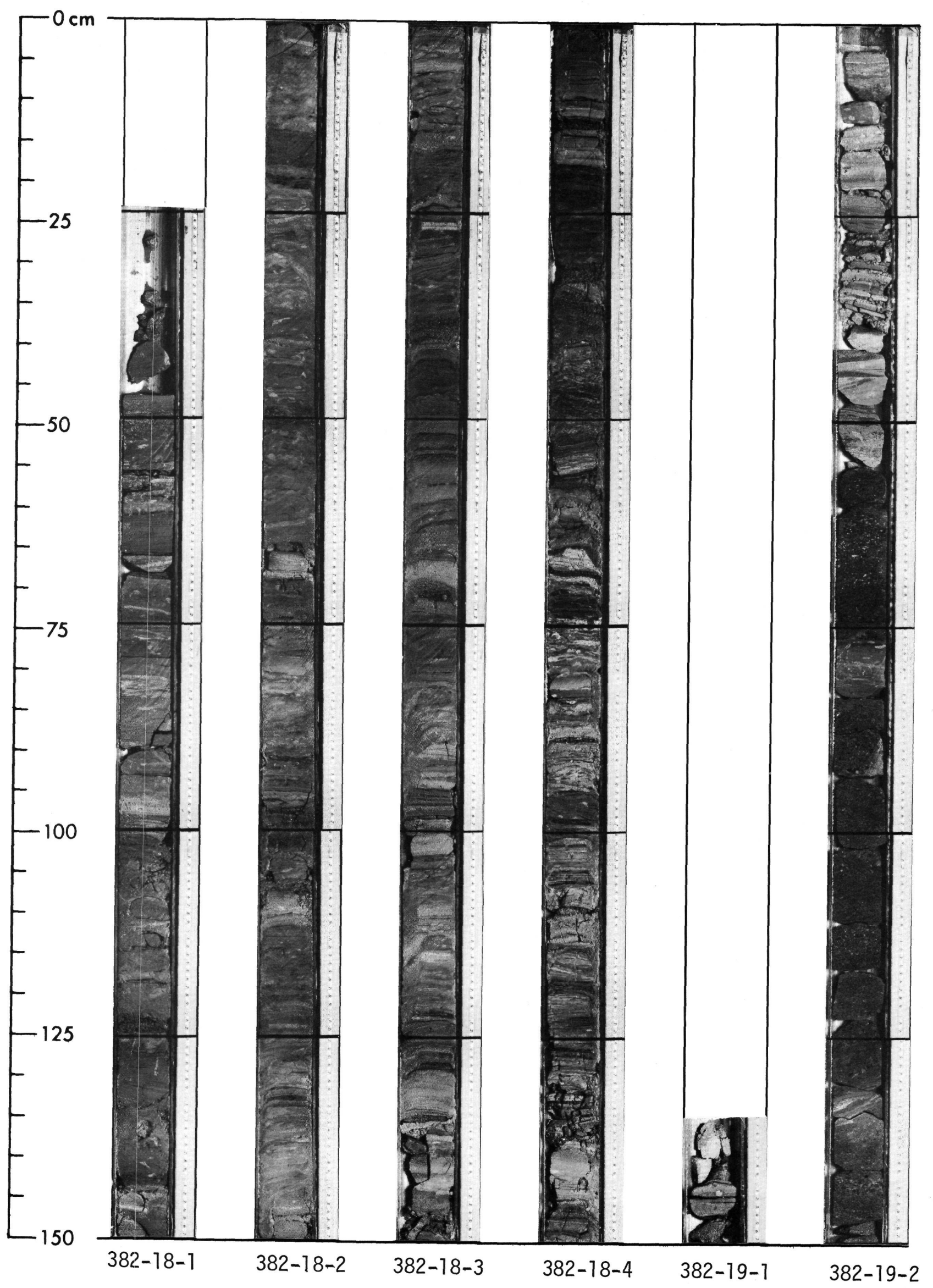




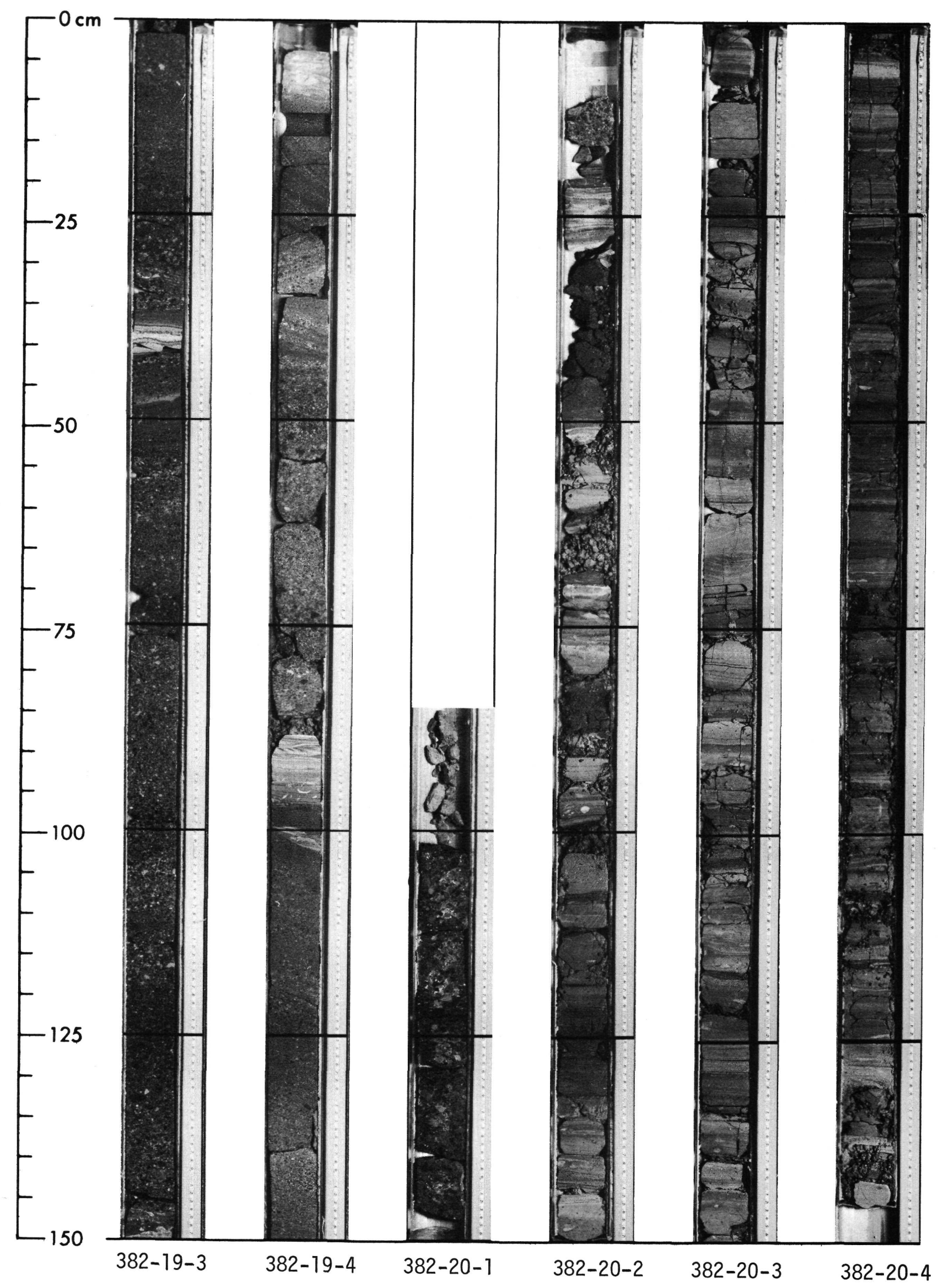




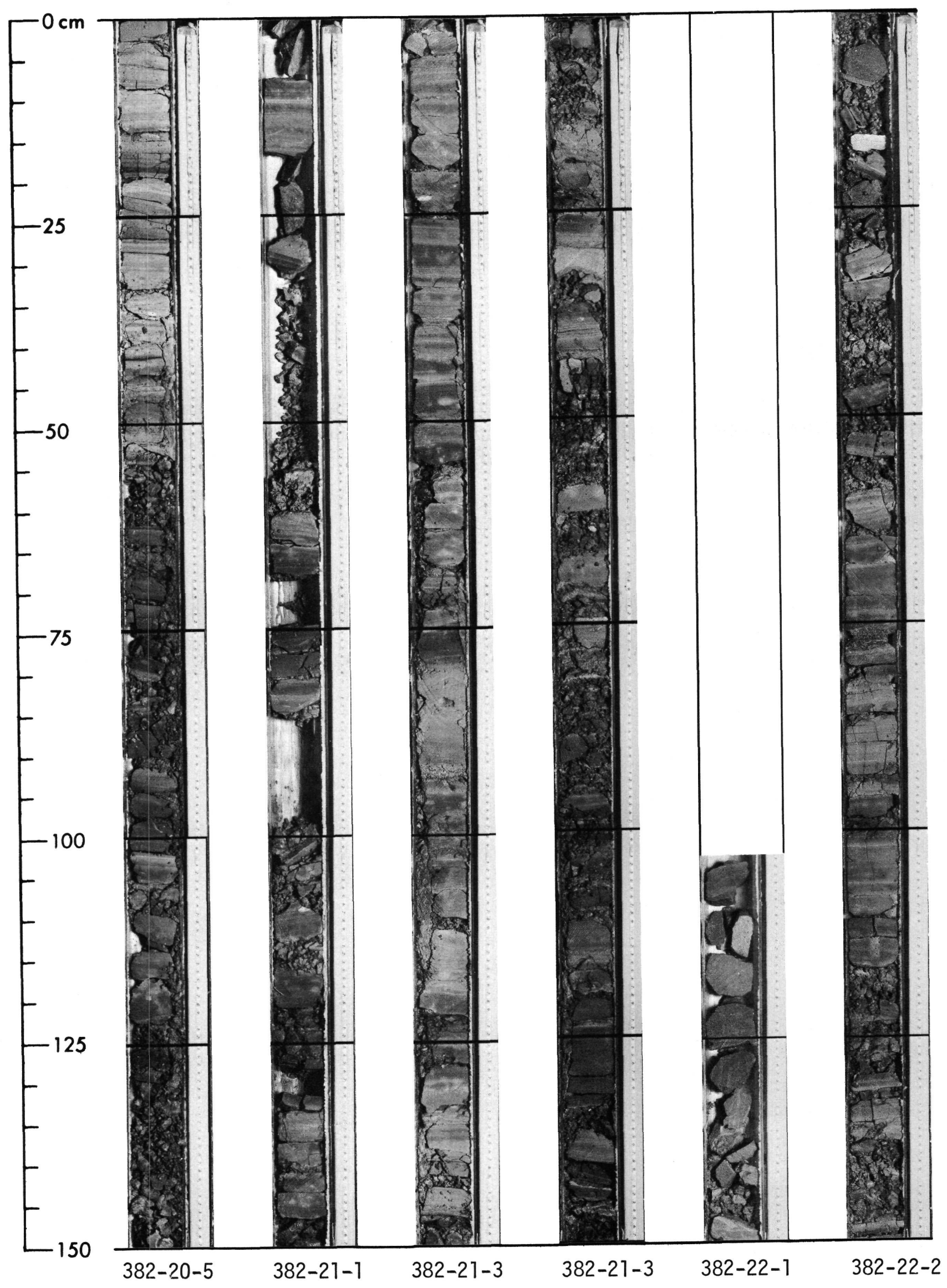




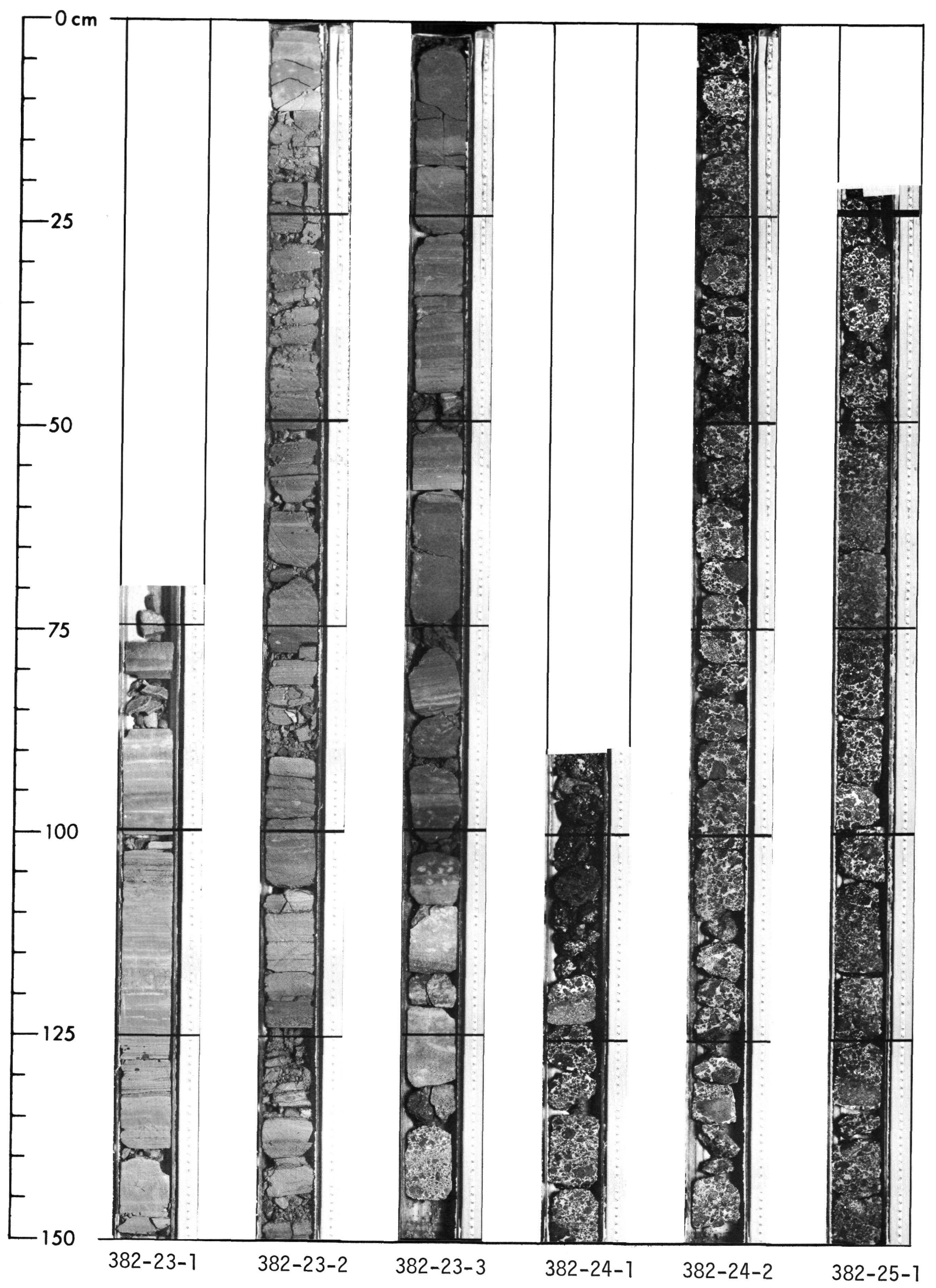




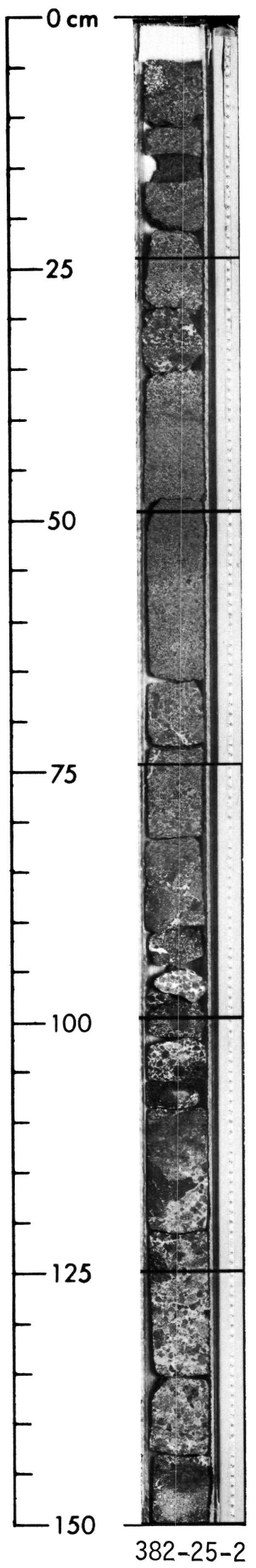

